ORNL/TM-13034

Dist. Category 902

Metals and Ceramics Division

\title{
A FACILITY DESIGN FOR REPACKAGING ORNL CH-TRU LEGACY WASTE IN BUILDING 3525
}

T. J. Huxford, R. H. Cooper, Jr., L. E. Davis, A. B. Fuller,* W. A. Gabbard, K. P. Guay, $\uparrow$ L. C. Smith, $\ddagger$ and R. B. Smith

Date Published: July 1995

\begin{abstract}
Prepared for
Department of Energy - Oak Ridge Operations Office Waste Management and Technology Development Division
\end{abstract}

\author{
Prepared by the \\ OAK RIDGE NATIONAL LABORATORY \\ Oak Ridge, Tennessee 37831 \\ managed by \\ LOCKHEED MARTIN ENERGY SYSTEMS \\ for the \\ U.S. DEPARTMENT OF ENERGY \\ under Contract DE-ACO5-84OR21400
}

\footnotetext{
* Consultant.

$\dagger$ S. M. Stoller Corp.

$\ddagger$ United Energy Services Corp.
} 


$$
\text { . }
$$




\section{DISCLAIMER}

This report was prepared as an account of work sponsored by an agency of the United States Government. Neither the United States Government nor any agency thereof, nor any of their employees, make any warranty, express or implied, or assumes any legal liability or responsibility for the accuracy, completeness, or usefulness of any information, apparatus, product, or process disclosed, or represents that its use would not infringe privately owned rights. Reference herein to any specific commercial product, process, or service by trade name, trademark, manufacturer, or otherwise does not necessarily constitute or imply its endorsement, recommendation, or favoring by the United States Government or any agency thereof. The views and opinions of authors expressed herein do not necessarily state or reflect those of the United States Government or any agency thereof. 


\section{DISCLAIMER}

Portions of this document may be illegible in electronic image products. Images are produced from the best available original document. 


\section{CONTENTS}

Page

LIST OF TABLES $\ldots \ldots \ldots \ldots \ldots \ldots \ldots \ldots \ldots \ldots \ldots \ldots \ldots \ldots \ldots \ldots$

LIST OF FIGURES $\ldots \ldots \ldots \ldots \ldots \ldots \ldots \ldots \ldots \ldots \ldots \ldots \ldots \ldots$ vii

LIST OF ACRONYMS $\ldots \ldots \ldots \ldots \ldots \ldots \ldots \ldots \ldots \ldots \ldots \ldots \ldots \ldots \ldots \ldots$

EXECUTIVE SUMMARY $\ldots \ldots \ldots \ldots \ldots \ldots \ldots \ldots \ldots \ldots \ldots \ldots \ldots \ldots \ldots$

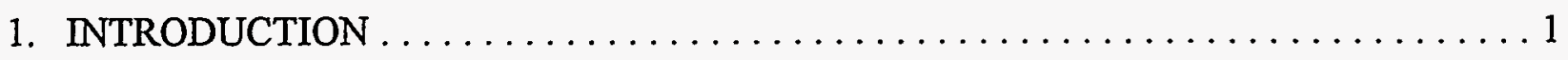

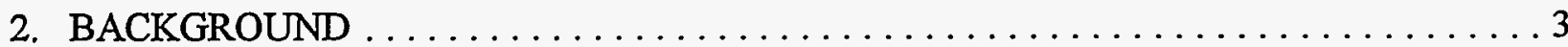

2.1 GLOVE BOX REFERENCE DESIGN $\ldots \ldots \ldots \ldots \ldots \ldots \ldots \ldots \ldots \ldots \ldots$

2.2 BENCHMARKING THE REFERENCE DESIGN . . . . . . . . . . . . . 7

2.3 REFORMULATION OF THE APRI 1994 REFERENCE DESIGN . . . . . . . . . 11

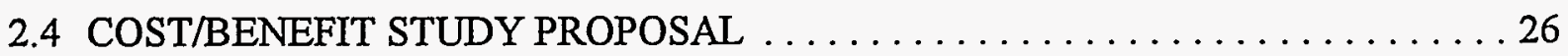

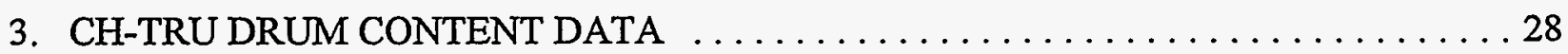

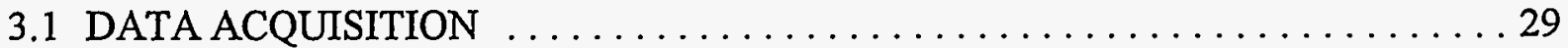

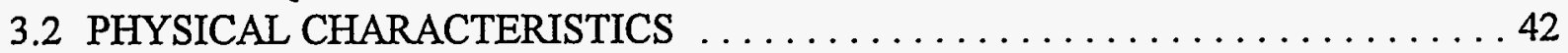

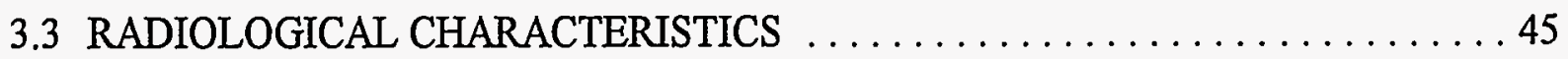

3.3.1 External Surface Dose Rate Data From WEAF . . . . . . . . . . . . . . . 46

3.3.2 CH-TRU Drums in the SWIMS Data Base Sorted by External

Surface Dose Rate Data from RCRA Closure Evaluation . . . . . . . . . . . 46

3.3.3 CH-TRU drums in the SWIMS Inventory Database by

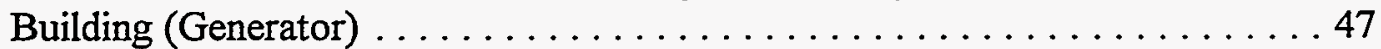

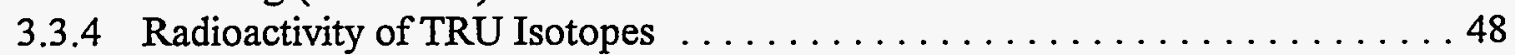

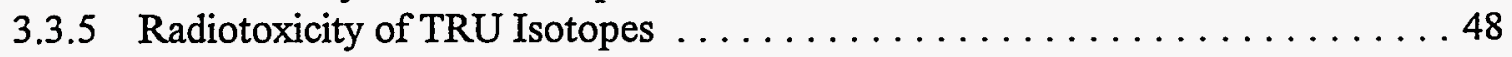

3.3.6 Dose Calculation Data for TRU Isotopes . . . . . . . . . . . . . . . 49

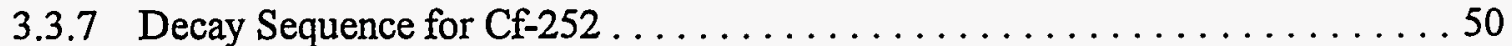

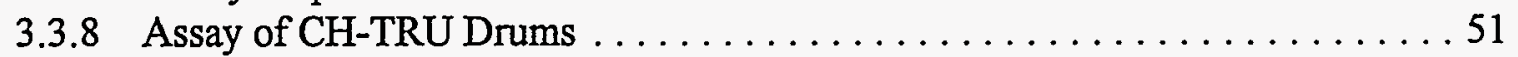

3.3 .9 Neutron Emission Rate . . . . . . . . . . . . . . . . . . . 52

3.3.10 TRU Radioisotopes in CH-TRU Drums as Listed in the

SWIMS Data Base . . . . . . . . . . . . . . . . . . 52

3.3.11 CH-TRU Drum Selection Criteria and Selected Drums for

Consideration as Candidates for Initial Repackaging . . . . . . . . . . . . 54 
4. CHARACTERIZATION AND CERTIFICATION TO THE WIPP-WAC . . . . . . 54

4.1 NATIONAL TRU WASTE CHARACTERIZATION PROGRAM . . . . . . . . 54

4.2 ORNL TRU WASTE CHARACTERIZATION/CERTIFICATION $\ldots \ldots \ldots \ldots 58$

5. RECOMMENDED DESIGN FOR PHASED GLOVE BOX ENCLOSURE $\ldots \ldots \ldots \ldots 63$

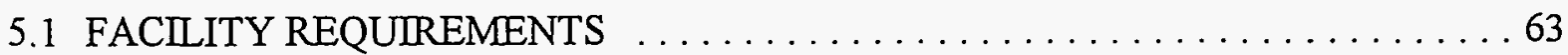

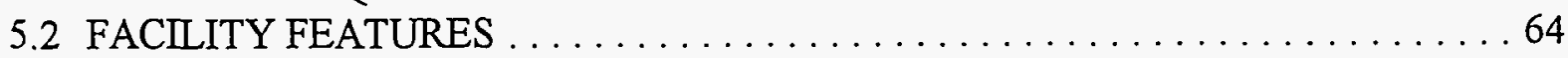

5.3 HEATING, VENTILATION, AND AIR CONDITIONING . . . . . . . . 83

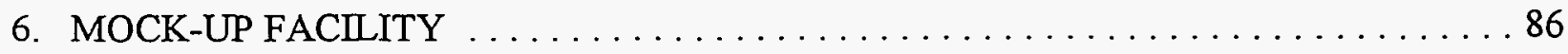

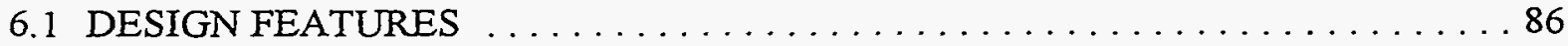

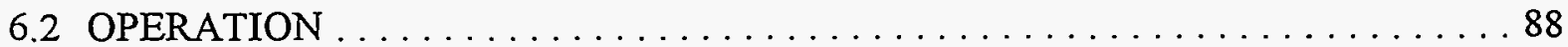

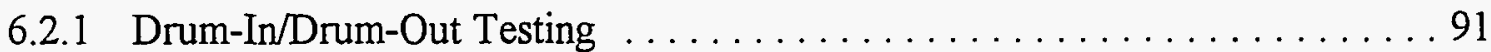

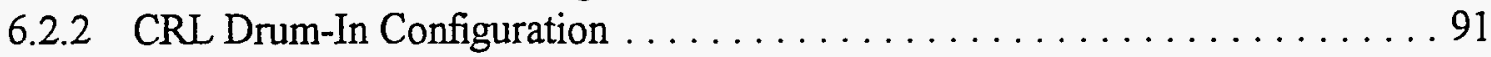

6.2.3 CRL Drum-In Procedure ........................... 91

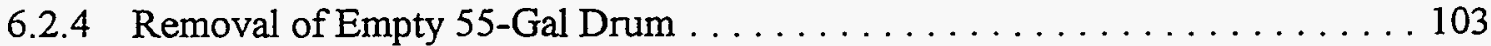

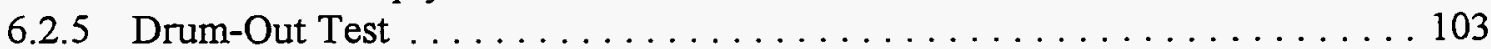

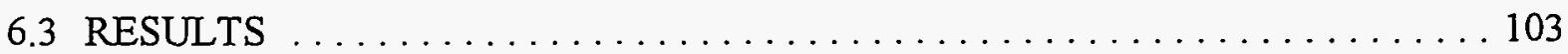

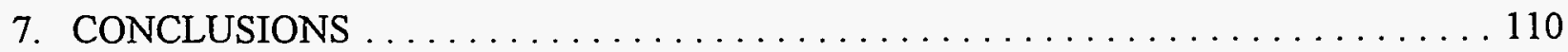

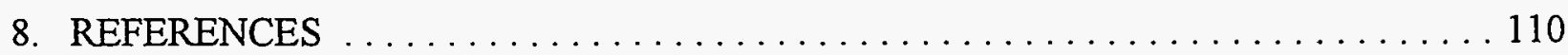

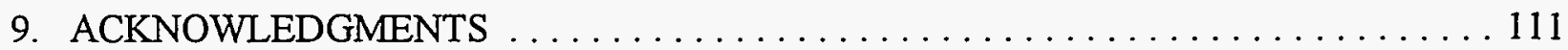




\section{LIST OF TABLES}

Table

$\underline{\text { Page }}$

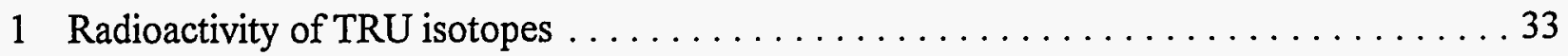

2 Radioactivity guidelines from the $\mathrm{ORNL}$ health physics procedure $\ldots \ldots \ldots \ldots \ldots 34$

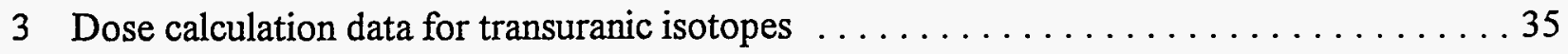

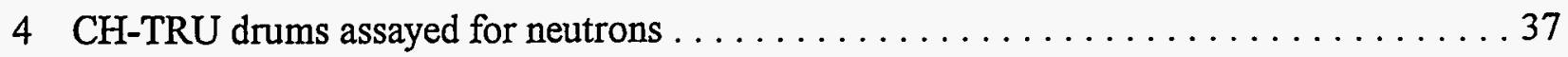

5 Average yearly maximum permissible neutron flux to meet ALARA goals of $500 \mathrm{mrem} /$ year for a 1254 hour work year . . . . . . . . . . . . . . . . . 38

6 Transuranic radioisotopes in CH-TRU drums as listed in the SWIMS data base . . . . . . 39

7 CH-TRU drum selection criteria and selected drums for consideration for initial repackaging

8 Work breakdown structure for the design, fabrication, and installation of the March 1995 reference design basic CH-TRU glove box option to be located on the second floor of Bldg. 3525

9 Cost estimate for the design, fabrication, and installation of the March 1995 reference design basic $\mathrm{CH}$-TRU glove box option to be located on the second floor of Bldg. 3525 


\section{LIST OF FIGURES}

$\underline{\text { Figure }}$

$\underline{\text { Page }}$

1 Major work elements of the project to modify the Irradiated Fuel Examination Laboratory (Bldg. 3525) for repackaging CH-TRU drums. . . . . . . . . . . . 2

2 Layout of the April 1994 reference design concept for repackaging CH-TRU drums.. . . . . 5

31985 ORNL glove box facility for characterizing the contents of 55-gal CH-TRU drums.

4 Layout of October 1994 reference design concept for repackaging CH-TRU drums... . . . 13

5 Plan view of November 1994 shielded glove box reference design. $\ldots \ldots \ldots \ldots \ldots 17$

6 November 1994 shielded glove box reference design in Bldg. 3525 basement. . . . . . . . 19

7 Interior view of November 1994 shielded glove box reference design.. . . . . . . . . . 21

8 November 1994 shielded glove box design showing internal equipment arrangement. . . . . 23

9 Schedule for a comprehensive study of Bldg. 3525 to determine the best utilization

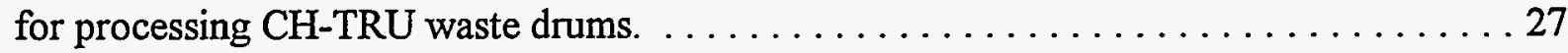

10 Dose rate exposure data (total gamma + neutron) for 2 persons handling CH-TRU

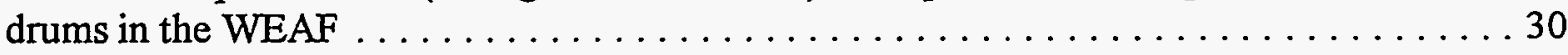

11 CH-TRU drums in the SWIMS database sorted by external surface dose rate from

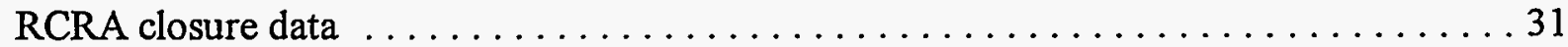

12 CH-TRU drums in the SWIMS inventory database by building (generator) $\ldots \ldots \ldots . \ldots 32$

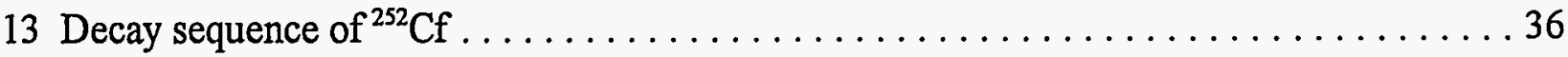

14 Real time radiograph provides excellent information on the content of drums ........43

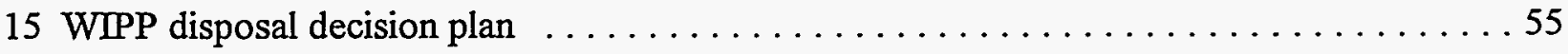

16 National TRU waste characterization program elements. . . . . . . . . . . . 57

17 March 1995 reference design glove box.. . . . . . . . . . . . . . . . . 65 
Figure

18 March $1995 \mathrm{CH}-\mathrm{TRU}$ reference glove box in minimum risk configuration.. . . . . . . 67

19 March 1995 reference design minimum glove box. . . . . . . . . . . . . . . . . 69

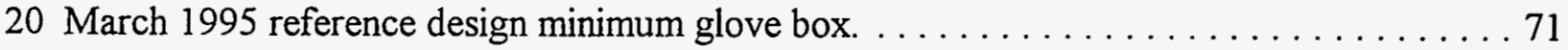

21 March 1995 reference design layout showing facility with optional shielded section

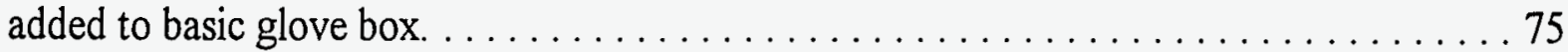

22 March 1995 reference design with optional shielded section added. . . . . . . . . 77

23 March 1995 reference design.. . . . . . . . . . . . . . . . . . . . . . . . . . . . . 79

24 March 1995 reference design.. . . . . . . . . . . . . . . . . . . . . 81

25 Schematic of ventilation system for March 1995 reference design glove box on

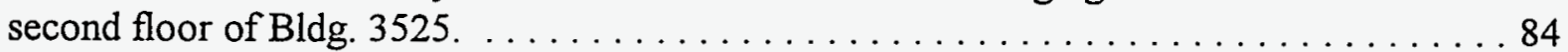

26 Wooden structural frame design for the mock-up facility. . . . . . . . . . . 87

$27 \mathrm{CH}-\mathrm{TRU}$ drum characterization mock-up in Bldg. 3012 . . . . . . . . . . . . . . . 89

$28 \mathrm{CRL}$ drum-in device operating procedures. $\ldots \ldots \ldots \ldots \ldots \ldots \ldots \ldots \ldots \ldots \ldots \ldots \ldots$

$29 \mathrm{CRL}$ drum-in device mounted in mock-up facility glove box. . . . . . . . . . . . 93

$30 \mathrm{CRL}$ drum-out device mounted in mock-up facility $\ldots \ldots \ldots \ldots \ldots \ldots$

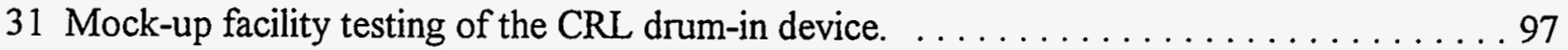

32 Testing of the mock-up facility of the CRL drum-in device. $\ldots \ldots \ldots \ldots \ldots 1$

$33 \mathrm{CRL}$ drum removal operation just prior to cutting the twist-sealed PVC bag. . . . . . 105

34 Drum interior bag after seperation from the glove box just prior to placement of the drum lid. 107

$35 \mathrm{CRL}$ drum-out device operating procedures 109 


\section{LIST OF ACRONYMS}

ALARA As low as reasonably achievable

ANLW Argonne National Laboratory West

APNEA Active and passive neutron examination and assay

ATN Accountability number

$\mathrm{CH} \quad$ Contact handled

CH-TRU Contact-handled transuranic

CRL Central Research Labs

DDP Disposal Decision Plan

DOE Department of Energy

EPA Environmental Protection Agency

HEP Health Equivalent Plutonium

HEPA High Efficiency Particulate Air

HP Health Physics

HVAC Heating Ventilation Air Conditioning

IFEL Irradiated Fuel Examination Laboratory

INEL Idaho National Engineering Laboratory

M\&C Metals and Ceramics Division

NBS National Bureau of Standards

NEPA National Environmental Policy Act

NTPO National Transuranic Program Office

ORNL Oak Ridge National Laboratory

PA Performance assessment

PAC Program Assessments and Certification

PAN Passive-Active Neutron

PBWAC Performance Base Waste Acceptance Criteria

PVC Polyvinyl chloride

QA Quality Assurance

QAPP Quality Assurance Program Plan

RCRA Resource Conservation and Recovery Act

REDC Radiochemical Engineering and Development center

RTR Real time radiography

SWIMS Solid Waste Information Management System

TRU Transuranic

VOC Volatile organic compounds

WAC Waste acceptance criteria

WACCC Waste Acceptance Criteria Certification Committee

WCF Waste Characterization Facility

WEAF Waste Examination and Assay Facitlity

WIPP Waste Isolation Pilot Plant

WMRAD Waste Management and Remedial Action Division

WTWBIR WIPP Transuranic Waste Baseline Inventory Report 



\section{EXECUTIVE SUMMARY}

For the last 25 years, the Oak Ridge National Laboratory (ORNL) has conducted operations which have generated solid, contact-handled transuranic (CH-TRU) waste. At present the CH-TRU waste inventory at ORNL is about 340055 -gal drums retrievably stored in RCRA-permitted, aboveground facilities. Of the 3400 drums, approximately 2600 drums will need to be repackaged. The current U. S. Department of Energy (DOE) strategy for disposal of these drums is to transport them to the Waste Isolation Pilot Plant (WIPP) in New Mexico which only accepts TRU waste that meets a very specific set of criteria documented in the WIPP-WAC (waste acceptance criteria). This report describes activities that were performed from January 1994 to May 1995 associated with the design and preparation of an existing facility for repackaging and certifying some or all of the CH-TRU drums at ORNL to meet the WIPP-WAC. For this study, the Irradiated Fuel Examination Laboratory (IFEL) in Building 3525 was selected as the reference facility for modification. These design activities were terminated in May 1995 as more attractive options for $\mathrm{CH}$-TRU waste repackaging were considered to be available. As a result, this document serves as a final report of those design activities.

A key early activity associated with this design project was the benchmarking of the initial IFEL designs to related design work being performed by Idaho National Engineering Laboratory (INEL) and Argonne National Laboratory West (ANLW). During a two-day visit of these sites in October 1994, much design-related information was found. Of particular note was the fact that INEL had determined that old waste drums were extremely difficult to open. As a result, they performed extensive evaluation of methods to open old carbon steel drums and chose to overcome these potential difficulties by cutting the top of the drums off.

Concurrent with the trip to INEL and ANLW, and throughout this design effort, we conducted detailed studies of the radiological characteristics of the CH-TRU inventory at ORNL. These studies utilized extensive physical and radiological knowledge obtained from the following sources:

1. interviews of various waste generator operators and health physicists,

2. interviews of Waste Examination and Assay Facility (WEAF) personnel and review of accumulated analytical data, 
3. work with waste management personnel, both inside and outside ORNL,

4. examination of existing health physics data and inventory data on the existing CH-TRU drums, and

5. visual analyses of real-time radiography (RTR) surveys of drums.

Much of the analyses and existing archival data obtained by this study was compiled into one electronic data base. On the basis of these studies we concluded early in this activity that the CH-TRU waste at ORNL contains far greater radiological hazards than exist in the CH-TRU waste at other DOE facilities. Consequently, the design of a fail-safe repackaging facility to handle these isotopes on a regular operating basis requires great attention to containment of the waste, adequate radiological shielding, and appropriate on-line detection and continuous monitoring equipment.

During the course of this study four designs were developed and are described in detail in this report. In general each of these concepts is identified by the month that the design reached sufficient maturity that a cursory cost for the approach could be developed. The initial approach, called the "April design," provided minimal radiation protection and utilized the bag and tape approach used in ORNL hot cells for loading the drums into or out of the repackaging facility. This design was replaced by the "October reference design," which utilized commercially available devices utilized by INEL to bag the waste drums into and out of the facility.

The visits to INEL and ANLW and our improved knowledge of the radiological hazards associated with the ORNL inventory caused us to rethink these initial two designs. Subsequent efforts to provided radiation shielding adequate to handle any drum in the ORNL inventory and a capability to cut open drums with stuck lids resulted in the "November reference design". Ultimately none of these three designs were considered optimal from a programmatic perspective.

The fourth design, the "March reference design," incorporated the improved features reflecting all the information gathered during the course of this project. For the March reference design, the location for the facility was located on the second floor of Building 3525 instead of the basement. This change provided a considerable savings in both the design of the glove box and the modifications of the building. In addition, this design provided the ability to process a significant number of drums and could be subsequently expanded to handle more hazardous 
drums in the future without retrofitting. This feature was possible due to the greater floor space and ceiling height available on the second floor in Building 3525. This design was thought by the authors to best meet the programmatic requirements.

In addition to design activities, this study reviewed the requirements and the processes for characterizing CH-TRU waste for shipment to WIPP for disposal. This effort identified and planned for those required characterization actions. These activities lead to the conclusion that recovery and compilation of process knowledge on this waste, as started by this project, is essential to subsequent ORNL TRU waste disposal goals.

Early in this project a non-nuclear mock-up of the October reference design was constructed. This mock-up facility proved to be an invaluable resource in providing the capability to easily and quickly evaluate design concepts, and their ancillary components. The initial drum-in/drum-out activities provided many suggestions for design improvements for this device that were given to the developer of these units.

The results of these design activities have yielded significant progress in identifying future options and solutions for ORNL's task of disposing of its CH-TRU waste. Specifically, we have

- benchmarked ORNL's CH-TRU repackaging approach against INEL and ANLW designs;

- characterized and quantified the risks and hazards associated with the ORNL CH-TRU drum inventory by compiling existing and relevant $\mathrm{CH}$-TRU inventory and radiological data into one applicable PC data base;

- developed two CH-TRU repackaging designs approaches to a level of maturity to initiate detailed design and procurement actions;

- assessed WIPP-WAC requirements and plans in order to plan ORNL's characterization, certification, and repackaging activities to support the WIPP-WAC Disposal Decision Plan; and

- significantly advanced the development of the critical bag-in/bag-out devices required for cost effective processing of $\mathrm{CH}-\mathrm{TRU}$ waste. 


\section{INTRODUCTION}

During the last 25 years, the Oak Ridge National Laboratory (ORNL) has conducted operations that have generated solid, contact-handled transuranic (CH-TRU) waste materials. In the CH-TRU waste inventory at ORNL, about 340055 -gal drums are retrievably stored in RCRA-permitted, aboveground facilities. This waste was generated at 41 different buildings and continues to grow at a rate of about 40 to 60 new drums each year.

The current U. S. Department of Energy (DOE) strategy for disposal of these drums is to transport them to the Waste Isolation Pilot Plant (WIPP) in New Mexico. The WIPP facility is being managed to accept only TRU waste that meets a very specific set of criteria called WIPP-WAC (waste acceptance criteria). This report describes activities that were performed to design and operate a facility for repackaging and certifying some or all of ORNL's CH-TRU drums to WIPP-WAC. The objectives for this facility are to repackage the largest number of $\mathrm{CH}$-TRU drums at the lowest possible life cycle cost. Central to the objective of reducing ORNL's capital costs, an existing site - the Irradiated Fuel Examination Laboratory (IFEL) in Building 3525 - was selected for modification. This report identifies IFEL building modifications, new equipment needs, and cost and schedule estimates for these activities and items.

The precursor to this project was an initial proposal (April 1994) in which a conceptual design for this facility was provided. In July 1994, the initial concept design proposal was accepted by the Waste Management and Remedial Action Division (WMRAD), and detailed design efforts for the equipment and its installation in IFEL began. ${ }^{1}$

During the course of these detailed design efforts (July, August, and September of 1994), new information was gained which brought about reevaluation and upgrading of many of the initial proposal concepts. The evolution of these efforts is shown in Fig. 1. This figure lists

"Research sponsored by the U.S. Department of Office of Environmental Waste, U.S.Department of Enegy under contract DE-AC05-84OR21400 with Lockheed Matrin Energy Systems. 


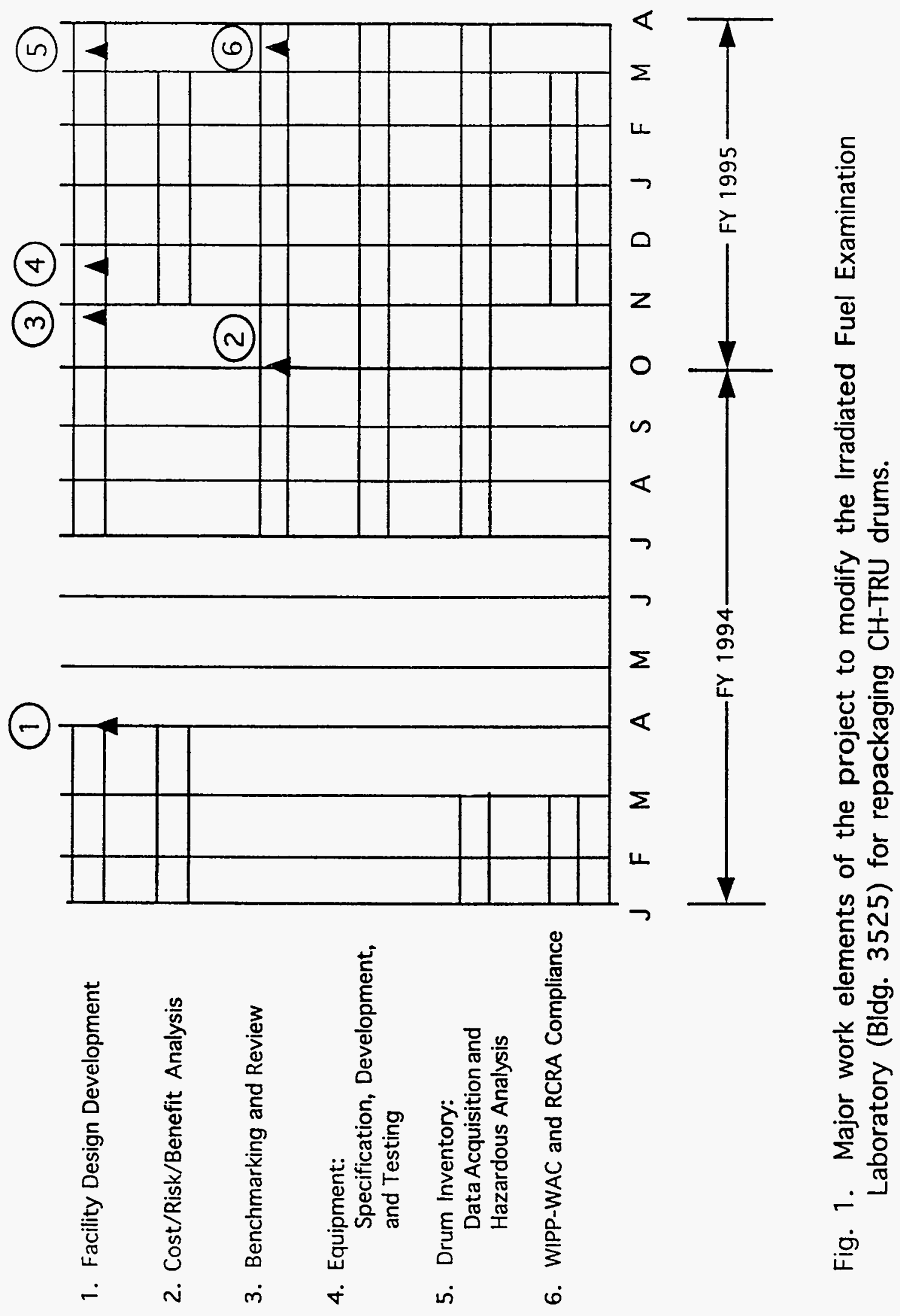


the major work elements associated with the project and shows various milestones, self imposed by the design team working on the project, which were completed in order to arrive at a viable facility design.

The remainder of this report will describe, in detail, important aspects of the work elements in Fig. 1. The presentation of this material will first describe, in Section 2, the major features of three specific facility designs, referred to as the April Design, October Reference Design, and November Reference Design, milestones 1, 3, and 4 in Fig. 1. Ultimately, none of these three designs were considered optimal from a programmatic perspective. Section 3 will describe an analysis of the contents of $\mathrm{CH}$-TRU drum materials, oriented towards packaging facility design. Section 4 describes the requirements, criterion, and strategy for repackaging ORNL's CH-TRU, again oriented towards the design of this facility. Section 5 will describe the facility referred to as the March Reference Design, milestone 5 in Fig. 1. This design incorporates improved features reflective of all the information gathered during the course of this project and was thought by the authors to best meet the programmatic requirements. Finally, Section 6 will describe details of a mock-up facility design and operation which were developed to support all aspects of this project's implementation.

\section{BACKGROUND}

Guided by the April 1994 conceptual design described in the initial proposal, various activities were started in July 1994: (1) glove box design, (2) equipment specification formulation, (3) Building 3525 basement decontamination, (4) mock-up facility design and construction, (5) drum content analysis, and (6) drum selection criteria formulation. ${ }^{1}$

\subsection{GLOVE BOX REFERENCE DESIGN}

This effort began with detailed engineering for glove box procurement. An experienced glove box specialist was added to the CH-TRU design team. Glove box layouts were prepared

for the Building 3525 basement in sufficient detail to enable glove box and equipment vendors to provide preliminary schedule and cost information from them. Fig. 2 is typical of the many 



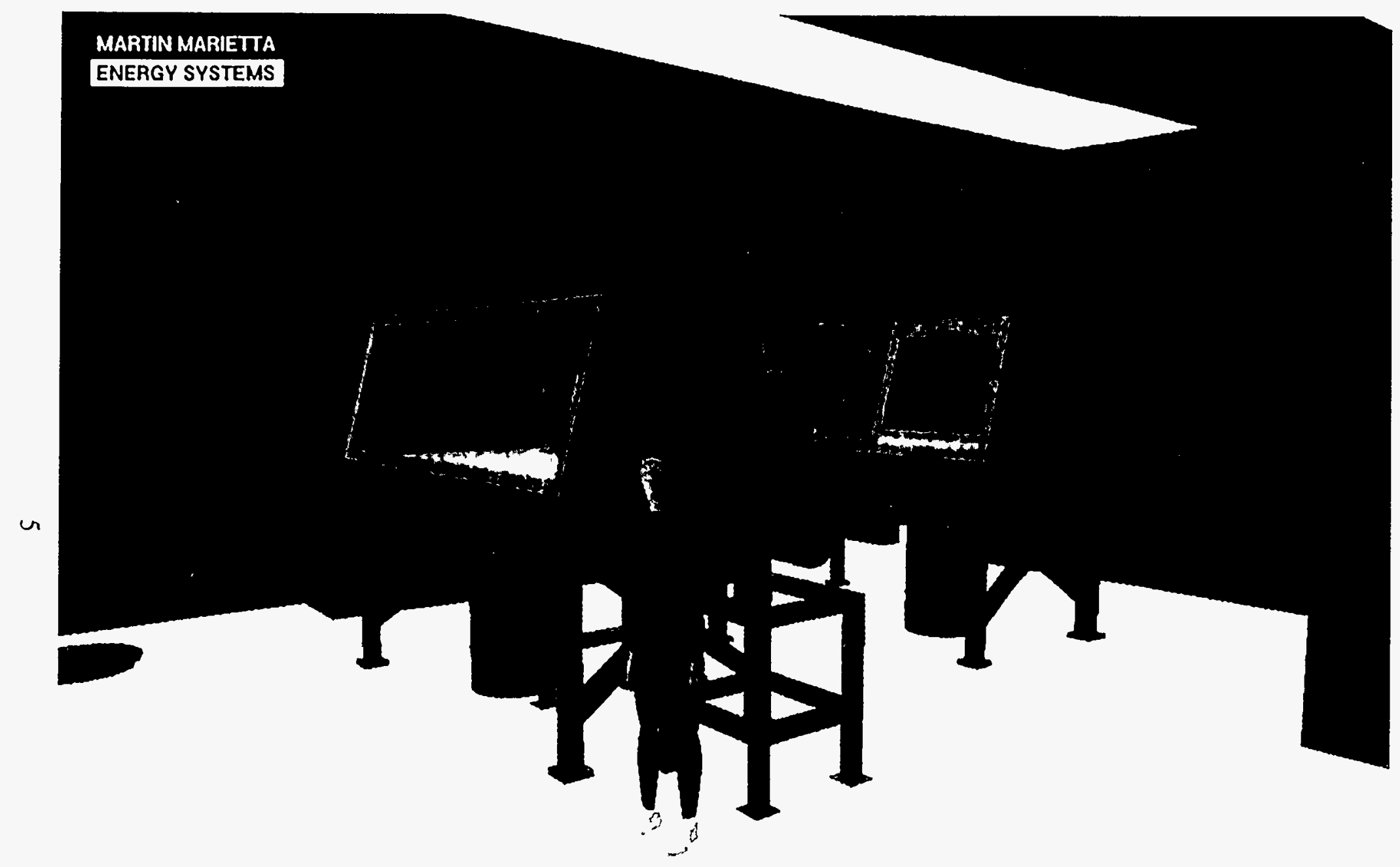

Fig. 2. Layout of the April 94 reference design concept for repacking $\mathrm{CH}-\mathrm{TRU}$ drums. Glove box facility is shown in the basement of Bldg. 3525. 

facility layout illustrations produced. In this regard, a complete set of drawings was obtained for IFEL and were updated to show the current configuration of the basement, which included extensive utility piping, HVAC ducting, and additional mechanical and electrical equipment. Some of these items were found to interfere with preferred placement of the glove box and its ancillaries. Interviews with Building 3525 operations staff led to the conclusion that much of this equipment could be removed.

The reference glove box system shown in Fig. 2 had several major attributes: (1) provided about $120 \mathrm{ft}^{2}$ of internal working surface, (2) provided the capability to interface a low-speed 40-hp shredder for volume reduction and waste debris homogenization, (3) could be fabricated from conventional glove box components if appropriately modified to interface with a shredder and special 55-gal drum interface flanges, (4) provided ample floor space for drum egress and storage in the Building 3525 basement, and (5) the April 1994 reference design (Fig. 2) employed features which allowed a 55 -gal drum to be bagged-in/bagged-out by procedures previously approved for transuranic glove box operation in a circa 1985 ORNL facility (Fig. 3.)

\subsection{BENCHMARKING THE REFERENCE DESIGN}

During the refinement of the April 1994 reference design, several team members attended the National Glove Box Conference to discuss fabrication and procurement issues. At this conference, contacts were made with personnel from Idaho National Engineering Laboratory (INEL) and Argonne National Laboratory West (ANLW).

INEL had been working for more than four years on the design of the Waste Characterization Facility (WCF) to repackage CH-TRU waste stored in drums. Arrangements were made with INEL's management to review and compare our similar projects. ORNL's objective was to investigate their design experience and development programs to determine if we could take advantage of this experience, by benchmarking our reference design concept.

During two days of meetings, much design-related information was found to be of value to ORNL's CH-TRU project. Of particular note were INEL's methods for opening drums in their facility. They had done extensive testing of methods to open old carbon steel drums and 


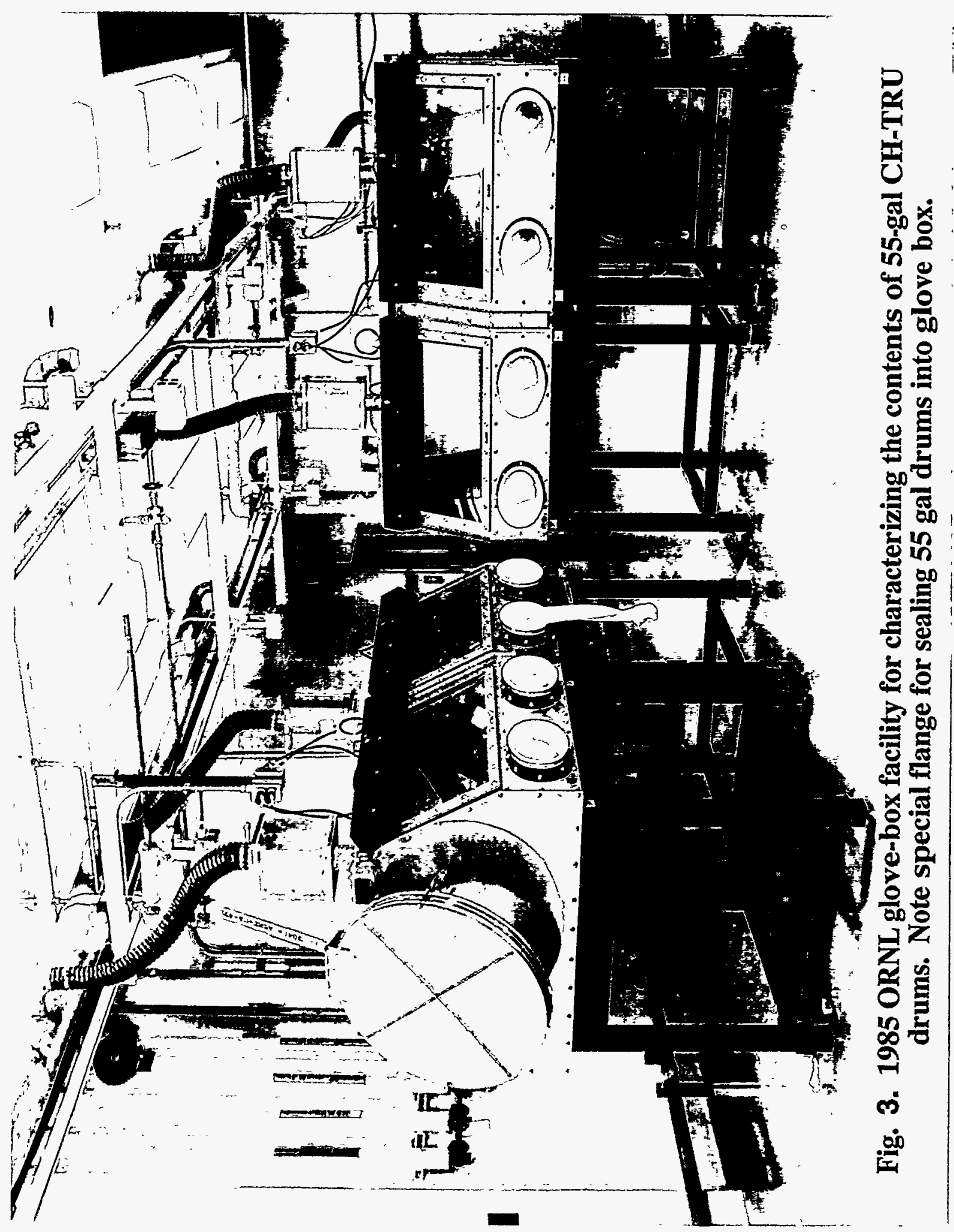


found that old drums can be extremely difficult to open for several reasons. Their design approach to overcome these potential difficulties was to cut the drum tops off and then repackage the old drum after cutting it into small sheet metal pieces.

Concurrent with the trip to INEL, our analyst was conducting a more detailed study of the radiological characteristics of ORNL's CH-TRU drum-stored wastes. This study caused us to rethink the whole reference design concept and take a much more detailed look at shielding and dose monitoring. In addition, the visit to INEL and ANLW caused us to consider the consequences of processing drums that did not open easily.

\subsection{REFORMULATION OF THE APRIL 1994 REFERENCE DESIGN}

The visits to INEL and ANLW motivated efforts to improve our reference design. The improvements focused our efforts to find solutions to problems of difficulty in opening drums and removing their contents. Apparently, drum corrosion, radiation damage, and/or aging of elastomeric drum contents (drum seals, plastic bags, and bottles) were the major contributors to these problems.

In our April 1994 reference concept, drums were assumed to open easily and their contents assumed to slide out easily. If this were not the case, the fragility of the drum to glove box seal interface becomes a major impediment to safe operation. A partial design solution for these anticipated problems of drum opening and glove box sealing was conceptualized and is shown in the October reference design (Fig. 4). In Fig. 4, a new technique for sealing drums into a glove box is shown. The new design is engineered to be rugged by using $\mathrm{O}$-ring-sealed flanges

that mate to 55-gal drum features. This new drum-in/drum-out approach was being developed by Central Research Labs (CRL) of Redwing, Minnesota with which we negotiated the loan of actual prototype system for testing in the mock-up facility, which at the time was under construction.

Other improved features of the October 1994 reference design were that the drums would be unloaded in a vertical orientation. At this time, some of our preliminary radiological information indicated that probable local concentrations of "hot" material within a drum could lead to excessive operator exposure. In order to eliminate this possibility, the October 1994 



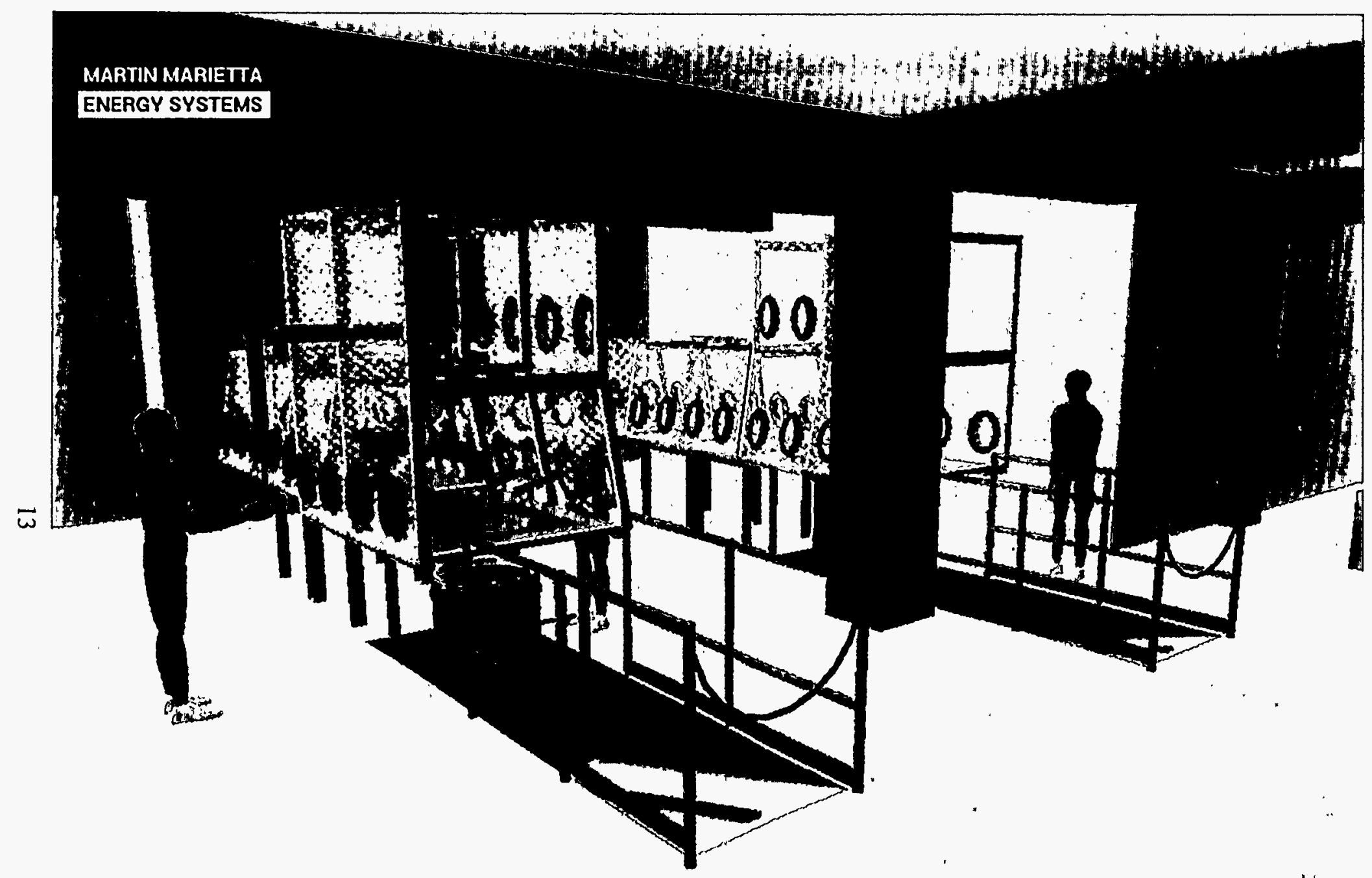

Fig. 4. Layout of October 94 reference design concept for repacking CH-TRU drums. Glove-box facility is shown in the basement of Bldg. 3525. 

reference design employed a small master slave manipulator to first remove drum contents. Procedures and equipment would be used to survey items as they were removed from the drum to ensure they could be safely handled in a glove-box system. In addition, the vertical unloading provided the possibility of processing drums containing liquids and sludges without causing internal glove-box spills.

Even though the CRL approach would better handle situations in which the drum does not open or the contents are difficult to remove, there were still concerns that the October 1994 reference design would still be too fragile if subjected to the mechanical forces that would be required should the drum tops have to be pried or cut open. In addition, prying and cutting would create sharp metal drum edges and chards that would make drum removal from the glove box and internal handling a risky task for operators using gloves and manual tools.

An integrated design solution that addressed all the opening, sealing, bag-out synergism is shown in Figs. 5 through 8. In this November 1994 design, the incoming drums would be sealed into the glove box floor using the CRL systems, which if viewed on the glove box interior, would appear as shown in Fig. 7. Once the drum was sealed into the glove box, it would be lifted with the overhead monorail winch and moved to a fixture that would rigidly lock the drum into a position adjacent to a hydraulic manipulator. The currently available technology for manipulators of this type would allow removal of the drum top, even if cutting were necessary. In addition, the capability of the manipulator would also allow complete dissection of the drum into pieces of sheet metal small enough to be further processed by a relatively small internal shredder. This scenario, which was originally motivated only by fail-safe drum opening concerns, led to a credible technique to process the old incoming drums into the new outgoing drums containing the waste.

Once a design commitment was made to use a hydraulic manipulator, simple considerations of making use of this expanded capability led to other, straightforward improvements. For instance, one of the severely limiting characteristics of the drum inventory with respect to glove box processing was that there was a significant number of the drums in the inventory containing isotopes that are vigorous neutron, gamma, and high-energy beta emitters. In our April 1994 and October 1994 reference designs, the strategy for obtaining as low are 



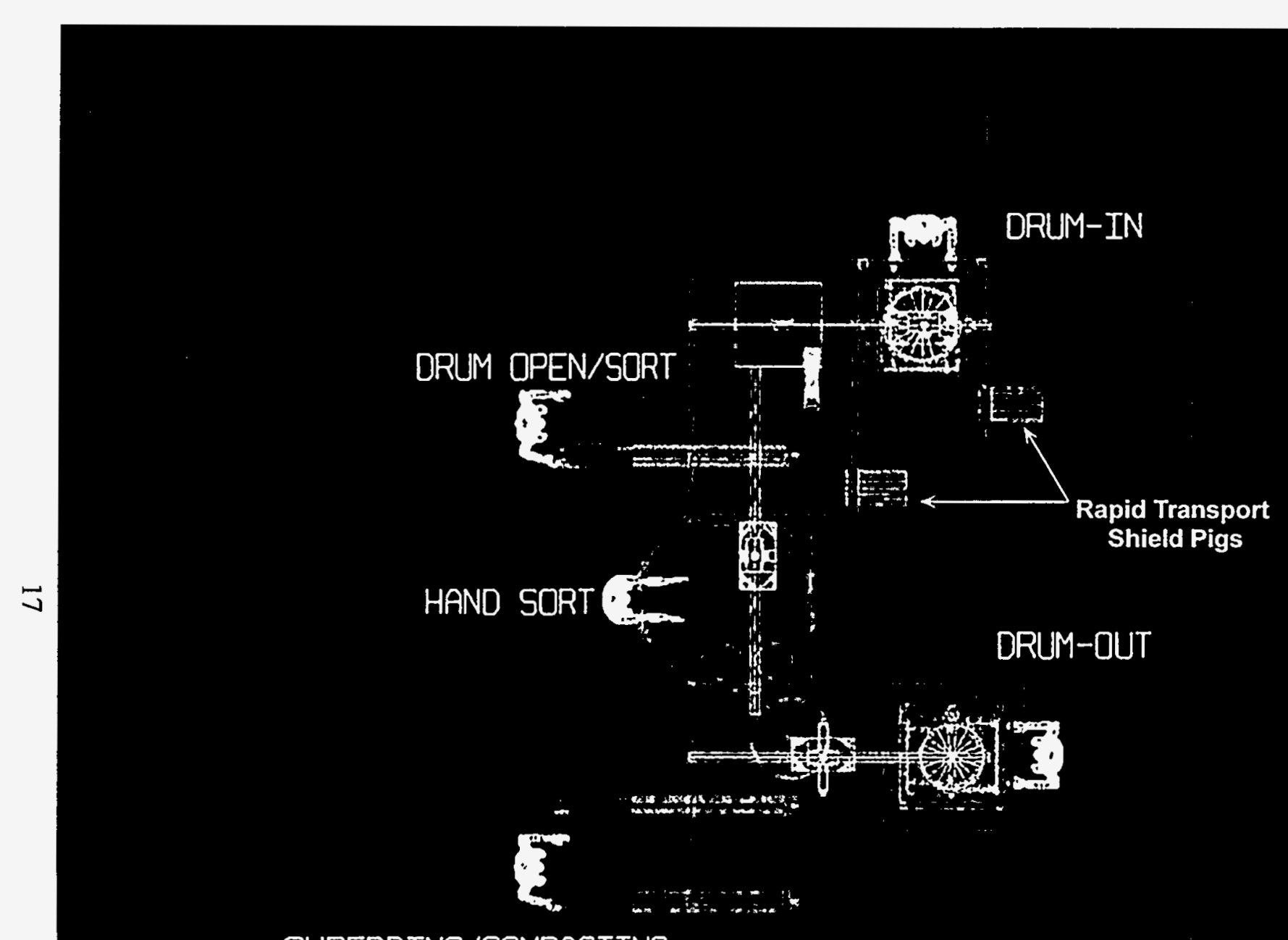

SHREDOING/COMPACTING

Fig. 5. Plan view of November 94 shielded glove box reference design. Configuration shown is sized for the basement of Bldg. 3525 . 



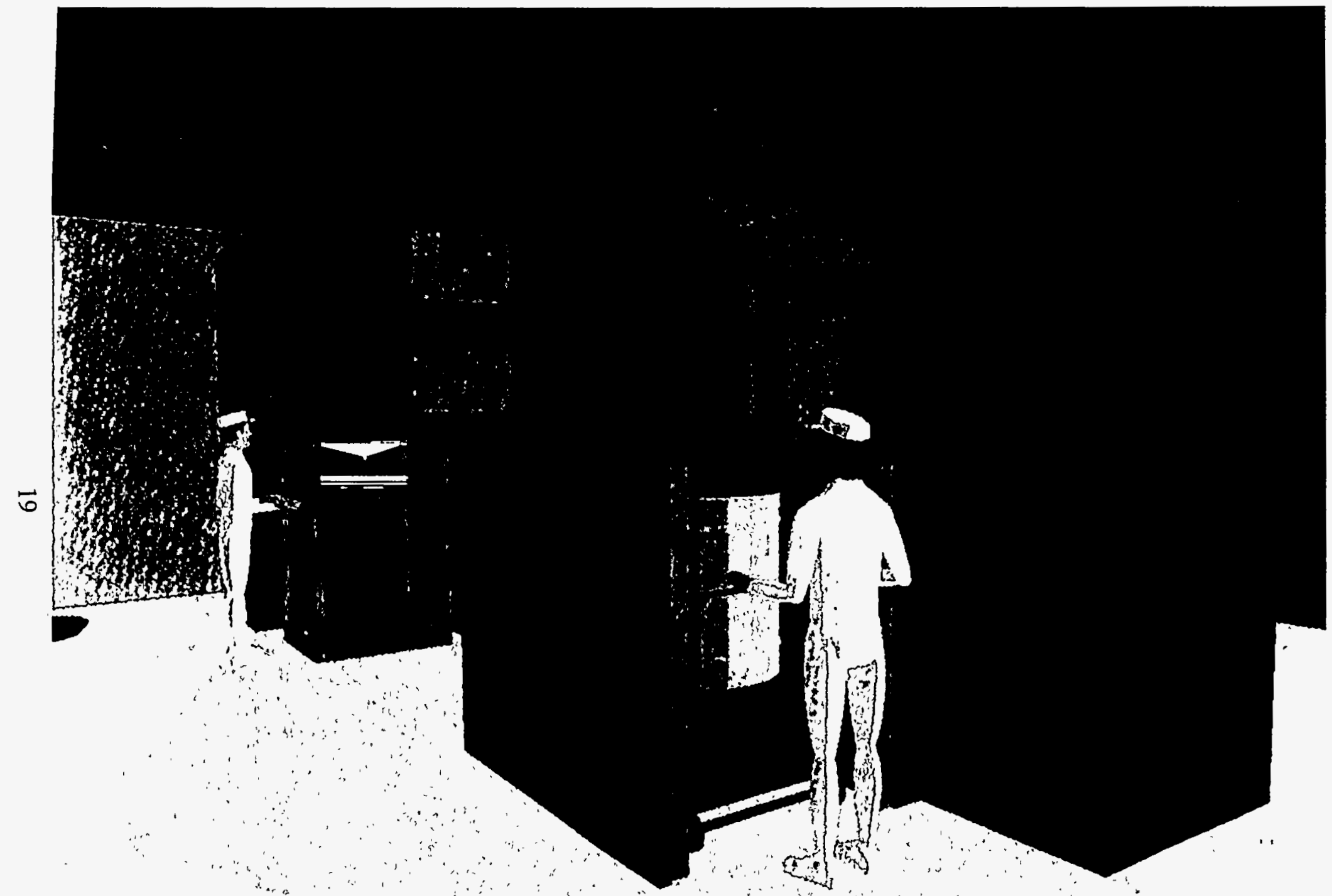

Fig. 6: November 94 shielded glove-box reference design in Bldg. 3525 basement. Central Research Laboratory, drum-in/drum-out devices are shown. 



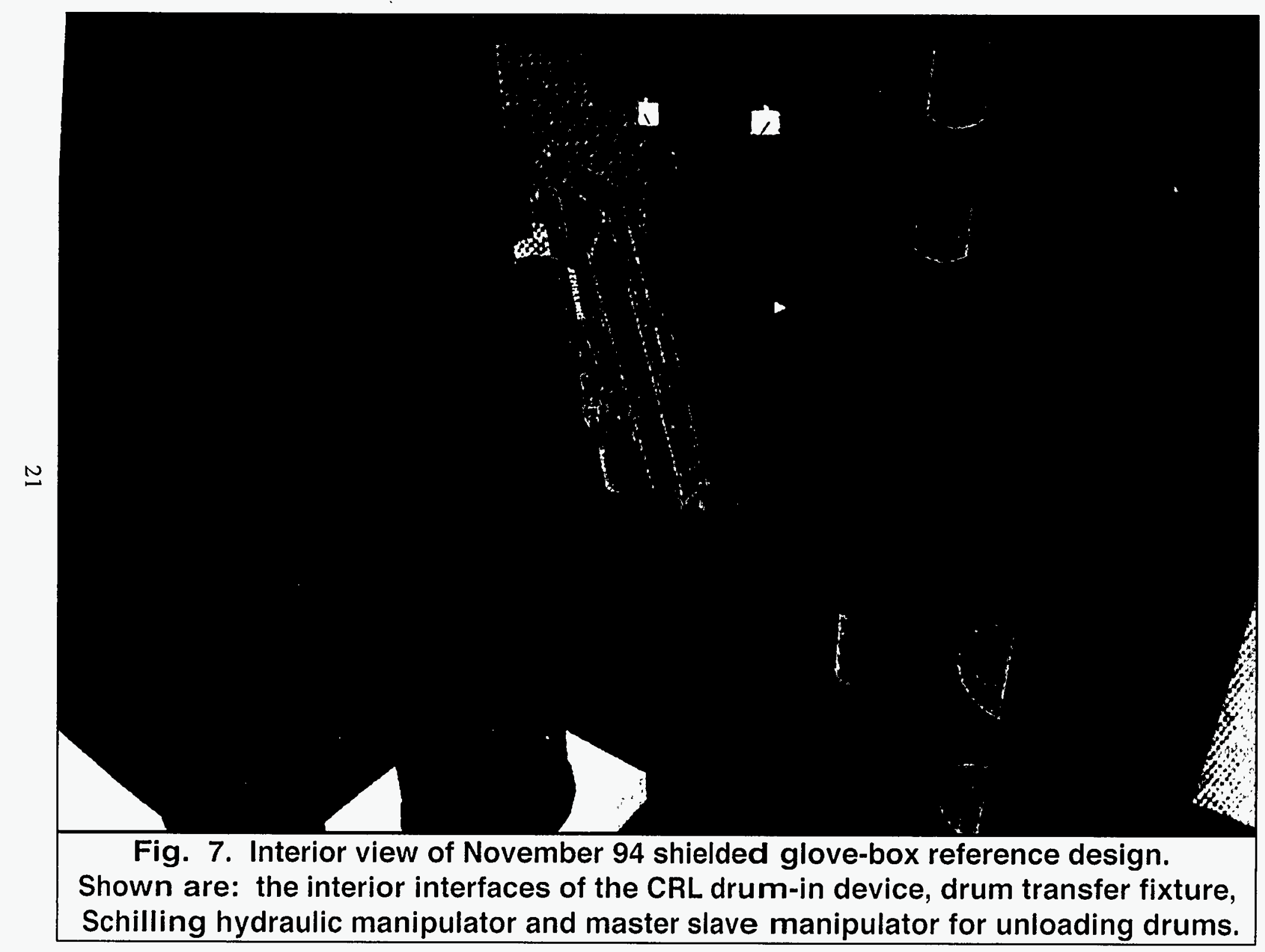








<smiles></smiles> 
reasonably achievable (ALARA) worker exposure goals was to screen the incoming drums using the available data bases; this strategy was based on drum exterior measurements to ensure glove box operator protection. This drum selection criterion may be inadequate because limited information is available concerning either the distribution or concentration of isotopes within a given drum. Given these facts, several strategies were further developed for glove-box-like processing.

If the design were to incorporate an optimized shielding design for different sections of the glove box dependent on what operations are performed and adopt an internal configuration as shown in Fig. 8, probably most of the 2600 drums could be repackaged. Such a design would use the manipulators shown to unload the drums in the first shielded section. Items that were radiologically too hot to handle in a glove box environment could be bagged out into a shielded pig and transported to a hot cell. Other items found to be radiologically safe but requiring manual sorting, unpackaging, or visual examination could be transferred to the glove box section for these operations. Alternatively, options would be provided for transfer directly from the shielded cave to the bag-out section. For instance, items such as sharp sheet metal chards or broken glass would probably fall in this category.

Other inherent capabilities of the improved November 1994 reference design would be the possibility of processing liquid drum contents. Because the drums would now be introduced into the glove box in a vertical position, procedures for processing liquids without uncontrolled spills appeared credible. The treatment of liquids for WIPP acceptance ultimately amounts to chemical processing that converts liquid wastes to solid hydrates or other solid polymers. The design shown in Fig. 8 conceptually provides a multitude of mechanical options and capability for processing liquids safely.

The improved November 1994 design resulted in a highly specialized glove box system that was far beyond the scope of our original proposal. The development of this design was the result of initial attempts to progress from our early conceptual ideas to arrive at a detailed engineered system. During these efforts, new information was obtained from other, more mature CH-TRU programs at INEL, ANLW, and Hanford. In addition, a more detailed analysis of drum 
contents and the requisite neutron detection and shielding requirements considerably altered our earlier conceptual thinking.

Cost and schedule for the highly specialized design were estimated at about $\$ 8.5 \mathrm{M}$ and 36 months, respectively. Discussions with WMRAD staff on pursuing further design activities on this approach were discouraged in the near term because of their budget and schedule constraints.

\subsection{COST/BENEFIT STUDY PROPOSAL}

At the completion of the November 1994 reference design, three distinctly different engineered systems were known to be candidates to process CH-TRU drums in Building 3525 . Each of these alternatives had been studied to different levels and, as a result, were not clearly discernible as distinct engineering alternatives (Fig. 9).

WMRAD was presented with a new proposal to conduct an in-depth study of the alternatives shown in Fig. 9. This study, which began in December 1994, would be phased such that each alternative would be developed and receive both internal and external review. Completion of the study would provide cost, schedule, and risk assessment so that DOE and WMRAD could effectively plan CH-TRU waste remediation against budget constraints and requirements.

During the next several months, the first alternative for a low-risk prototype glove box approach was reexamined and the improved concepts and increased knowledge just described were incorporated. These major changes and improvements to the original reference design were made with only minor changes in the original budget and schedule.

The most obvious improvements to the new design were (1) that the second floor of Building 3525 would be much more suitable as a location and (2) the design would incorporate the CRL bag-in/bag-out devices, vastly improving safety in drum handling. In addition, the CRL devices provide the opportunity to process a larger cross section of the drum inventory, possibly including liquids, sludges, heavy items, etc.

Section 5 of this report will focus on the details of the improved reference design (March 1995). It has been estimated that the cost would be about $\$ 3 \mathrm{M}$ and that it would require 27 months to prepare for operation. The expected processible part of the CH-TRU drum 


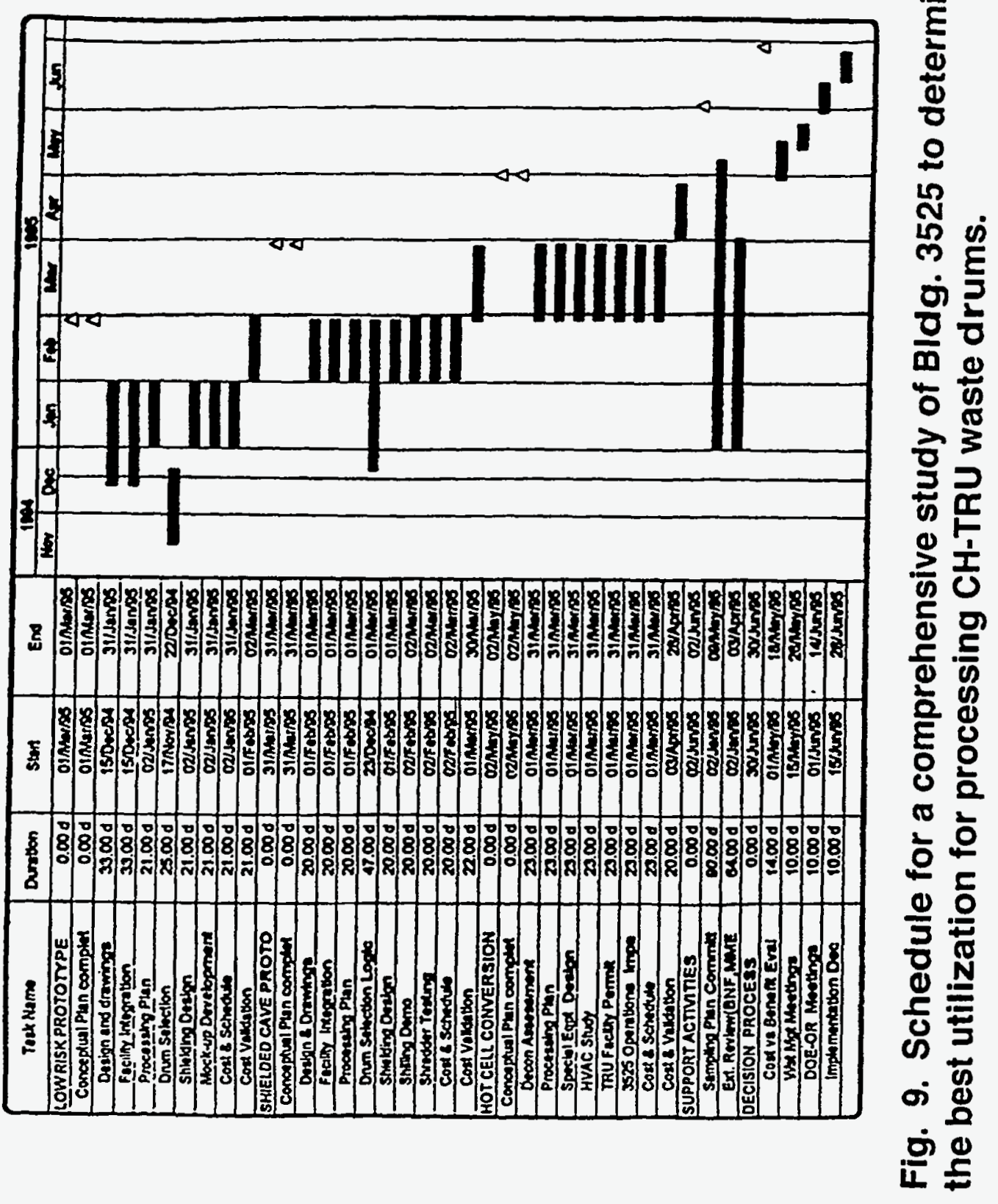


inventory in this facility should be about 1000 to 1200 drums: the design would also allow the optional addition of a neutron and gamma-shielded section for processing the other 1400 to 1600 drums. The decision to add this section would be based on experience gained in the initial operation of the glove box section, availability of funding, and probably the confidence at that time that it was the best option.

\section{CH-TRU DRUM CONTENT DATA}

Critical to the processes required to design, construct, and operate an efficient and safe facility to repackage legacy CH-TRU waste at ORNL is the requirement that an accurate description of the waste be available. It will be shown that the diverse range of physical, chemical, and radiological materials contained in the ORNL inventory not only affects how the facility is designed but also defines the strategy for selecting the number of drums and the order in which they will be processed. The questions that we have attempted to answer are

1. What materials are contained in the drums?

2. What is the likely physical condition of the materials within the drums?

3. What do we have to do with what we think is there to prepare this material for WIPP?

At the start of this study, we believed that a substantial number of the CH-TRU drums could easily be selected for processing and repackaging based on information in existing data sets. Further study, however, indicated serious deficiencies concerning the availability, credibility, and usefulness of existing data in the specific context of designing and operating a facility to process this material. Fortunately, this situation was recognized early in the project and significant improvements have been made toward locating and organizing this data into useful design and operating information.

Although the remainder of this section will elaborate on drum content information as it applies to the design of a safe and cost-effective facility, much work remains to be done to better characterize the wastes for safely operating such a facility. Besides the facility design and operation requirements, there are other very pragmatic reasons for having good generator data. For example, one approach to providing certified waste drums to WIPP might be formulated 
whereby only a small fraction of drums in the CH-TRU inventory would have to be opened. This strategy would use the repackaging facility as described in this document only as a tool for verifying existing generator data. The potentially enormous operational cost savings of such a strategy should justify top priority being given to drum content evaluation from existing generator records. The remainder of this section will describe how effective such efforts have been in providing facility-specific design information for this project.

\subsection{DATA ACQUISITION}

During the course of this project, extensive physical and radiological knowledge from a variety of sources has been accumulated and organized. The sources were

1. interviews of various waste generator operators and health physicists,

2. interviews of Waste Examination and Assay Facility (WEAF) personnel and review of accumulated analytical data,

3. work with waste management personnel, both inside and outside ORNL, and

4. examination of existing data for the purpose of compiling it into a single data base.

In addition, literature searches were made for reports of operational experience with TRU isotopes. Extensive visual analyses of real-time radiography (RTR) surveys were also performed, which provided physical content data for many drums. Much of the analyses and existing archival data has been compiled into one data base which although vastly improved, is still not complete at this time. A broad range of information was accumulated, such as exposure dose rate data over several years for workers handling CH-TRU drums in WEAF (Fig. 10), classification of the $\mathrm{CH}-$ TRU drum inventory in terms of incremental external surface dose rate (Fig. 11), classification of a substantial portion of the drum inventory by generator (Fig. 12), tabulation of radioactivity of TRU isotopes (Table 1), tabulation of radiotoxicity of TRU isotopes per existing health physics (HP) guidelines (Table 2), compilation of radioactivity emission characteristics of TRU isotopes and calculated emission physics relative to dose rates (Table 3), charting of isotopic decay sequences (Fig. 13), evaluation of drum-specific neutron physics (Table 4), determination of neutron exposure dose rate limits to meet ALARA goals (Table 5), evaluation of quantities of isotopes in selected drums within a specific external surface dose rate range (Table 6), and 


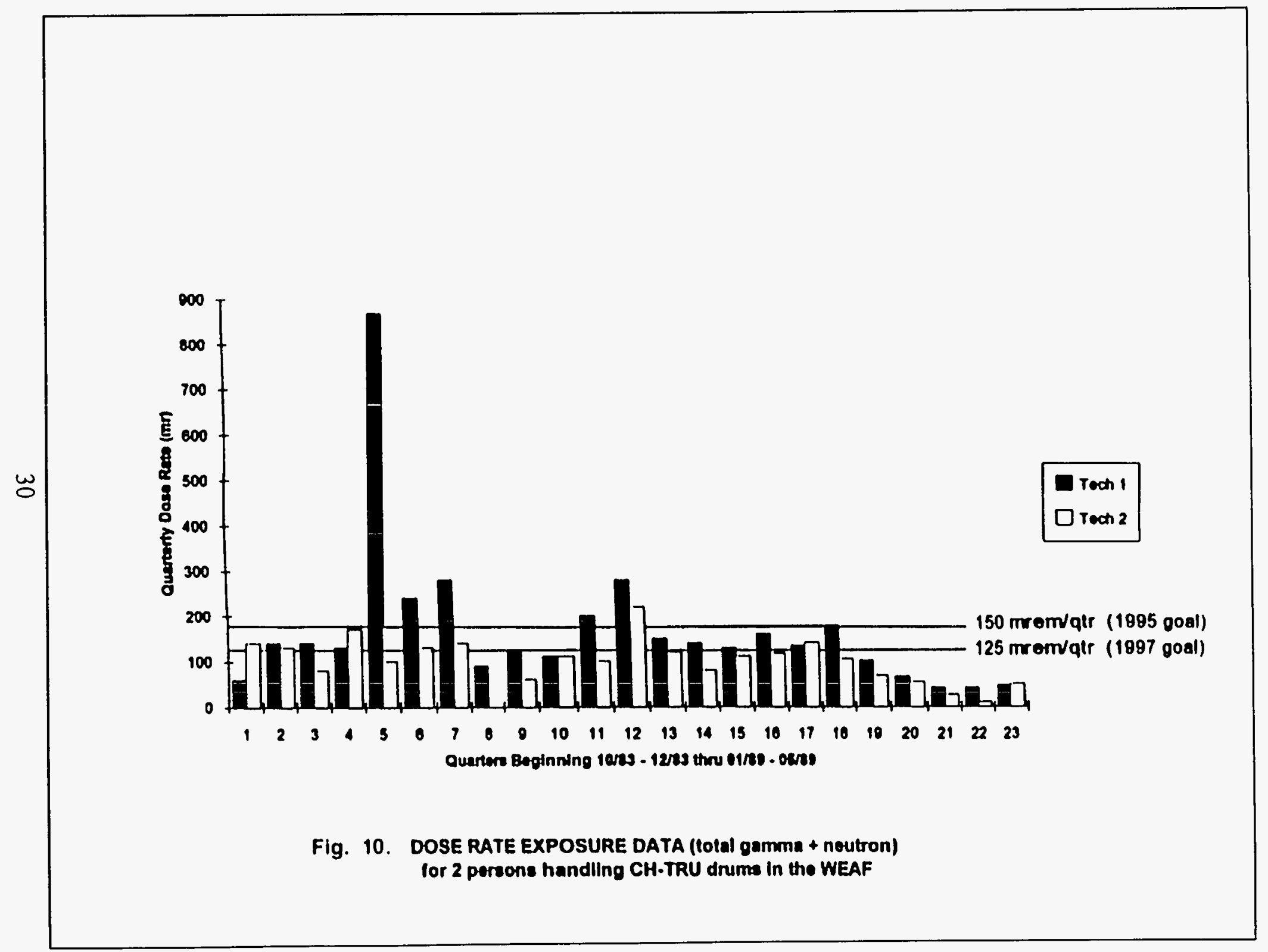



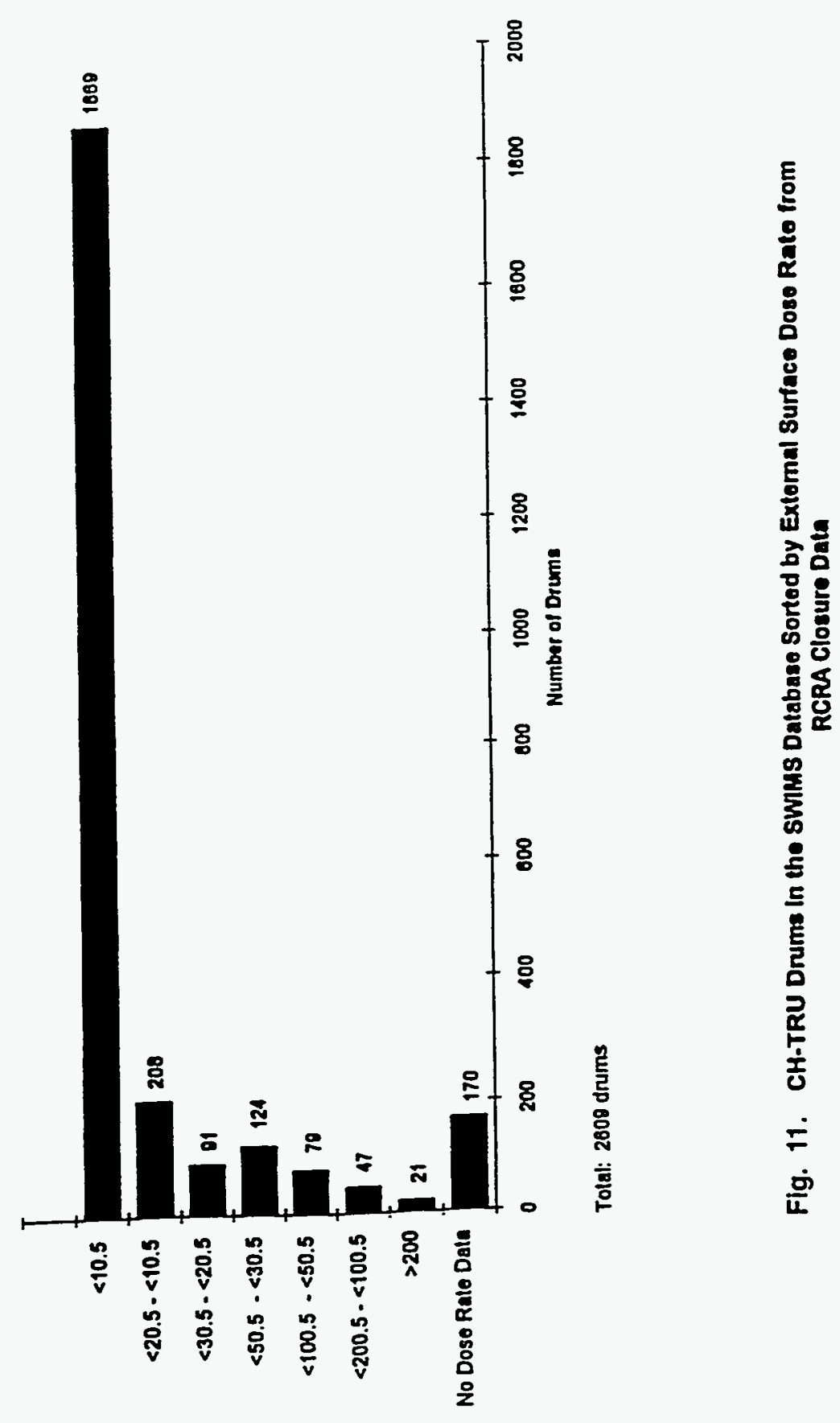





Table 1. Radioactivity of TRU Isotopes

\section{Isotope}

Americum-241

Americum-243

Berkelium-249

Californium-249

Californium-250

Californium-252

Curium-242

Curium-244

Curium-248

Plutonium-238

Plutonium-239

Plutonium-240

Plutonium-241

Plutonium-242

Promethium-147

Neptunium-237

Radium-226

Uranium-233

Uranium-235

Uranium-238
Specific

(Ci/gram)
3.43

0.20

1,639

4.10

109.3

536.3

$3,311.4$

80.9

$4.2 \times 10^{-3}$

17.12

$6.2 \times 10^{-2}$

0.23

103.0

$4 \times 10^{-2}$

927.0

$7.1 \times 10^{-4}$

0.99

$9.6 \times 10^{-3}$

$1.9 \times 10^{-6}$

small

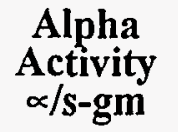

\section{Beta \\ Activity $\beta /$ s-gm}

$1.3 \times 10^{11}$

$7.4 \times 10^{9}$

$8.8 \times 10^{8}$

$1.510^{11}$

$4.1 \times 10^{12}$

$1.9 \times 10^{13}$

$1.3 \times 10^{14}$

$3.0 \times 10^{12}$

$1.4 \times 10^{8}$

$6.3 \times 10^{11}$

$2.3 \times 10^{9}$

$8.4 \times 10^{9}$

$9.2 \times 10^{7}$

$1.5 \times 10^{8}$

0

$2.6 \times 10^{7}$

$3.7 \times 10^{10}$

$3.6 \times 10^{8}$

$7.0 \times 10^{4}$

small
Gamma
Activity
$\lambda / s-g m$

Neutron

Activity

n/s-gm

\subsection{1}

5.35

$1.1 \times 10^{5}$

2,970

$1.2 \times 10^{11}$

$2.3 \quad 10^{12}$

Approx.

equal to

alpha

activity

or

in

terms

of

number

gammas

per

second.

$3.8 \times 10^{12}$

Usually

in

range.

$2.5 \times 10^{7}$

$1.4 \times 10^{7}$

$4.7 \times 10^{7}$

3,042

0.09

0

0

2,556

$3.3 \times 10^{13}$

0

0

0

0.0011

0

0 
Table 2. Radioactivity guidelines from the ORNL health physics procedure

Isotope

Americum-241

Americum-243

Berkelium-249

Californium-249

Californium-250

Californium-252

Curium-242

Curium-244

Curium-248

Plutonium-238

Plutonium-239

Plutonium-240

Plutonium-241

Plutonium-242

Promethium-147

Radium-226

Neptunium-237

Uranium-233

Uranium-235

Uranium-238
Hazard Equivalent

Plutonium (HEP) Curies

$1.12 \times 10^{-3}$

$1.93 \times 10^{-2}$

$1.73 \times 10^{-1}$

$9.39 \times 10^{-4}$

$9.62 \times 10^{-4}$

$1.92 \times 10^{-3}$

$1.92 \times 10^{-2}$

$7.70 \times 10^{-4}$

not listed

$5.77 \times 10^{-4}$

$6.02 \times 10^{-2}$

$1.70 \times 10^{-2}$

$1.92 \times 10^{-2}$

$9.78 \times 10^{-1}$

$1.15 \times 10^{-1}$

$5.38 \times 10^{-1}$

5.46

3.99

$1.78 \times 10^{4}$

$1.15 \times 10^{5}$
Hazard Equivalent

Plutonium (HEP) grams

$3.26 \times 10^{-4}$

$9.67 \times 10^{-2}$

$1.06 \times 10^{-4}$

$2.29 \times 10^{-4}$

$8.80 \times 10^{-6}$

$3.58 \times 10^{-6}$

$5.82 \times 10^{-6}$

$9.51 \times 10^{-6}$

$3.37 \times 10^{-5}$

1.00

$7.47 \times 10^{-2}$

$1.87 \times 10^{-4}$

$2.49 \times 10^{2}$

$1.24 \times 10^{-2}$

$5.90 \times 10^{-1}$

$7.73 \times 10^{3}$

$4.14 \times 10^{2}$

$8.22 \times 10^{9}$

$3.40 \times 10^{11}$ 
Table 3. Dose calculation data for transuranic isotopes

\begin{tabular}{|c|c|c|c|c|c|c|c|c|}
\hline Isotope & $\begin{array}{l}\text { Specific } \\
\text { Activity } \\
\text { (CV/gmi) }\end{array}$ & $\begin{array}{l}\text { Neutron } \\
\text { activity } \\
\text { per } \mu \text { gm } \\
\text { from SF } \\
\left({ }^{\circ} \text { nsec) }\right.\end{array}$ & $\begin{array}{c}{ }^{\circ} \text { n/sec } @ \\
1 \text { meter } \\
\text { per } \mu g m \text { (m) } \\
\text { (mreni/h) }\end{array}$ & 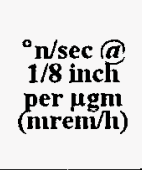 & $\begin{array}{c}\text { Ganuma } \\
\text { activity } \\
\text { per } \mu \text { gm } \\
\text { (cps) }\end{array}$ & $\begin{array}{l}\text { Ganuma } \\
\text { energy, } \\
\text { avg/dis } \\
(\mathrm{KeV})\end{array}$ & $\begin{array}{c}\text { Gamma dose } \\
\underset{\text { meter }}{1 \text { per } \mu \mathrm{gm}} \\
\text { (mren/h) }\end{array}$ & $\begin{array}{c}\text { Gamuma dose } \\
\text { a. 1/8 inch } \\
\text { per kgm } \\
\text { (mr/h) }\end{array}$ \\
\hline${ }^{241} \mathrm{Am}$ & 3.43 & $\begin{array}{c}1.6 \times 10^{-6} \\
\alpha=1.3 \times 10^{5}\end{array}$ & $1.5 \times 10^{-12}$ & $1.5 \times 10^{-7}$ & $1.29 \times 10^{5}$ & 28.7 & $1.3 \times 10^{-3}$ & 129.0 \\
\hline${ }^{249} \mathrm{Cf}$ & 4.1 & $\alpha=\frac{0.003}{\alpha .5 \times 10^{5}}$ & $2.9 \times 10^{9}$ & $3.0 \times 10^{-4}$ & $1.52 \times 10^{5}$ & 326 & $1.5 \times 10^{3}$ & 148.8 \\
\hline${ }^{252} \mathrm{Cf}$ & 536.3 & $\begin{array}{c}2.31 \times 10^{6} \\
\alpha=1.9 \times 10^{7}\end{array}$ & 2.21 & $2.2 \times 10^{5}$ & $1.92 \times 10^{7}$ & 1.14 & 0.19 & $1.9 \times 10^{4}$ \\
\hline${ }^{24} \mathrm{Cm}$ & 80.9 & $\begin{array}{c}13.8 \\
\alpha=3 \times 10^{6}\end{array}$ & $1.3 \times 10^{-5}$ & 1.29 & $3.0 \times 10^{6}$ & 1.6 & 0.03 & $3.0 \times 10^{3}$ \\
\hline${ }^{248} \mathrm{Cm}$ & 0.0042 & $\begin{array}{c}47 \\
\alpha=144\end{array}$ & $4.5 \times 10^{.5}$ & 4.46 & 0 & 0 & 0 & 0 \\
\hline${ }^{23 x} \mathrm{Pu}$ & 17.12 & $\begin{array}{c}3.0 \times 10^{3} \\
\alpha=6.3 \times 10^{5}\end{array}$ & $3.0 \times 10^{-9}$ & $3.0 \times 10^{-4}$ & $6.3 \times 10^{5}$ & 1.76 & $6.2 \times 10^{-3}$ & 615.0 \\
\hline${ }^{239} \mathrm{Pu}$ & 0.062 & $\alpha=2.3 \times 10^{-5}$ & $2.8 \times 10^{\circ .4}$ & $2.8 \times 10^{-9}$ & $2.3 \times 10^{3}$ & 0.066 & $2.3 \times 10^{-3}$ & 2.28 \\
\hline${ }^{210} \mathrm{Pu}$ & 0.227 & $\alpha=8.4 \times 10^{3}$ & 0 & 0 & $8.4 \times 10^{3}$ & 0.029 & $4.4 \times 10^{-4}$ & 43.6 \\
\hline${ }^{241} \mathrm{Pu}$ & 103 & $\begin{array}{c}\beta=3.8 \times 10^{6} \\
\alpha=92\end{array}$ & 0 & 0 & 92 & 0.0014 & $4.8 \times 10^{-6}$ & 0.48 \\
\hline${ }^{237} \mathrm{~Np}$ & $7.1 \times 10^{-4}$ & $\alpha=26$ & 0 & 0 & 26 & 32.7 & $1.3 \times 10^{-6}$ & 0.13 \\
\hline${ }^{232} \mathrm{U}$ & 22.4 & $\alpha=8.3 \times 10^{5}$ & $1.7 \times 10^{-12}$ & $1.69 \times 10^{-9}$ & $8.3 \times 10^{5}$ & 0.24 & $8.2 \times 10^{.3}$ & 813.8 \\
\hline${ }^{23} \mathrm{U}$ & $9.6 \times 10^{.3}$ & $\alpha=8.3 \times 10^{5}$ & $1.1 \times 10^{-1.5}$ & $1.1 \times 10^{-40}$ & 357 & 1.29 & $1.9 \times 10^{.5}$ & 1.84 \\
\hline${ }^{235} U$ & $1.9 \times 10^{-6}$ & $\alpha=0.07$ & 0 & 0 & $6.8 \times 10^{-3}$ & 156 & $3.5 \times 10^{.10}$ & $3.5 \times 10^{-5}$ \\
\hline${ }^{233} \mathrm{U}$ & - & - & - & - & - & 1.3 & - & - \\
\hline $\begin{array}{l}{ }^{147} \mathrm{Pm} \\
\left({ }^{147} \mathrm{Nd}\right)\end{array}$ & $\begin{array}{c}927 \\
\left(8 \times 10^{4}\right)\end{array}$ & $\begin{array}{l}\beta=3.4 \times 10^{7} \\
=\left(3 \times 10^{5}\right)\end{array}$ & 0 & 0 & $\begin{array}{c}3.43 \times 10^{7} \\
\left(3 \times 10^{9}\right)\end{array}$ & $\begin{array}{l}0.0044 \\
(141)\end{array}$ & $\begin{array}{c}0.0013 \\
\left(3.7 \times 10^{3)}\right.\end{array}$ & $\left(3.7 \times 10^{3)}\right.$ \\
\hline${ }^{226} \mathrm{Ra}$ & 0.989 & $\alpha=3.7 \times 10^{4}$ & 0 & 0 & & 6.74 & $1.9 \times 10^{-3}$ & 138.9 \\
\hline \multicolumn{2}{|c|}{ Neutron Yield per fission: } & $\begin{array}{l}{ }^{232} \mathrm{U}=2 . \\
{ }^{233} \mathrm{U}=2 . \\
{ }^{235} \mathrm{U}=2 .\end{array}$ & \multicolumn{2}{|c|}{$\begin{array}{l}{ }_{238}^{23} \mathrm{Pu}=2.61 \\
{ }^{239} \mathrm{Pu}=2.89 \\
{ }^{442} \mathrm{Pu}=3.20\end{array}$} & $\begin{array}{l}m=3.10 \\
m=3.30 \\
m=3.43\end{array}$ & $\begin{array}{l}{ }^{248} \mathrm{Cm}=3 . \\
{ }^{209} \mathrm{Cf}=3.7 \\
{ }^{252} \mathrm{Cf}=3.7\end{array}$ & & \\
\hline
\end{tabular}




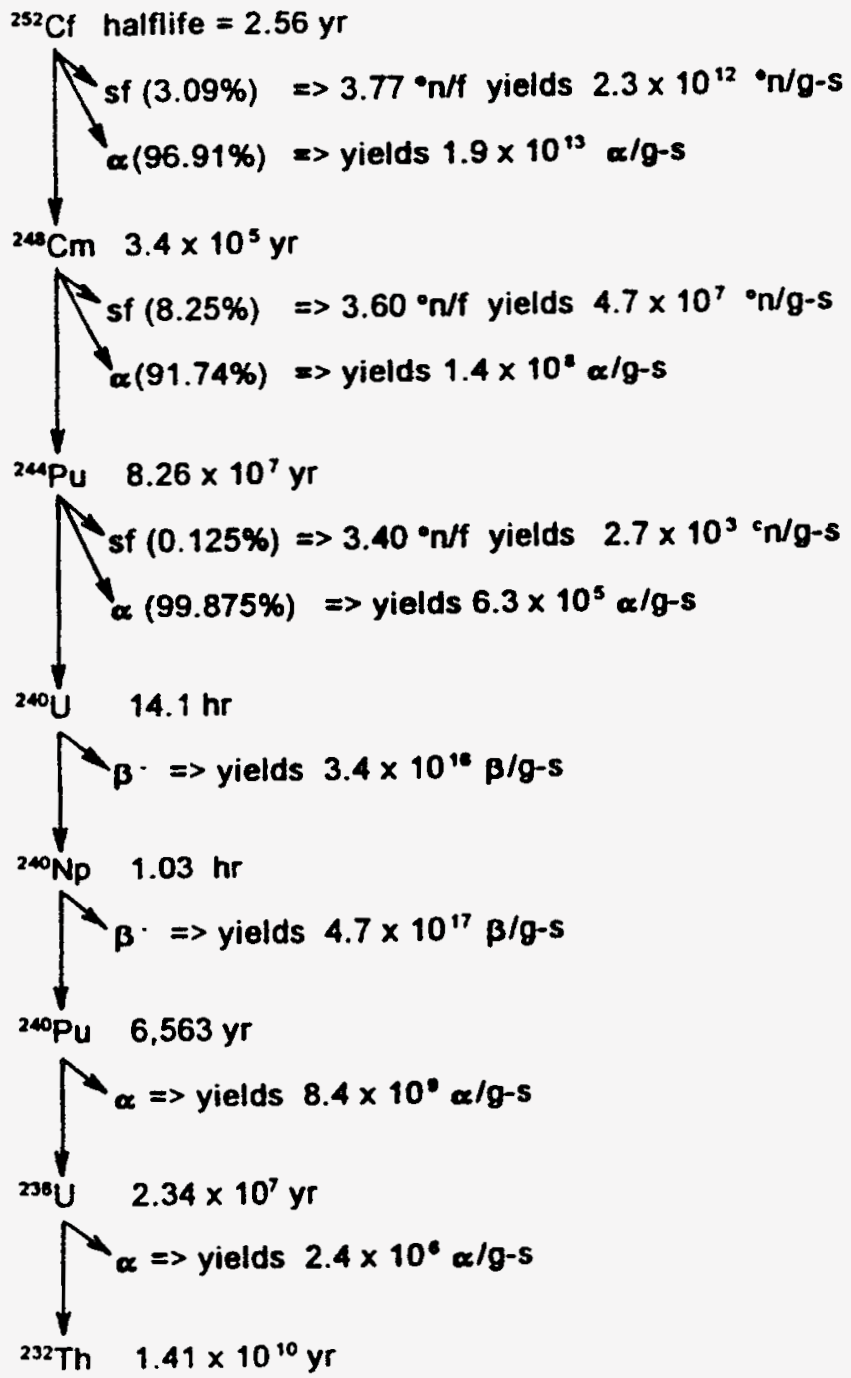

Fig. 13. Decay Sequence of ${ }^{252} \mathrm{Cf}$ 
Table 4. CH-TRU drums assayed for neutrons

\begin{tabular}{|c|c|c|c|c|c|c|c|}
\hline ATN & $\begin{array}{c}\text { Surface } \\
\text { gamma } \\
\text { dose } \\
\text { rate } \\
(\mathrm{mR} / \mathrm{h})\end{array}$ & $\begin{array}{l}\text { Fissile } \\
\text { Mass } \\
{ }^{239} \mathbf{P u} \\
\text { equiv } \\
\text { (mg) }\end{array}$ & $\begin{array}{c}\text { Passive neutrons } \\
\text { measured at } \\
\sim 1.5 \\
\text { Drum radii } \\
\left({ }^{\circ} \mathrm{n} / \mathrm{s}\right)\end{array}$ & $\underset{\substack{\text { Passive } \\
\text { neutrons } \\
\left({ }^{\circ} \mathrm{n} / \mathrm{h}\right)}}{ }$ & $\begin{array}{c}\text { Passive } \\
\text { neutrons } \\
\text { per 6 hr } \\
\text { work day } \\
\text { @ } 1.5 \\
\text { drum } \\
\text { radii }\end{array}$ & $\begin{array}{c}\text { Passive } \\
\text { neutron } \\
\text { dose @ } \\
\text { worker; } \\
\text { 28@ of } \\
\text { source } \\
\left({ }^{\circ} \text { n/day) }\right.\end{array}$ & $\begin{array}{c}\text { Worker } \\
\text { Dose Rate } \\
\text { with 2.5 } \\
\text { MeV } \\
\text { neutrons } \\
\text { (mrem/day) }\end{array}$ \\
\hline 1208 & $<1$ & 2 & $0.5 \pm 1.0$ & $1.8 \times 10^{3}$ & $1.1 \times 10^{4}$ & $3.1 \times 10^{3}$ & $1.0 \times 10^{-4}$ \\
\hline 1996 & $<1$ & 148 & $541 \pm 9$ & $1.95 \times 10^{6}$ & $1.2 \times 10^{7}$ & $3.4 \times 10^{6}$ & 0.16 \\
\hline 1631 & $<1$ & 2,700 & $(1.49 \pm .01) \times 10^{4}$ & $5.4 \times 10^{7}$ & $3.3 \times 10^{8}$ & $9.3 \times 10^{7}$ & 4.30 \\
\hline 1676 & $<1$ & 122 & $47 \pm 2$ & $1.7 \times 10^{5}$ & $1.0 \times 10^{6}$ & $2.8 \times 10^{5}$ & 0.01 \\
\hline 1817 & $<1$ & 143 & $2,150 \pm 14$ & $7.74 \times 10^{6}$ & $4.7 \times 10^{7}$ & $1.4 \times 10^{7}$ & 0.65 \\
\hline 1946 & 100 & 14 & $1,400 \pm 20$ & $5.1 \times 10^{6}$ & $3.1 \times 10^{7}$ & $8.7 \times 10^{6}$ & 0.40 \\
\hline 1374 & 180 & 23 & $(1.28 \pm .01) \times 10^{4}$ & $4.61 \times 10^{7}$ & $2.8 \times 10^{8}$ & $7.9 \times 10^{7}$ & 3.64 \\
\hline 749 & 25 & 45 & $(2.48 \pm .01) \times 10^{6}$ & $8.93 \times 10^{9}$ & $5.4 \times 10^{10}$ & $1.6 \times 10^{10}$ & 738.5 \\
\hline
\end{tabular}

Notes: 1 Curie $=3.7 \times 10^{10}$ disintegrations $/$ second; therefore, $1.0^{\circ} \mathrm{n} / \mathrm{s}=2.7 \times 10^{-5} \mu$ Curie CONCLUSION: For a glove box without neutron shielding, $\max$ acceptable passive neutron count from a single drum (to meet ALARA goal of $<0.40 \mathrm{mrem} / \mathrm{h}=2.4 \mathrm{mrem} /$ day) is $<2.6 \times 10^{4}{ }^{\circ} \mathrm{n} / \mathrm{s}$ 
Table 5. Average yearly maximum permissible neutron flux to meet ALARA goals of $500 \mathrm{mrem} / \mathrm{year}$ for a 1254 hour work year

\begin{tabular}{|c|c|}
\hline $\begin{array}{c}\text { Neutron Energy } \\
(\mathbf{M e V})\end{array}$ & $\begin{array}{c}\text { Flux } \\
\left({ }^{\circ} \mathbf{n} \mathbf{c m}^{2} \text {-sec }\right)\end{array}$ \\
\hline thermal & 107 \\
\hline 0.0001 & 80 \\
\hline 0.005 & 91 \\
\hline 0.02 & 45 \\
\hline 0.1 & 13 \\
\hline 0.5 & 4.8 \\
\hline 1.0 & 2.8 \\
\hline 2.5 & 3.2 \\
\hline 5.0 & 2.8 \\
\hline 7.5 & 2.7 \\
\hline 10 & 2.7 \\
\hline
\end{tabular}


Table 6. Transuranic radioisotopes in CH-TRU drums as listed in the SWIMS data base

\begin{tabular}{|l|c|c|c|}
\hline \multicolumn{1}{|c|}{ Isotope } & $\begin{array}{c}\text { Number } \\
\text { of } \\
\text { Drums }\end{array}$ & $\begin{array}{c}\text { Highest } \\
\text { quantity } \\
\text { in 1 drum }\end{array}$ & $\begin{array}{c}\text { Calculated } \\
\text { quantity } \\
\text { in drum }\end{array}$ \\
\hline Americum-241 & 40 & 105 Curie & 29.74 grams \\
\hline Americum-243 & 10 & 0.185 & 0.93 \\
\hline Berkelium-249 & 12 & 0.001 & $6.1 \times 10^{-7}$ \\
\hline Californium-249 & 1 & 0.002 & $5 \times 10^{-4}$ \\
\hline Californium-250 & 0 & - & - \\
\hline Californium-252 & 91 & 0.1 & $2 \times 10^{-4}$ \\
\hline Curium-242 & 3 & $2.42 \times 10^{-3}$ & $7.31 \times 10^{-7}$ \\
\hline Curium-244 & 281 & 8.09 & 0.10 \\
\hline Curium-248 & 0 & - & - \\
\hline Plutonium-238 & 14 & 34.8 & 2.03 \\
\hline Plutonium-239 & 147 & 0.982 & 15.84 \\
\hline Plutonium-240 & 9 & 1.37 & 5.96 \\
\hline Plutonium-241 & 10 & 224 & 2.18 \\
\hline Plutonium-242 & 5 & $3.9 \times 10^{-3}$ & 0.993 \\
\hline Promethium-147 & 0 & - & - \\
\hline Neptunium-237 & 28 & $8.93 \times 10^{-2}$ & 125.78 \\
\hline Radium-226 & 0 & - & - \\
\hline Uranium-233 & 135 & 0.2 & 20.83 \\
\hline Uranium-234 & 1 & $3 \times 10^{-4}$ & 0.05 \\
\hline Uranium-235 & 28 & $4.3 \times 10^{-5}$ & 22.63 \\
\hline Uranium-238 & 28 & $1.4 \times 10^{-3}$ & $?$ \\
\hline
\end{tabular}


establishment of a criteria for selecting specific drums in the inventory for beginning level, lowest risk repackaging activities (Table 7) in a glove box (described in Section 5). The analyses charted in Figs. 10 through 13 and Tables 1 through 7 necessitated evaluation of the physical effects of primary radiation hazards from radioactivity and radiotoxicity; the potential of secondary nuclear reactions such as alpha-neutron, neutron-gamma, and beta-x-ray effects; possible tertiary roducts; and the dynamics of decay chain equilibrium material relative to anticipated hazards in the waste material and mitigation of those hazards as specified in existing ORNL safety guidelines.

Design of the repackaging facility hinged in detail on the quantities and types of radiological material to be processed and the materials encountered in the repackaging process that could participate in a variety of reactions. Determining the level of hazards to be encountered has a major impact on facility design, facility cost-effectiveness, its safety and monitoring features for operator protection, and the selection of $\mathrm{CH}-\mathrm{TRU}$ drums to be processed.

As part of the repackaging facility design effort, HP, ALARA, and other industry-pertinent safety requirements and guidelines were extensively reviewed in order to develop operational system requirements. Also incorporated into the new PC-based data base developed by $\mathrm{M} \& \mathrm{C}$ are relevant data from the Solid Waste Information Management System (SWIMS) data base, Joe's Picture Book, and Resource Conservation Recovery Act (RCRA) closure activity data interpreted on the basis of findings summarized in Figs. 10 through 13 and Tables 1 through 7. These efforts received preliminary review by WEAF personnel, WMRAD personnel, and neutron physics experts to ensure that we had the best available data for design considerations. Although the new database was not complete, identifying the lowest risk set of drums did establish a design criterion and allow the repackaging project to proceed to the next phase of specifications for procurement and construction of the facility.

One early conclusion derived from these investigations is that CH-TRU waste at ORNL contains far greater hazards than are typical at other DOE facilities. For example, the radiotoxicity of several TRU isotopes is from 4 to 6 orders of magnitude more hazardous than plutonium-239 (Pu-239), which is used as the industry standard and given the value of 1 (Table 3). Consequently, the design of a fail-safe repackaging facility to handle these isotopes on a regular operating basis requires great attention to detail along with proper on-line detection and 
Table 7. CH-TRU drum selection criteria and selected drums for consideration for initial repackaging

\begin{tabular}{|c|c|c|c|c|c|c|c|c|c|c|c|c|}
\hline \multicolumn{13}{|c|}{ CH-TRU Inventory (all containers) } \\
\hline & & & & & SORT E & 3Y ATN & & & & & & -1 \\
\hline \multicolumn{2}{|c|}{ Tolal containers: } & & 2,614 & & & & & & & & & \\
\hline \multirow{2}{*}{\multicolumn{2}{|c|}{ No dose rale dala: }} & & 1701 & & & & & & & & 1 anol & - \\
\hline & & No content description: & $\frac{110}{755}$ & & \multicolumn{5}{|c|}{ \# of drums $<0.5 \mathrm{mrem} / \mathrm{hr}$ neulron } & & $\frac{1.909}{1.811}$ & --- \\
\hline \multicolumn{2}{|c|}{ No drum typo: } & & 108 & & & & & & & & & $\cdots-$ \\
\hline \multicolumn{2}{|c|}{ Overpacks (55-ga): } & & 49 & & \multicolumn{4}{|c|}{ \# of drums $<10.5 \mathrm{mrem} / \mathrm{hr}$} & & & 1.869 & - \\
\hline \multicolumn{2}{|c|}{ Overpacks (79-ga): } & & 393 & & \multicolumn{5}{|c|}{ \# of drums <20.5 - 10.5 mrem/hr } & & 208 & \\
\hline \multicolumn{2}{|c|}{ Odd conlainers: } & & 6 & & \multicolumn{5}{|c|}{ \# of drums <30.5 - 20.5 mrem/hr } & & 91 & $\cdots$ \\
\hline \multicolumn{2}{|c|}{ Contain llquids: } & & 825 & & \multicolumn{5}{|c|}{ \# of drums <50.5 - $30.5 \mathrm{mrem} / \mathrm{hr}$} & & 124 & \\
\hline \multicolumn{3}{|c|}{ Contaln lead (plgs, elc) } & 190 & & \multicolumn{5}{|c|}{ \# of dnums < $100.5-50.5 \mathrm{mrem} / \mathrm{hr}$} & & 79 & \\
\hline \multicolumn{3}{|c|}{ Contain HEPA fitters: } & 216 & $\dot{5}$ & \multicolumn{5}{|c|}{ \# of drums <200.5 - $100.5 \mathrm{mrem} / \mathrm{hr}$} & & 47 & - \\
\hline \multicolumn{3}{|c|}{ Conlaln compressed gas cyllnders } & 190 & & \multicolumn{4}{|c|}{ \# of drums $>200$ mrem/hr } & & & 21 & \\
\hline & & & & & & & & & lotal: & & 2,609 & \\
\hline & & & & & & & & & & & & \\
\hline & & \multicolumn{2}{|c|}{ Contalner Information } & \multicolumn{8}{|c|}{ Resurvey Info; Dose Rato (mr/hr) } & \\
\hline Old & Drum & Contalner & Measured & Resurvey Dato & & & Cor & ntact & & & & \\
\hline \multirow[t]{7}{*}{ ATN* } & ATN & Typo & Wght (lbs) & (Dato Pulled) & Gamma & Neutron & total & liq & HEPA & load & cyl & - General Dium Conditlon \\
\hline & 363 & $70 \mathrm{gal} O P$ & & $12 / 1 / 03$ & 0.1 & 0.1 & 0.2 & & & & & Dry Wasto Burnable \\
\hline & 411 & & & $11 / 24 / 93$ & 0.1 & 0.1 & 0.2 & & & & & LLW. Reclassified. X-Ray $11 / 10 / 85$ \\
\hline & 658 & $55 \mathrm{gal}$ SS & & $11 / 24 / 93$ & 0.1 & 0.1 & 0.2 & & & & & LLW. Reclassified \\
\hline & 888 & & & $11 / 24 / 93$ & 0.1 & 0.1 & 0.2 & & & & & LLW. Reclassified, X-Ray $11 / 10 / 85$ \\
\hline & 2254 & 55 gal SS & 140 & $12 / 11 / 93$ & 0.1 & 0.1 & 0.2 & $\underline{Y}$ & & & & Llquld In bottles $\&$ In pockots. Hool in buckot at $20^{\circ}$ \\
\hline & 2310 & 55 gal SS & 150 & $12 / 11 / 93$ & 0.1 & 0.1 & 0.2 & & & & & Dry solids, 55 gal ss drum \\
\hline \multirow[t]{10}{*}{$(0937-2)$} & 3767 & & & $11 / 24 / 93$ & 0.1 & 0.1 & 0.2 & & & $\mathbf{Y}$ & & Lead, rolled up sheet \\
\hline & 287 & & & $11 / 24 / 93$ & 0.2 & 0.1 & 0.3 & & & & & LLW. Reclassified, X-Ray $11 / 10 / 85$ \\
\hline & 355 & $55 \mathrm{gal}$ SS & 104 & $11 / 24 / 93$ & 0.2 & 0.1 & 0.3 & & & & & LLW. Drum Reclasssified \\
\hline & 524 & & & $11 / 24 / 93$ & 0.2 & 0.1 & 0.3 & & & & & LLW. Roclassified \\
\hline & 550 & 55 gal SS & 129 & $11 / 24 / 93$ & 0.2 & 0.1 & 0.3 & & & & & LLW. Reclassified \\
\hline & 647 & & & $11 / 24 / 93$ & 0.2 & 0.1 & 0.3 & & & $Y$ & & Lead suspected. Opaque Equip Can'T Be Clearly Pene \\
\hline & 648 & & & $11 / 24 / 93$ & 0.2 & 0.1 & 0.3 & & & $\mathbf{Y}$ & & Lead, suspect Opaque Equip Can'T Be Clearly Penell. \\
\hline & 769 & $55 \mathrm{gal}$ SS & 127 & $11 / 24 / 93$ & 0.2 & 0.1 & 0.3 & & & & & LLW. Drum Reclassfied \\
\hline & 1454 & & & $11 / 24 / 93$ & 0.2 & 01 & 03 & & & & & LLW, Reclas sified \\
\hline & 1882 & & & $11 / 24 / 93$ & 02 & 01 & 03 & & & & & Wasto. General Glove Box \\
\hline
\end{tabular}


continuous monitoring equipment. This emphasis is important so that a thorough understanding is established of the highly complex and broad range of extremely hazardous materials in the CH-TRU drums at ORNL.

\subsection{PHYSICAL CHARACTERISTICS}

As previously mentioned, drum contents were analyzed by viewing or collecting data from RTR videotapes, which supply excellent information on the physical characteristics of the drum contents. These tapes were generated by the WEAF facility as a visual record of the contents of individual drums. Some of the data has been evaluated and is available in the form shown in Fig. 14. In many other cases, the data is available only in facility notebooks.

The kind of information that can be seen in the RTR tapes is clearly shown in Fig. 14. The histograms produced from many such tapes provide a breakdown of typical drum contents: glass, plastic, paper, metal, rubber, machinery, bulk metal, sludge and soil, lead pigs, unspecified liquids, mercury, pressurized containers, and cans of packaged material such as melted plastic containing nuclear targets. Histograms of these materials were formulated on the basis of RTR tape examination, and surrogate waste drums were packed for initial testing to determine waste volume reduction by use of a 40-hp shredder. Typical volume reduction was determined to be about $85 \%$ with multiple passes through the shredder. Although the selected shredder was powerful enough to shred the 55-gal waste drums themselves, including most contents, the sizes of the shredded output pieces were generally in strips about 1.25 in. wide by several inches long and did not reduce volume significantly. Multiple passes through the shredder reduced the size of output pieces, yielding much reduced volume, but indicated that initial plans to install a shredder of this capability in a repackaging facility involved far more difficulties than benefits. To achieve a more homogeneous mixture of shredded wastes, a primary objective in the beginning of this project, a much smaller shredder yielding small output pieces was thought to be more effective in volume reduction, but such a shredder required sorting of input material to avoid damaging or destroying the unit.

Additional data generated by WEAF is real-time neutron emission data using the passiveactive neutron (PAN) device and the Active-Passive Neutron Examination and Assay (APNEA) 


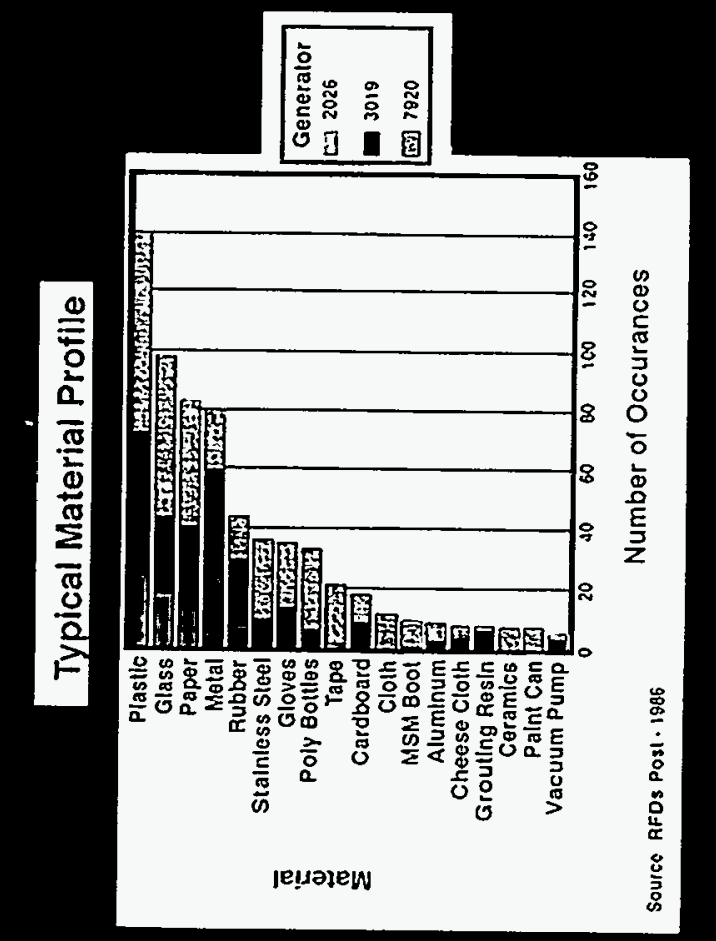

है

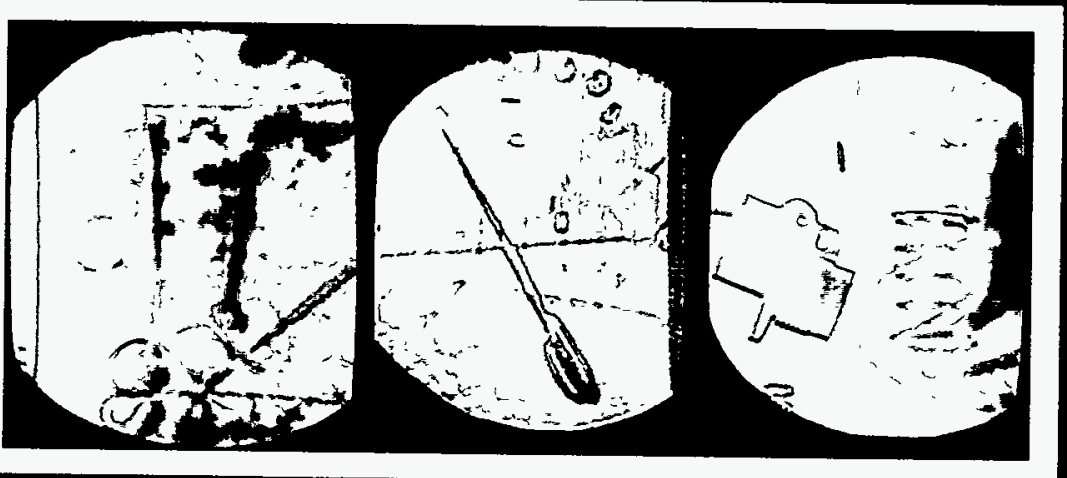


facility. The primary purpose of these diagnostic facilities has been to determine the quantity of fissile material contained in each drum. Data from these facilities also indicate neutron activity which is useful in anticipating dose rates to hands-on operators. This data needs to be integrated into one data base because it is of great importance to the design of a repackaging facility: handling neutron emitters above the dose rate levels listed in Fig. 13 requires major shielding and remote handling (both of which add significantly to design and operating costs).

The value of data like that shown in Fig. 13 is that it provides immediately useful insight into the visible characteristics of the waste for selecting the types of tools, machinery, and handling capability required to repackage and certify waste material to meet WIPP WAC. This data provided the basis for building a mock-up glove box for testing various concepts. During this project, physical content information and the mock-up facility were used to

1. evaluate the shredder for volume reduction,

2. provide a means of testing drum interface characteristics,

3. assess methods of drum unloading using a master-slave manipulator, and

4. provide early operations testing of the ergonomics of manipulating the various waste materials inside the mock-up glove box.

These activities will be described in Section 6 .

\subsection{RADIOLOGICAL CHARACTERISTICS}

From the M\&C-generated data base using compiled RCRA closure data, SWIMS data, RTR data from WEAF, and calculated data, a histogram (Fig. 11) was compiled to show that a large number of the CH-TRU drums display sufficiently low external surface dose rate to be considered for repackaging in a minimum glove box. However, external surface dose rate does not correlate with actual HP measurements of the waste packages at the time they were inserted in the drums, nor does it correlate with calculated quantities of the isotopes listed as contained in the drums (Table 4). Also, "intelligent packaging" was used to place hotter sources in the center of drums with surrounding material as shielding to reduce external surface dose rate. External surface dose rate does not translate into dose rate from alpha and beta emissions because these radiations do not penetrate the drum surface. Intense beta emitters (Table 1) can penetrate rubber 
gloves and produce secondary $\mathrm{x}$-rays in a variety of materials. Because most gamma radiation associated with alpha and beta decay is relatively low in energy, these emissions can be effectively blocked by the waste material itself and then become exposed once shielding material is removed. Similarly, neutron shielding by low atomic number material, such as plastic, very effectively reduces the neutron flux that can be a source of exposure once the plastic is removed. This case is most noticable with reactor targets placed in containers of melted plastic.

Consequently, external surface dose rate is insufficient as a criterion for selecting drums for repackaging. Each selected drum must be studied before it is opened to determine the specific hazards involved. Thus, the level of effort for safely handling and repackaging this material is much greater than simply dumping drum contents out in a glove box and sorting the material based on visual judgments. The hazards involved are far too complex for this simple approach.

\subsubsection{External Surface Dose Rate Data from WEAF}

The best available data on actual exposure to operating personnel is found in the ORNL WMRAD report on the RCRA closure activity. During that activity, drum external surface dose rate was measured and recorded. The dose rates received by two WEAF personnel spanning many months of continuous association with CH-TRU drums in which proximity to the drums was limited to about $10 \%$ of on-the-job time were compiled (Fig. 10) as an indicator of the dose rates likely to be received by repackaging personnel. However, exposure to personnel from un-emptied drums presents one set of criteria whereas handling drum contents presents another likely to be of much greater consequence to operators. Given the data shown in Fig. 10, unless appropriate precautions are taken, personnel exposures are anticipated to be unacceptably high.

\subsubsection{CH-TRU Drums in the SWIMS Data Base Sorted by External Surface Dose Rate Data from RCRA Closure Evaluation}

Integrating the RCRA closure data (Fig. 11) into the inventory data base provided a means of partitioning the drums into dose rate categories. Of the 2614 drums tabulated, 170 have no data and were partitioned as a separate category not to be considered for repackaging. Examination of this data showed that a large number of drums were of sufficiently low external surface dose rate to be considered candidates for repackaging. 
However, this data immediately indicates that any facility used for repackaging the lowest level activity $(<10.5 \mathrm{mrem} / \mathrm{h})$ is likely to require shielding for operators continuously on the job in close proximity to the drums. Further partitioning of this number of drums (1869) into lower level activity subsets reveals that several hundred drums are available as lowest risk drums. The drums selected depends not only on external surface dose rate but also on many other considerations composing the selection criteria. It is these criteria that dictate the design parameters for the repackaging facility. For example, if a selected drum displays an external surface dose rate of $1 \mathrm{mrem} / \mathrm{h}$, and operators can process the entire drum in $1 \mathrm{~h}$, anticipated total dose rate is in the range of $1 \mathrm{mrem} / \mathrm{h}$ per operator, about twice the 1997 ALARA goal. However, if drum contents have higher radiation fields, operator dose rates may be correspondingly higher; consequently, it is important to characterize the contained waste material as completely as possible.

\subsubsection{CH-TRU drums in the SWIMS Inventory Database by Building (Generator)}

To characterize the waste material beyond external surface dose rate, interviews with generators were conducted in search of data to more completely indicate various hazards, primarily radiation concerns, from generator waste streams. An example is the output from hot cell activities that produced waste material packaged as TRU waste. The criterion for CH-TRU waste is that the external surface dose rate of the waste drum be $<200 \mathrm{mrem} / \mathrm{h}$. Regardless of the activity displayed by material inside the drum, drums meeting this external surface dose rate are classified as $\mathrm{CH}$. Interviews with generators were very illuminating in that HP data listing measurements of individual packets in several drums examined exceeded this criterion, yet external surface dose rate was within the limit. This HP data indicates that many drums contain

dozens of packets that in combination, far exceed the criterion. Because no correlation was found between external surface dose rate and internal radioactivity, external surface dose rate is not considered an adequate indicator of exposures when handling the contained waste material. 


\subsubsection{Radioactivity of TRU Isotopes}

The TRU isotopes in the ORNL inventory in SWIMS were examined for basic characteristics. Fig. 8 is a summary of that data and indicates that small quantities of most TRU isotopes have high activities. Californium-252 ( $\mathrm{Cf}-252)$ is the most active neutron emitter, about 1 billion $\left(10^{9}\right)$ times more active than $\mathrm{Pu}-239$, the industry standard used for comparison. Curium-242 (Cm-242) is about $10^{5}$ times more active in alpha activity. Berkelium-249 (Bk-249) is a highly intense beta emitter, $10^{13} \beta / \mathrm{s}-\mathrm{g}$, whereas Pu-239 is not a beta emitter at all. Gamma activity is associated with nuclear particle emission (radioactive decay) and is relatively low in energy (in the keV range) and intensity, but particle energies range from $<1 \mathrm{MeV}$ to $\sim 6.5 \mathrm{MeV}$. These highly energetic particles produce a number of effects not immediately obvious from the figure. For example, nuclear recoil from radioactive decay tends to rapidly distribute daughters in random directions. Thus, the containment of an operational facility in which this material is handled must be fail-safe because this "popcorn" effect makes TRU isotopes extremely difficult to contain. Once out of containment, they are extremely difficult to confine and decontaminate. Another example is secondary reactions of alpha particles with other nuclei to produce neutrons, the $\left({ }^{0} n, \gamma\right)$ reaction, in the presence of low atomic number materials. The quantity of alpha emissions available from TRU isotopes makes, $\left({ }^{\circ} n, \gamma\right)$ not insignificant.

The SWIMS data base lists curie quantities of isotopes contained in CH-TRU drums. Calculations based on these quantities indicate discrepancies in cited activity or cited quantities of active material. Anticipated error in this data will strongly influence design approaches for a repackaging facility. An example is the very different shielding methods for neutrons and gammas. Neutrons require low- $Z$ material, such as high hydrogen content plastic, while gammas require high- $Z$ material, such as lead. Plastic is not effective in shielding gammas and lead is not effective in shielding neutrons. A facility designed to handle neutron emitters such as $\mathrm{Cf}-252$ in the quantities listed in SWIMS requires low- $Z$ material many inches thick.

\subsubsection{Radiotoxicity of TRU Isotopes}

Not only do the TRU isotopes under consideration display radioactivity, they also possess radiotoxicity characteristics that strongly influence the design of any repackaging facility. ORNL 
$\mathrm{HP}$ guidelines dictate the type of facility by the material being processed and use $\mathrm{Pu}-239$ as the standard, known as health equivalent plutonium (HEP). Isotopes listed in the CH-TRU drums exceed HEP by as much as 6 orders of magnitude. The material to be handled by a facility must be known before design parameters can be established. For the CH-TRU wastes, the SWIMS data base contains curie quantities of isotopes that can be used to calculate mass quantities. Mass quantities can then be used to determine the level of requirement a facility must meet.

Accumulation of various isotopes inside a repackaging facility poses the need to monitor and/or control buildup to prevent background off-set or saturation of radiation detector/monitors and the possibility of decontamination at intervals determined by build-up effects.

\subsubsection{Dose Calculation Data for TRU Isotopes}

Based on 1995 ALARA goals for personnel exposure, neutron, alpha, and gamma activities were calculated and related to inverse square geometries to determine anticipated dose rates per microgram of material. A microgram of any of the TRU isotopes listed as contained in CH-TRU drums cannot be seen by the human eye. Thus, the closeness of a worker's hands to minute quantities of TRU isotopes is one model for exposure, and whole-body exposures received by workers in body contact with the walls of the facility is the second model (Table 3 ). The vast range of exposures at a distance of $1 \mathrm{~m}$ and at $3.2 \mathrm{~mm}$, the latter being the approximate distance of a finger and thumb to the material through a glove box glove, indicates that ORNL TRU isotopes present unacceptable exposures from both neutron and gamma radiations. This data indicates that any hands-on repackaging facility must incorporate sophisticated and accurate nuclear radiation detection/monitoring equipment continuously on-line, and must have procedures for quickly handling all "hot" materials discovered by this equipment.

To remain within ALARA goals for a 240-day work year, workers can receive no more than $2.7 \mathrm{mrem} / \mathrm{day}$, or $0.45 \mathrm{mrem} / \mathrm{h}$ for a 6-h workday if averaged. This level of exposure is quite low by nuclear industry standards of the past and is approximately five times higher than natural background dose rates. DOE nuclear exposure standards permit ten times the accepted whole body dose rate to extremities. Thus, maximum continuous exposure to extremities permitted by DOE standards is much higher than ALARA goals. DOE standards permit cumulative whole 
body exposures of $5000 \mathrm{mrem} / \mathrm{year}$ (13.7 times ALARA goals) and 50,000 mrem/year for extremities (137 times ALARA goals). Using either DOE or ALARA standards, Table 3 is helpful in anticipating exposure dose rates from detectable activities. However, simply comparing quantities of radioisotopes listed on generator documentation or as shown in data bases is inadequate in anticipating the actual activities likely to be encountered during repackaging. The quantities of isotopes are time-dependent and decay to different radioisotopes that display different characteristics.

\subsubsection{Decay Sequence for $\mathrm{Cf}-252$}

All TRU isotopes radioactively decay and do so at different rates. As a result of the decay process, the original quantity of isotope decreases asymptotically toward zero. After about 10 half-lives, less than 0.001 of the original material exists. However, in decaying, daughters are produced that increase to equilibrium quantities that are also time-dependent. Daughters display different characteristics. For example, $\mathrm{Cf}-252$ does not meet the TRU criterion requiring a half-life of $>20$ years; however, Cf-252 is a highly radioactive substance that decays to $\mathrm{Cm}-248$ which does meet the TRU lifetime criterion. The difference in specific activity of these isotopes is such that the higher activity californium decays quickly but becomes curium that remains for more than $10^{5}$ years at lower activity. Fig. 13 illustrates that each isotopic decay sequence must be understood, and the age of the drum to be repackaged must be known. Then a prediction of the isotopic content and where in time the radioactive contents of the drum actually are at the time of repackaging allows anticipation of the radioactive characteristics of material in the drums. Note that $\mathrm{Cf}-252$ is not characterized as a beta emitter, yet two of its daughters are intense beta sources. Because beta activity is not detectable outside the drum's surface, predicting such activity before drums are opened is important in anticipating dose rates. Table 2 is just one example characteristic of all TRU isotopes and illustrates that these isotopes present a complex set of problems. 


\subsubsection{Assay of CH-TRU Drums}

One objective of WEAF operation is probing the interiors of drums with known source neutrons to determine the quantity of fissile material contained in the drums. In developing this diagnostic capability, several ORNL CH-TRU drums were examined. Table 4 illustrates the range of capability of this instrumentation and the complexity presented by the data. For example, the first five drums listed by ATN, which are in the set of drums identified as lowest risk and potentially suitable for repackaging in the minimum glove box, display identical external surface dose rates. However, the fissile mass ranges from 2 to $2700 \mathrm{mgm}$, and the range of measured passive neutron emitted each second spans 4 orders of magnitude.

Based on the calculated maximum allowable emission rate to remain within ALARA goals, $2.6 \times 10^{4} \mathrm{n} / \mathrm{s}$, only ATN 1208, 1946 and 1674 are acceptable candidates for repackaging in a minimum glove box. Table 4 illustrates the difficulty in using only external surface dose rate as an acceptance criterion and also demonstrates that external surface dose rate is not a predictor of neutron activity. ATN 749 displays only one-fourth of the external surface dose rate of ATN 1946 but yielded 3 orders of magnitude more neutrons. Thus, ATN 749 is an extremely hazardous drum that is not recommended for repackaging in a minimum glove box. Note that ATN 749 yielded far less fissile material than ATN 1631, yet it is a significantly higher neutron source, which indicates that the diagnostic data is suspect or that nonfissile sources of neutrons are contained in the waste material in this drum. Either outcome indicates the difficulty in establishing a definitive acceptance criterion while clearly indicating the need for continuous neutron detection/monitoring equipment as an integral capability of the repackaging facility. Note also that of the five drums listed in this figure as acceptable in the lowest risk set for neutrons $(<0.5$ $\mathrm{mrem} / \mathrm{h}$ ), only three are acceptable on the basis of neutron emission analysis. If this $20 \%$ factor holds for the entire CH-TRU inventory, the lowest risk set may be reduced from 1869 drums to about 1121. Consequently, passive neutron data for each drum is vitally important in determining the cost-benefit factors in any repackaging facility. 


\subsubsection{Neutron Emission Rate}

Resolving the nature of neutron dose rate relative to worker exposures proved to be a very difficult problem. The primary difficulty is recognizing that dose rates are a function of neutron energy and flux. Resolving neutron flux into energy increments allowed establishment of a range of values as a guide in evaluating potential dose rates if the passive neutron count from $\mathrm{CH}-\mathrm{TRU}$ drums is known. Further difficulties were recognized in the effect of neutrons in the body and their tendency to lose energy in elastic and inelastic collisions with nuclei resident in the body. Continual reduction of energy means a continually declining dose rate, as illustrated in Table 5. However, neutrons are produced as fission products, and are generally in the 1 to 2.5 $\mathrm{MeV}$ range, making this energy range of most importance when considering safe levels of exposure. As neutron energy declines toward zero, the probability of absorption changes toward maximum absorption at the thermal energy resonance peak. Also, the half-life of neutrons $(\sim 12.5$ min) is sufficiently long that neutron energy can be completely absorbed in the body, but if radioactive decay results before absorption, the beta particle, proton, and associated gamma radiation resulting from decay pose additional exposures of a different nature. As a guide for translating passive neutron count to dose rate, Table 5 was constructed from National Bureau of Standards data and gives the recommended limit of $\sim 3^{\circ} \mathrm{n} / \mathrm{cm}^{2}-\mathrm{s}$ in the 1 to $2.5 \mathrm{MeV}$ energy range as a partitioning criterion. Thus, drums above this limit are not recommended for consideration for repackaging in a minimum glove box. Those drums with less than this quantity of passive neutron emission may be considered, but further investigation into generator waste streams is recommended to provide insight into the possibility that neutron shielding may be in place. Because the interior of CH-TRU drums consists of unknown source terms, unknown shielding material, and unknown shielding configurations, no calculations can predict internal neutron activity. Consequently, drums that meet this neutron emission criterion should be opened only with properly functioning neutron detection/monitoring equipment in place.

\subsubsection{TRU Radioisotopes in CH-TRU Drums as Listed in the SWIMS Data Base}

Isotopes listed in SWIMS are tabulated in Table 6 for a selected set of drums with $<20 \mathrm{mrem} / \mathrm{h}$ external surface dose rate. This data relates listed isotopes to the number of drums 
containing the isotope, along with the maximum curie and mass content of stated isotope in the drum. Fig. 11 provides a convenient chart for quickly assessing the number of drums meeting the external surface dose rate criterion with SWIMS-derived quantities of active material. For example, 56 drums with uranium-238 (U-238) and uranium-235 (U-235) are likely to be of sufficiently low risk that they may be the first drums selected for repackaging. Referring to Table 1, the specific activity of uranium-233 (U-233) indicates that the 135 drums listed as containing this isotope can be anticipated to contain sources yielding $<10^{9}$ alpha particles/s. Although this is a relatively high alpha source, repackaging of these drums is likely to pose acceptable risks for a properly functioning minimum glove box with detectors and monitors in place and workers who are cognizant of potential hazards and their rapid mitigation.

Consequently, each drum accepted into the repackaging facility must be studied to gain a high confidence in understanding what to expect when the drum is opened.

Neutron problems have been discussed in detail in the foregoing, which leaves only pointing out that the 91 drums listed as containing Cf-252 are likely to be unacceptable for repackaging in a facility without substantial neutron shielding and remote handling/manipulation capability. Determination of actual exclusion must be based on identification of isotopes present and decaying of isotopes from time of packaging. The drum listed as containing $0.1 \mathrm{Ci}$ of $\mathrm{Cf}-252$ presents a source term of $\sim 4 \times 10^{9} \mathrm{n} / \mathrm{s}$, a deadly source of neutrons for workers close by.

Drums containing Americium-241 (Am-241) pose radiation risk hazards of higher magnitude. The drum listed as containing $105 \mathrm{Ci}$ of Am-241 is a source term of $\sim 4 \times 10^{12}$ alphas $/ \mathrm{s}$ with an average alpha particle energy of $\sim 5.5 \mathrm{MeV}$. Such an intense source of high-energy alphas presents the potential for secondary neutrons via the $\left(\alpha,{ }^{\circ} n\right)$ reaction. This quantity of Am-241 is also a source of gamma radiation at $\sim 29 \mathrm{keV}$. The alpha radiation is not detectable in external surface dose rate measurements, and the gamma radiation is sufficiently soft to be effectively shielded by waste material. Thus, opening such a drum is likely to reveal intense radiation sources and is not recommended for a minimum glove box. 


\subsubsection{CH-TRU Drum Selection Criteria and Selected Drums for Consideration as Candidates for Initial Repackaging}

The compiled database, TRUGAB1, incorporates the available data from the several sources previously discussed and provides a means of partitioning $\mathrm{CH}$-TRU drums by various attributes. The first page of this 74-page printout is presented as Table 7, which lists the selection criteria utilized in examining the data for 2614 containers of CH-TRU wastes. Considering only 55-gal drums (i.e., excluding those containing 30-gal drums), 2103 drums remain for consideration. Employing an acceptance criterion of $<0.5 \mathrm{mrem} / \mathrm{h}$ neutron, and specifying that the drums contain no high efficiency particulate air (HEPA) filters (to inhibit inclusion of concentrated fines), no lead (to inhibit inclusion of unknown radiation source terms that may spill), and no compressed gas cylinders (to inhibit inclusion of containers that may explode and rupture the alpha barrier by breaking a glove or window) brings the number down to 1274 that contain free and/or contained liquids, dirt and sludge, bulk metal, solid wastes, and other waste material. If we eliminate the drums that exhibit a gamma dose rate $>10.5 \mathrm{mrem} / \mathrm{h}$ total dose rate from all sources, 990 drums remain as potential candidates for repackaging in a minimum glove box. However, each drum selected should be given thorough, independent study to determine its individual characteristics.

\section{CHARACTERIZATION AND CERTIFICATION TO THE WIPP-WAC}

\subsection{NATIONAL TRU WASTE CHARACTERIZATION PROGRAM}

This section covers the requirements and the processes for characterizing CH-TRU waste so that it can be shipped to WIPP for disposal. A WIPP Disposal Decision Plan (DDP) has been devised by the DOE Carlsbad Area Office, which is coordinating disposal of TRU waste from all the DOE sites. In Fig. 15, the critical path is shown by the bold line starting at the compliance certification milestone and ending at the DOE's Secretary's decision to operate WIPP.

With respect to this critical path, there were three major milestones related to characterizing TRU waste, which are shown by the bold arrows feeding it into this schedule. The first milestone shown is a compliance package that will be submitted to the U.S. Environmental 


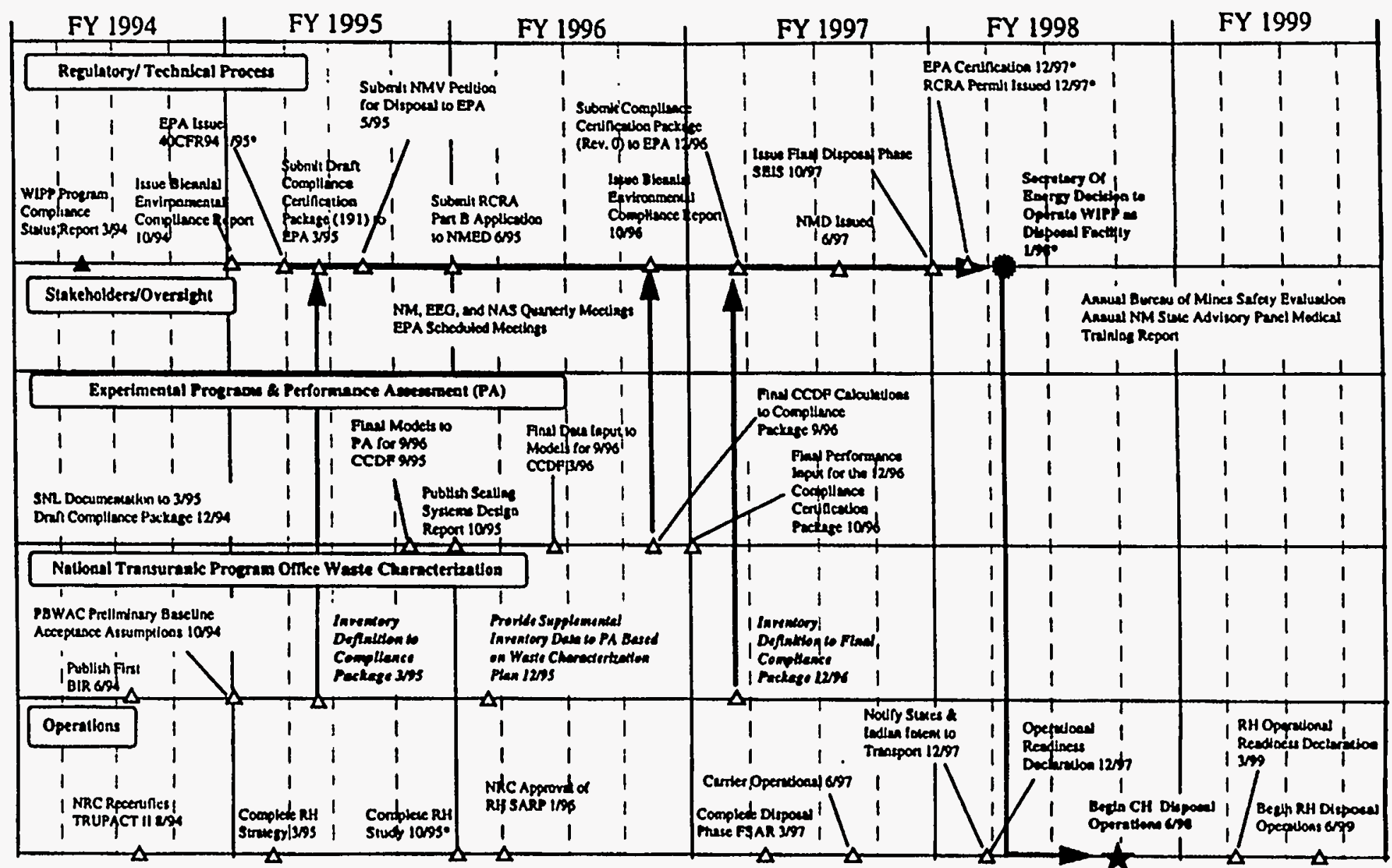

Fig. 15. WIPP disposal decision plan. 
Protection Agency (EPA) for use in verifying whether the no-migration determination, the Part $B$ RCRA permit, and other regulatory issues are addressed in each site's data inventory. The other data packages required from each of the DOE generator/storage sites must be delivered to the National Transuranic Program Office (NTPO) on the schedule shown in the figure.

These data packages are all based on the development of process knowledge, which has to describe the inventory of ORNL's TRU waste by legacy records and by new physical characterization studies. Because these milestones are tied directly into this critical path, it is very important for each site to characterize its TRU waste, using legacy record process knowledge as the first step. The national TRU waste characterization program has developed a process that all DOE sites must follow in characterizing their waste; major elements of this process are shown in Fig. 16. The first steps require organization of legacy information by describing the physical, chemical, and radiological characteristics into quantifiable groups of similar content. Similar content waste drums are combined and assigned waste matrix codes as defined in the WIPP TRU Waste Baseline Inventory Report (WTWBIR), which groups by waste profile. These waste streams are certified by WIPP and are shipped to WIPP in accordance with limited quantities criterion. For example, ORNL may have to supply a specific waste stream to fill a particular part of the WIPP facility, whereas INEL or Rocky Flats may have to supply a completely different waste stream. All the details of these activities are yet to be determined and are tied into the management system for loading the WIPP.

As soon as various waste profiles have been identified, this data is fed directly into the performance assessment calculations that are being conducted by Sandia National Laboratories. After this initial submittal of information, waste evaluation will continue to improve the data, which will be accomplished by physical examination in a characterization facility and other activities that are performed using NDE at WEAF. Once this information is collected, the empirical data can be compared with process knowledge data to ensure that they agree. When all the facilities information is collected and analyzed at Sandia National Laboratories, a revised waste acceptance criteria may be issued. In this manner, the revised WAC has been developed 


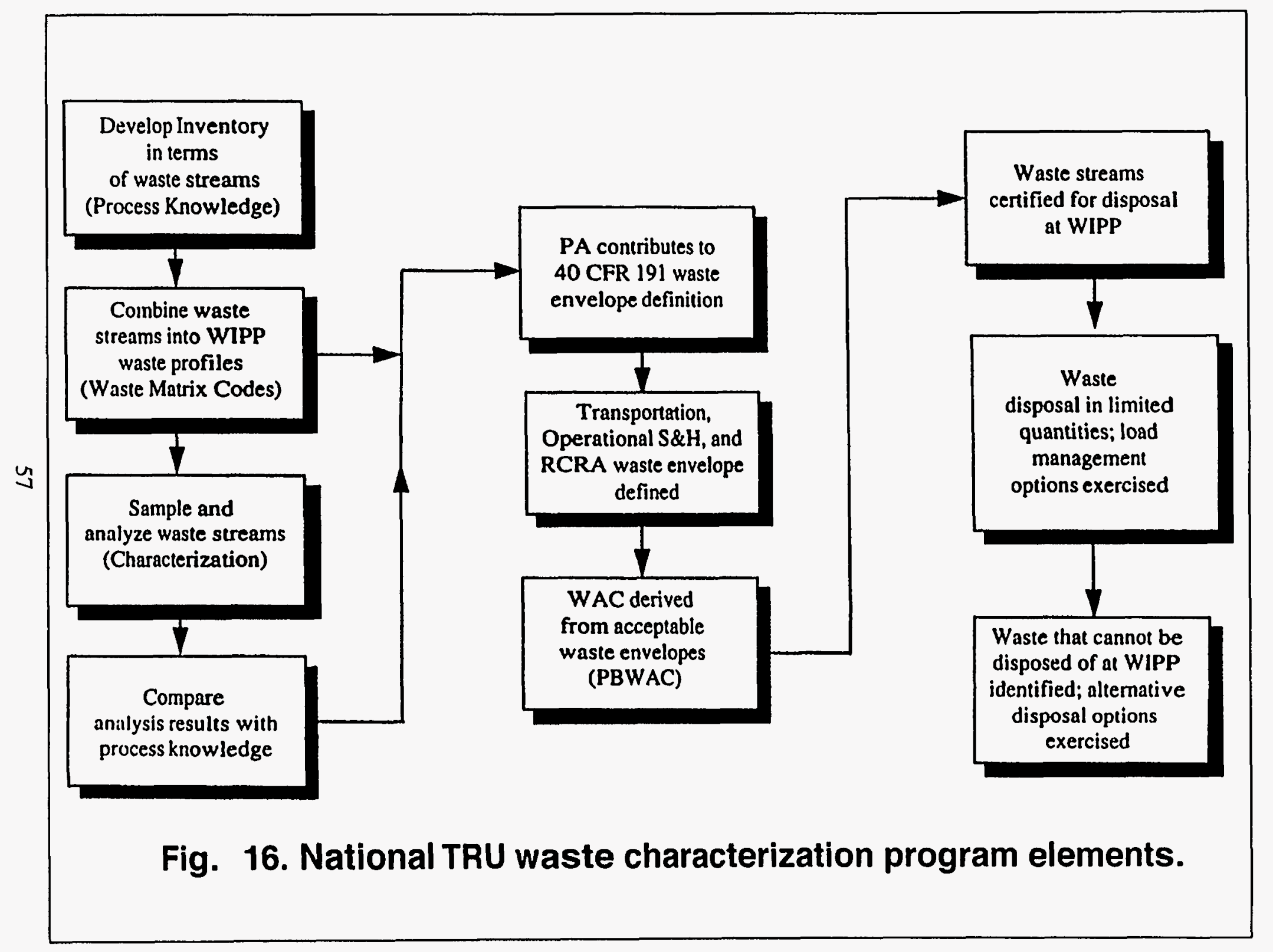


into a performance base waste acceptance criteria (PBWAC). Finally, certain waste will not be accepted at WIPP. WIPP will have to determine other alternatives, which may include treatment of these waste streams that fall outside the PBWAC.

\subsection{ORNL TRU WASTE CHARACTERIZATION/CERTIFICATION}

This section summarizes requirements for characterizing ORNL's CH-TRU waste for shipment to WIPP and ORNL's capabilities and activities to date.

The objective of the ORNL TRU waste characterization program is to collect waste inventory data in accordance with the quality assurance plan approved by the national program. This quality assurance plan, if executed properly, provides a defensible data base that will support

WIPP's regulatory compliance program. In addition, it creates, in the development of the process knowledge, a paper trail that will be auditable and defensible in any of the regulatory audits or surveillances that WIPP might conduct at any or all of the sites that anticipate certifying waste.

There are several TRU waste characterization programs that could be conducted at ORNL. The first step in developing characterization data is to compile all legacy process knowledge, which would necessitate the retrieval of as much relevant data and documentation as possible. Some of this work has already been done during this project (Section 3 ) and there are similar activities in progress by WMRAD for Radiochemical Engineering and Development Center (REDC) facilities. In years past, various subcontractors have conducted similar studies; however, this information is not organized according to WIPP requirements of identified waste streams or defining waste profiles that can be assigned a waste matrix code.

A second effort would be to develop a certification program for WEAF in accordance with the TRU Waste Characterization Quality Assurance Program Plan (QAPP). For WEAF to obtain this certification authority, the WIPP Waste Acceptance Criteria Certification Committee (WACCC) would have to evaluate and audit its equipment and procedures. It is also necessary to have a verification program in place, which would require that the information that WEAF is generating from nondestructive assay and examination be verified through visual characterization and some type of direct assay. 
A third program that should be implemented at ORNL is repackaging of CH-TRU drums. The objective of these efforts would be to remove WIPP-nonconforming items such as aerosol cans, to remove particulates in excess of the allowed limits, and to treat excess liquids. Containers or packages inside the drums could also be punctured, thus allowing a higher wattage to be transported within the guidance of TRU PAC-II. It may also be necessary to repackage drums to eliminate excessive void volume because WIPP could very well refuse drums that are not efficiently packaged. Another, and probably most important reason to have a characterization facility would be to implement a sample analysis program to verify ORNL process knowledge.

Process knowledge, again, which is the first step that has to be completed, will be considered by the regulators. The DOE Carlsbad Area Office has stated that the EPA is very interested in visiting the five major sites within the DOE complex to observe, audit, and survey each facility's process knowledge. The ready availability of defensible documentation with respect to process knowledge will definitely be beneficial in minimizing characterization efforts that would have to be performed in a glove box or hot cell facility. Good legacy records would minimize the collection of data by sampling and analysis, if the empirical data agrees with process knowledge. Also, certification of waste streams developed through this process knowledge is much more defensible when applied to a large number of drums, (i.e., if a good paper trail is auditable, regardless of whether it is EPA, the state, or the WACCC at WIPP inspecting, good data will raise the confidence level of the regulators and WIPP personnel). If empirical data does not agree with process knowledge, there will be more QA required to certify these waste streams. If a poor job is done in documenting process knowledge, characterization efforts will increase considerably. Certification by individual drums could very well be required as opposed to certification of waste streams that are representative of many drums. Because of the near-term milestones associated with the national TRU program, clearly a good strategy for meeting them is to aggressively pursue the recovery of as many generator records as possible. Although it may be argued that ORNL's research activities complicate such efforts, it has been our experience that there is more valuable data to gather. Interviews of facility operations personnel and the various research personnel involved revealed a surprising amount of data in facility records and personnel logbooks. It cannot be stressed enough that these activities must be performed as soon as 
possible, mainly because of the threatened loss of valuable people who have packaged the waste and been involved in the various processes. These people are the most likely to leave because of decreasing nuclear research funding and natural retirement attrition. A thorough, compiled information base will allow the better development of both a characterization program and a characterization facility.

There are three categories of information required for the compliance program and characterization program at WIPP: physical waste identification, chemical description, and radiological description.

Physical waste type can be derived from process knowledge and subsequently verified nondestructively by RTR performed at WEAF. Similarly, opening drums and examining the contents could be used to verify both the RTR and the process knowledge as well as to verify the various waste matrix codes. Drum opening would also be required for puncturing any sealed containers of more than 1-gal capacity (or as specified by current WIPP-WAC). The most important point to be made is that individual drums can be classified as belonging to various waste streams and it is the waste streams that are proposed to be certifiable to WIPP, not the individual drums.

The second category of information needed for WIPP is a chemical description, which preferably would be obtained from process knowledge and spot verification. A major part of the implementation of a characterization program is the gas sampling analyses of both drum headspace and inner containers having more than $250 \mathrm{ml}$ of headspace gases. This gas analysis data would be used to confirm the existence of named constitutes or to identify any new ones, primarily volatile organic compounds (VOC), semi-VOC, and compounds such as methane and hydrogen. A core sample must be taken if the drum contains sludges or soils that have been packaged in either one or more containers; sample and analysis for VOC, semi-VOC, and RCRA metals.

The third type of information required in a characterization program is radiological data. This information will be obtained in part from process knowledge and verified through nondestructive radiological assay at WEAF. Other sources of radiological information are hot cell smears and the records of generator facilities, which can be integrated with the WEAF data. 
Repackaging and characterization inside a glove box hot cell facility will allow samples to be taken and evaluated at radiological analytical laboratories.

HP radiological container information is also required by WIPP. Specifically, external surface dose rate and contamination levels are required. WEAF could also make a determination of the $\mathrm{Pu}-239$ fissile gram equivalent internal heat generation rates.

To meet these WIPP-WAC requirements, one of ORNL's principal needs is a facility in which the necessary characterization tasks can be performed. The principal objective of this project has been to rectify this situation consistent with the national TRU milestone schedule.

The DOE facilities are required to develop site-specific quality assurance project plans $\left(\mathrm{QAP}_{\mathrm{J}} \mathrm{P}\right)$ according to the guidelines set forth by the national TRU waste characterization quality assurance program plan (QAPP), which is specifically for CH-TRU waste. The QAP $_{\mathrm{J}} \mathrm{Ps}$ bridge the gap between the requirements of the national program and the sites by allowing the sites some flexibility in optimizing their individual programs. With the implementation of the Quality Assurance (QA) Program at ORNL, a methodology will be provided to obtain defensible data for regulators and for WIPP. ORNL is currently developing a $\mathrm{QAP}_{\mathrm{J}} \mathrm{P}$ and anticipates that implementation will begin by about September 1995 .

At ORNL, there is currently a lack of compiled process knowledge. There is some information that has been compiled to date, some of which was described in Section 3. Some of the data that has been generated is being used in the facility design for processing the CH-TRU drums. In addition, there is a lot more information that is needed to establish an ORNL process knowledge data base that will be used in doing both the performance assessment (PA) model and the WIPP compliance program, before WIPP is opened. The WTWBIR, based on individual site inventory reports, is the data base that will be used by both the PA model at Sandia and by WIPP to complete their compliance packages. These national requirements impose an urgency for the considerable amount of information that will be required.

There are no facilities at ORNL to perform visual examination, repackaging, or contents verification using sampling and analysis. A solution to these deficiencies can be found by simultaneously expanding legacy information retrieval and committing to the construction and operation of a characterization facility. This solution would involve completing all appropriate 
documentation: quality assurance project plan, revised or new procedures at the generator facilities and WEAF, inventory work-off plans, TRU waste program plans, plus all the requisite documentation for these tasks. Compilation of process knowledge in existing data bases with any additional documentation that is available at the legacy generator facilities is a must. Concurrent with these activities, construction of a characterization facility by the use of existing ORNL facilities would allow completion of the characterization tasks required to meet national TRU program schedules. Such a facility could be designed so that fairly inexpensive glove box enclosures could be used to start characterization operations soon. As need and experience were established through characterization operations, the facility could be expanded to process the more difficult $\mathrm{CH}-\mathrm{TRU}$ drums that are known to exist in the inventory.

Implementation of a certified characterization program, as just described, would have to follow the guidelines set forth by the ORNL QAP ${ }_{\mathrm{J}} \mathrm{P}$ for $\mathrm{CH}-\mathrm{TRU}$ waste. Once this document is written, WIPP approval through audits and surveys could be solicited to ensure that ORNL's activities meet requirements. In addition to the $\mathrm{QAP}_{\mathrm{J}} \mathrm{P}, \mathrm{ORNL}$ will have to implement a TRU PAC-II so that the TRU waste can be transported to WIPP. Its development, implementation, and approval typically require one to two years. INEL and Rocky Flats are the only sites in the country that can currently use TRU PAC-II.

In summary, there are a lot of tasks that must be completed if ORNL is to ship CH-TRU waste to WIPP by June 1998. Other DOE site experience in the activities discussed in this section supports the conclusion that recovery and compilation of process knowledge, as started for this project, is pivotal to all ORNL waste disposal goals. These activities will provide the documentation for both the disposal decision plan milestones in December 1995 and 1996 and the pending EPA review. It is also apparent that ORNL needs a facility to verify and supplement what legacy records are available. In addition, it is an unavoidable fact that a facility will be needed to repackage any $\mathrm{CH}$-TRU drums that do not meet WIPP requirements. Furthermore, because the two activites will compliment each other, close coordination between the recovery of process knowledge and the design of a characterization facility is imperative. 


\section{RECOMMENDED DESIGN FOR PHASED GLOVE BOX ENCLOSURE}

Section 2 described the evolution of information derived from legacy inventory analysis, design studies, and benchmarking with other DOE site facilities. This information provided the design team with insight into better methods of accomplishing the objective of providing the most cost effective facility for reprocessing $\mathrm{CH}-\mathrm{TRU}$ drums. Two basic changes were made to our initial proposal that, along with a myriad of small changes, will allow the confident recommendation of a workable design for this facility. The first major redirection was the change in location for constructing the glove box facility to the second story of Building 3525 instead of the basement. This change will provide a considerable savings in both the design of the glove box and the modifications of the building. The second improvement was our ability to quantify a design approach to a phased facility. It is now thought that initial facility capabilities could be relatively inexpensive and still provide the ability to process a significant number of drums. Furthermore, such a facility could be expanded, retrofitting the initial facility. This ability to phase the facility has come about because of the greater floor space and ceiling height on the second floor.

\subsection{FACILITY REQUIREMENTS}

Requirements for the phased CH-TRU facility process enclosure, or glove box, are

1. ability to load, unload, reseal, and decontaminate 55-gal drums that are to be processed in the facility;

2. use of the existing space and facilities in Building. 3525;

3. provision of secondary containment of the CH-TRU process activities from other Building 3525 activities; and

4. provision of fail safe alpha containment and limited beta/gamma shielding.

The facility to be developed must have adequate space for the characterization and repackaging process, provide for routine internal decontamination, and be designed ergonomically; in addition, the overall operation needs to be cost-effective. The facility must comply with all federal, state, and local regulatory requirements, and to maximize worker safety, will use proven industry 
guidelines and standards for process enclosures. In all plans and design, a phased approach to allow for future expansion of the facility for processing more radiologically hazardous drums will be provided.

\subsection{FACUITY FEATURES}

Figs. 17 through 20 show various views of the basic glove box enclosure installed on the second floor of Building 3525. The system incorporates a unique device for feeding in a 55-gal drum overpacked into a shielded sub-enclosure in such a way that we can dock 55-gal drums through the process enclosure and obtain a leak-tight, double O-ring seal. Once the incoming drum has been secured into the glove box enclosure, a mechanism inside the drum-shielded sub-enclosure elevates the 55-gal drum into the glove box so that the lid can be removed. Following removal, a master slave manipulator (Fig. 20) can be used to remove the contents so that each item can be examined. During the unloading operation, portable radiation monitors will be used to identify and exclude contents too hot to process in the glove box. As the drum is unloaded, contents to be processed, sampled, and characterized are manipulated through glove parts down the process line (Fig. 20). At the end of the process line, a drum-out system (similar to the drum-in system) seals a new 55-gal drum to the bottom of the glove box. This systems allows the processed materials to be bagged out into the new drum, which contains a PVC liner and bag. In this condition, the drum can then be lowered out of the glove box and the bag sealed off and trimmed, after which the new drum containing the repackaged material can be removed from the glove box. Fig. 20 shows other features of the basic glove box, for example, a $1 / 2$ ton hoist inside the enclosure to allow for the removal of items from the drum that are too heavy for the manipulator. A cost estimate for this basic glove box just described is provided in Table 8 . The work breakdown structure that was constructed to generate the cost estimate is provided in Table 9.

A conceptualization of an addition to the basic glove box, which has harder shielding, expanded master-slave capability, and the capability to open difficult drums, is shown in Figs. 21, 22, 23, and 24. Rapid transfer ports would be used to remove any hot items pulled out of the drums. Such items would be immediately loaded in the port, which would be sealed off, 


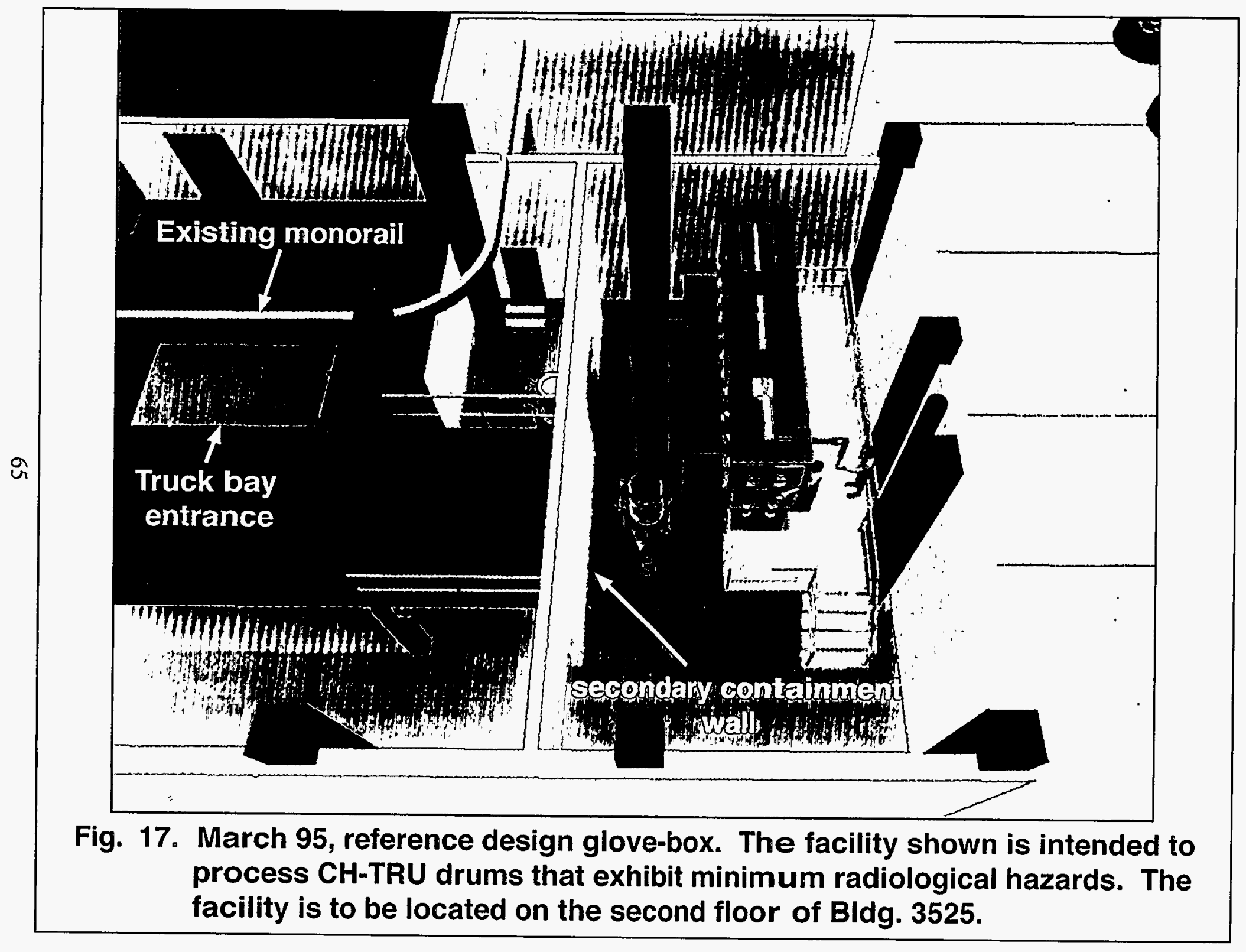




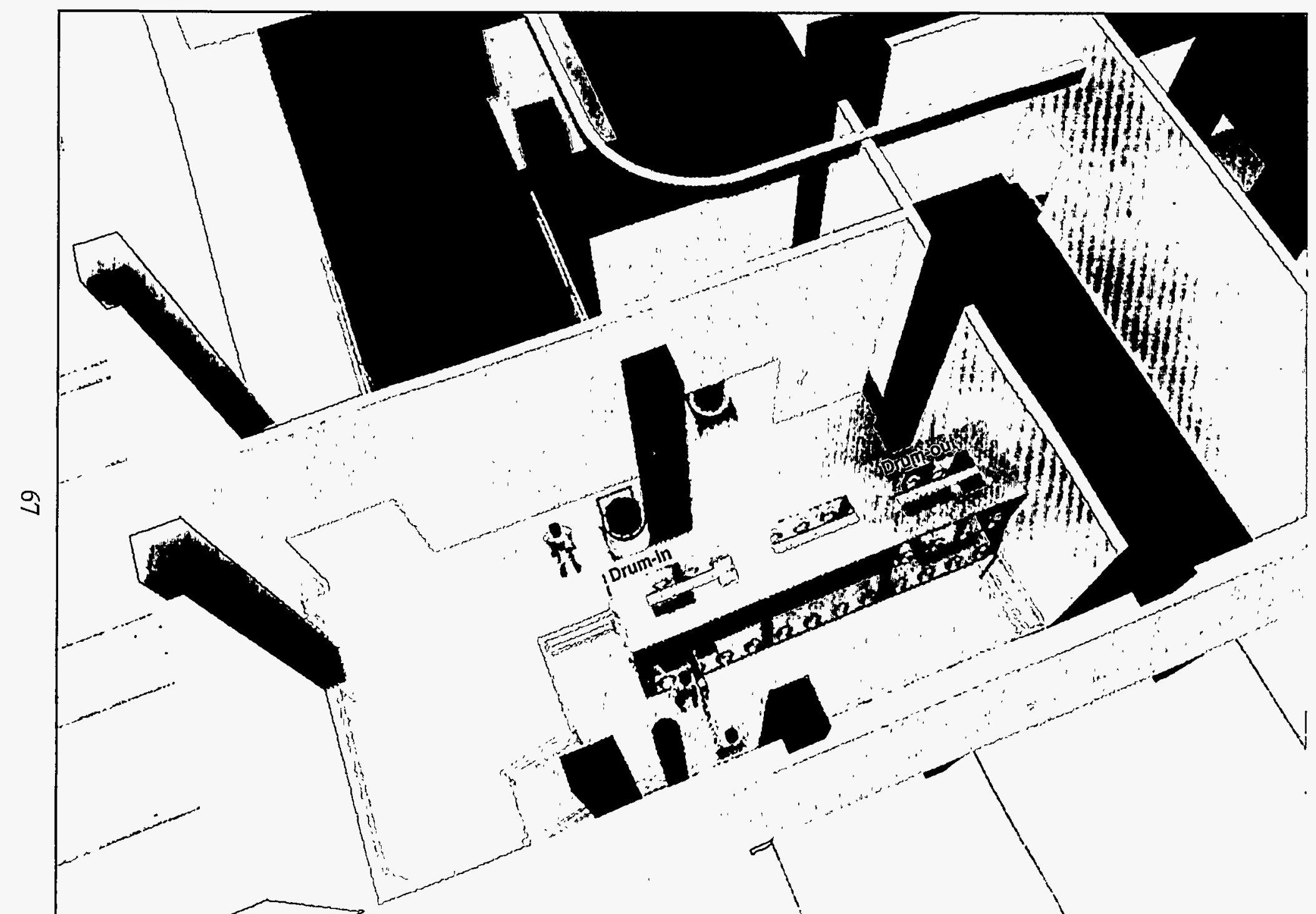

Fig. 18. Makghng5- CH-TRU reference glove-box in minimum risk configuration. Dition $\mathrm{m}$ /drum-out stations are indicated. 



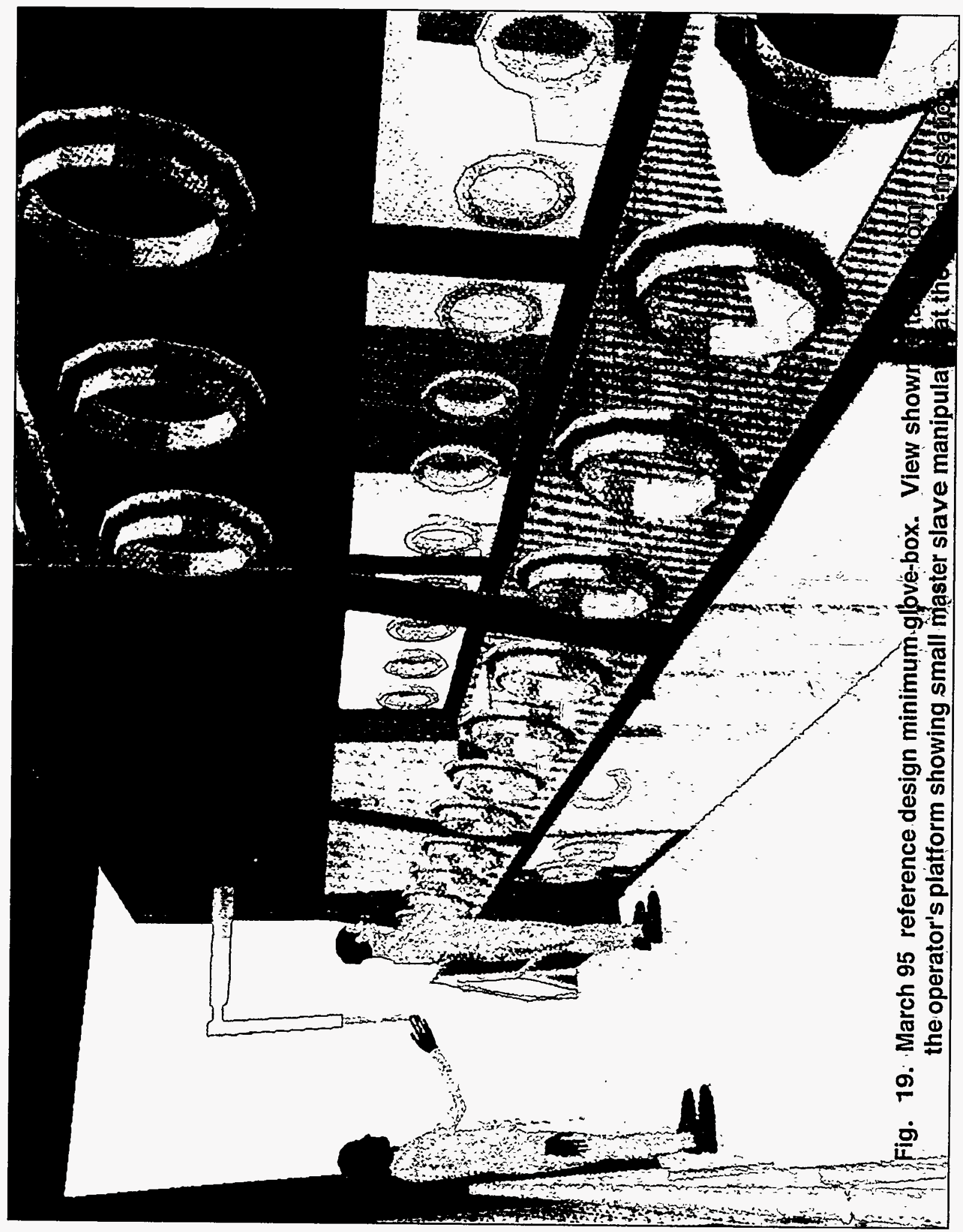





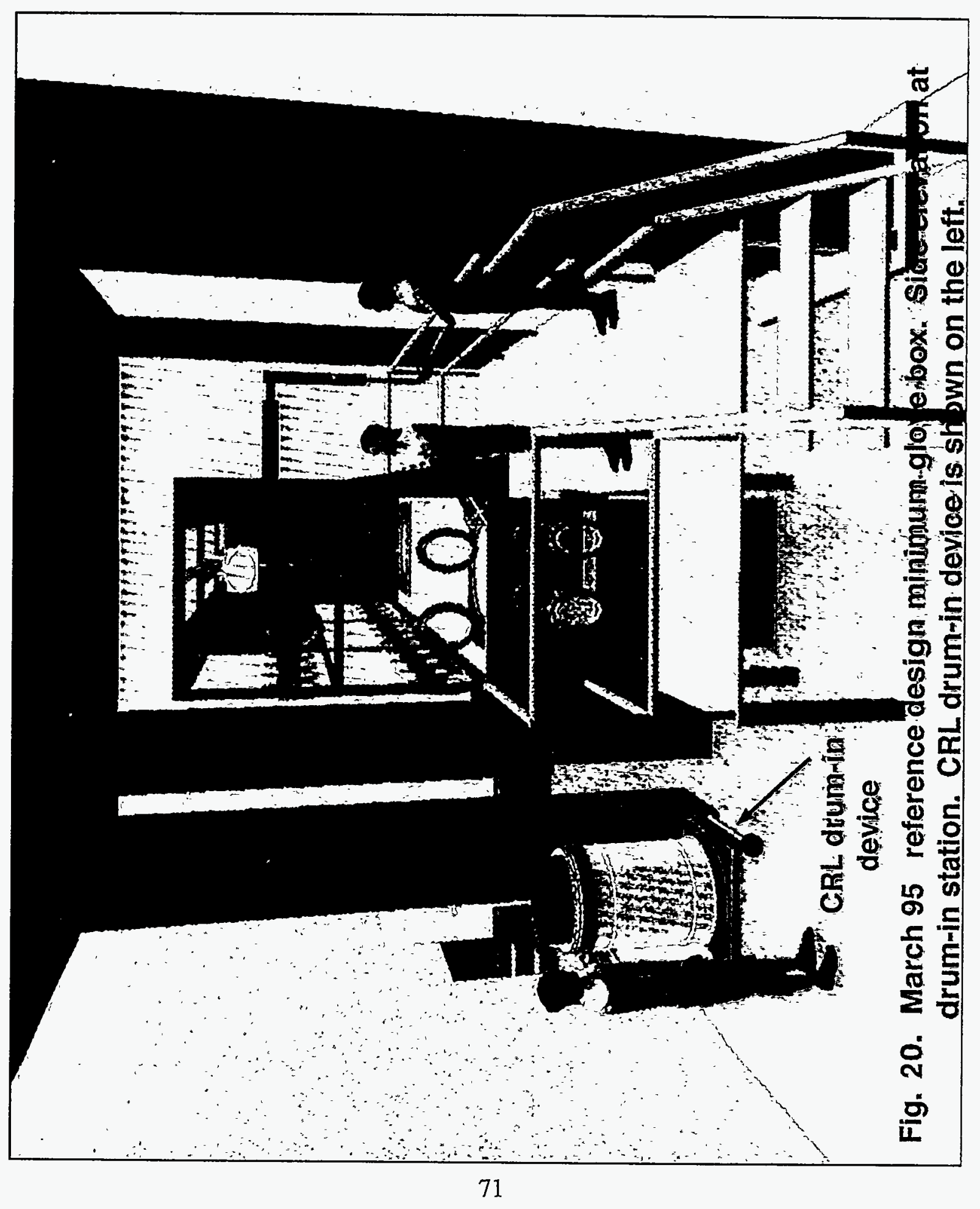



Table 8. Work breakdown structure for the design, fabrication, and installation of the March 1995 reference design basic CH-TRU glove box option to be located on the second floor of Bldg. 3525.

\begin{tabular}{|c|c|c|c|}
\hline WBS & Title & WBS No. & Title \\
\hline $\begin{array}{l}1.00 .95 \\
1.00 .96 \\
1.00 .97 \\
1.3 .1 \\
1.3 .2 \\
1.3 .3 \\
2.0 \\
2.1 \\
2.1 .1 \\
2.1 .2 \\
2.1 .3 \\
2.1 .4 \\
3.0 \\
3.1 \\
3.1 .1 \\
3.1 .2 \\
3.1 .3 \\
3.2 \\
3.2 .1 \\
3.2 .2 \\
3.2 .3 \\
3.2 .4 \\
3.2 .5 \\
3.2 .6 \\
3.3 \\
3.3 .1 \\
3.3 .2 \\
3.4 \\
3.4 \\
3\end{array}$ & 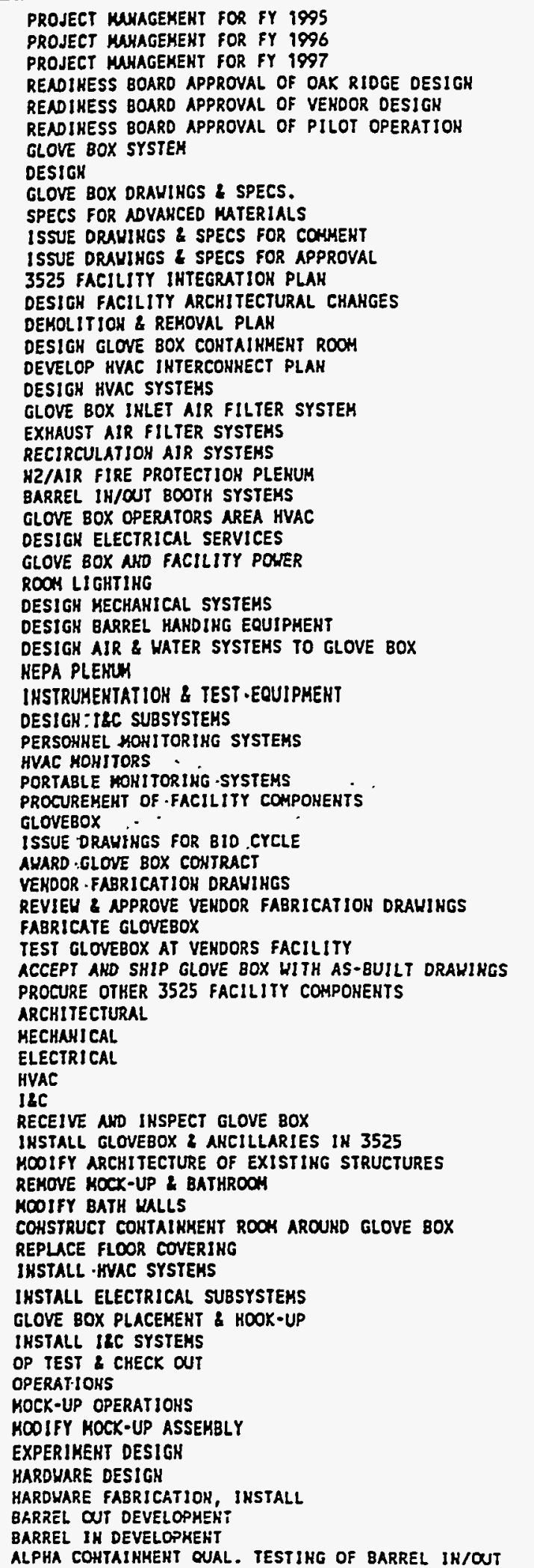 & 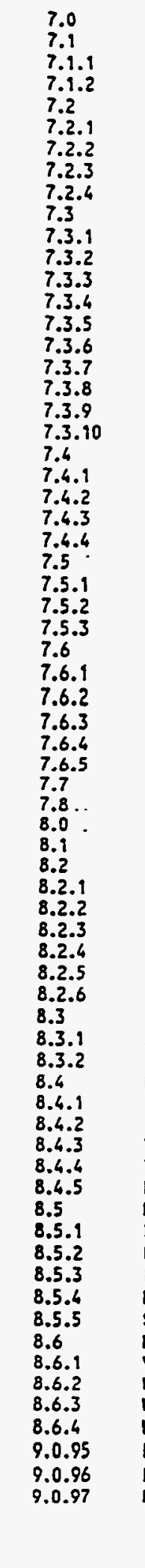 & 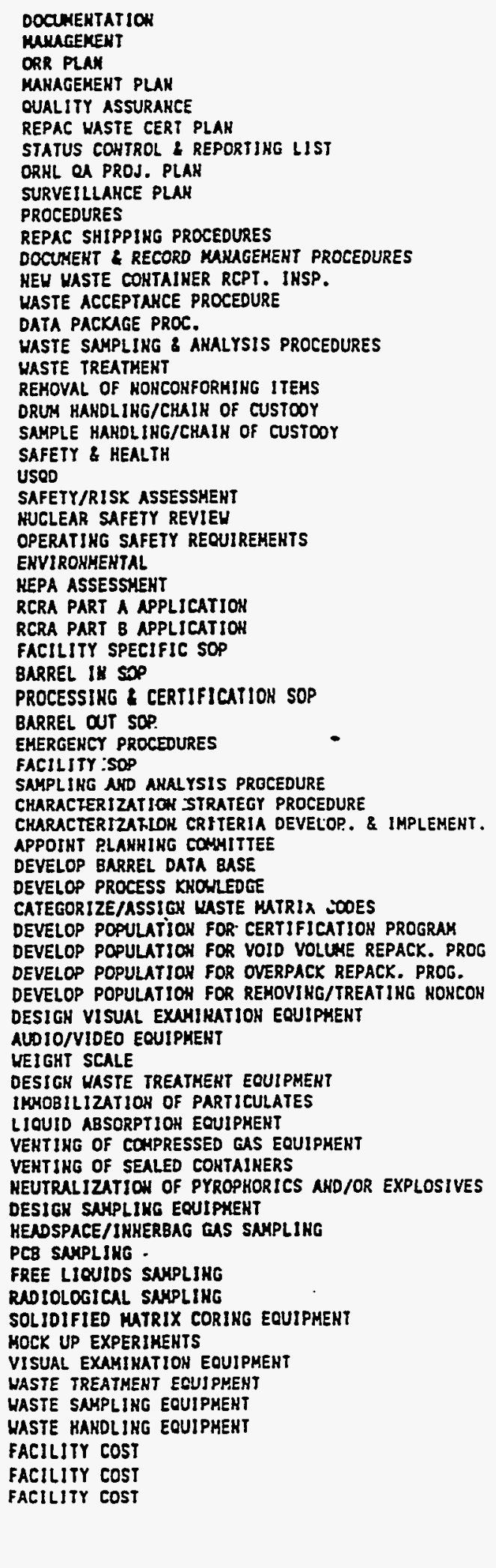 \\
\hline
\end{tabular}


Table 9. Cost estimate for the design, fabrication, and installation of the March 1995 reference design basic CH-TRU glove box option to be located on the second floor of Bldg. 3525 .

\begin{tabular}{|c|l|c|}
\hline \hline WBS No. & \multicolumn{1}{|c|}{ Title } & Cost (\$) \\
\hline 1.0 & Management & 688,000 \\
\hline 2.0 & Glove Box System Design & 219,600 \\
\hline 3.0 & 3525 Facility Integration Design & 237,600 \\
\hline 4.0 & Procurement of Facility Components & 765,600 \\
\hline 5.0 & Install Glove Box and Ancillaries in 3525 & 202,000 \\
\hline 6.0 & Mock-Up Operations and Testing & 190,000 \\
\hline 7.0 & Documentation & 127,000 \\
\hline 8.0 & $\begin{array}{l}\text { Characterization Criteria Development and } \\
\text { Process Testing at Mock-Up Facility }\end{array}$ & 586,000 \\
\hline & Total project & $3,015,800$ \\
\hline
\end{tabular}




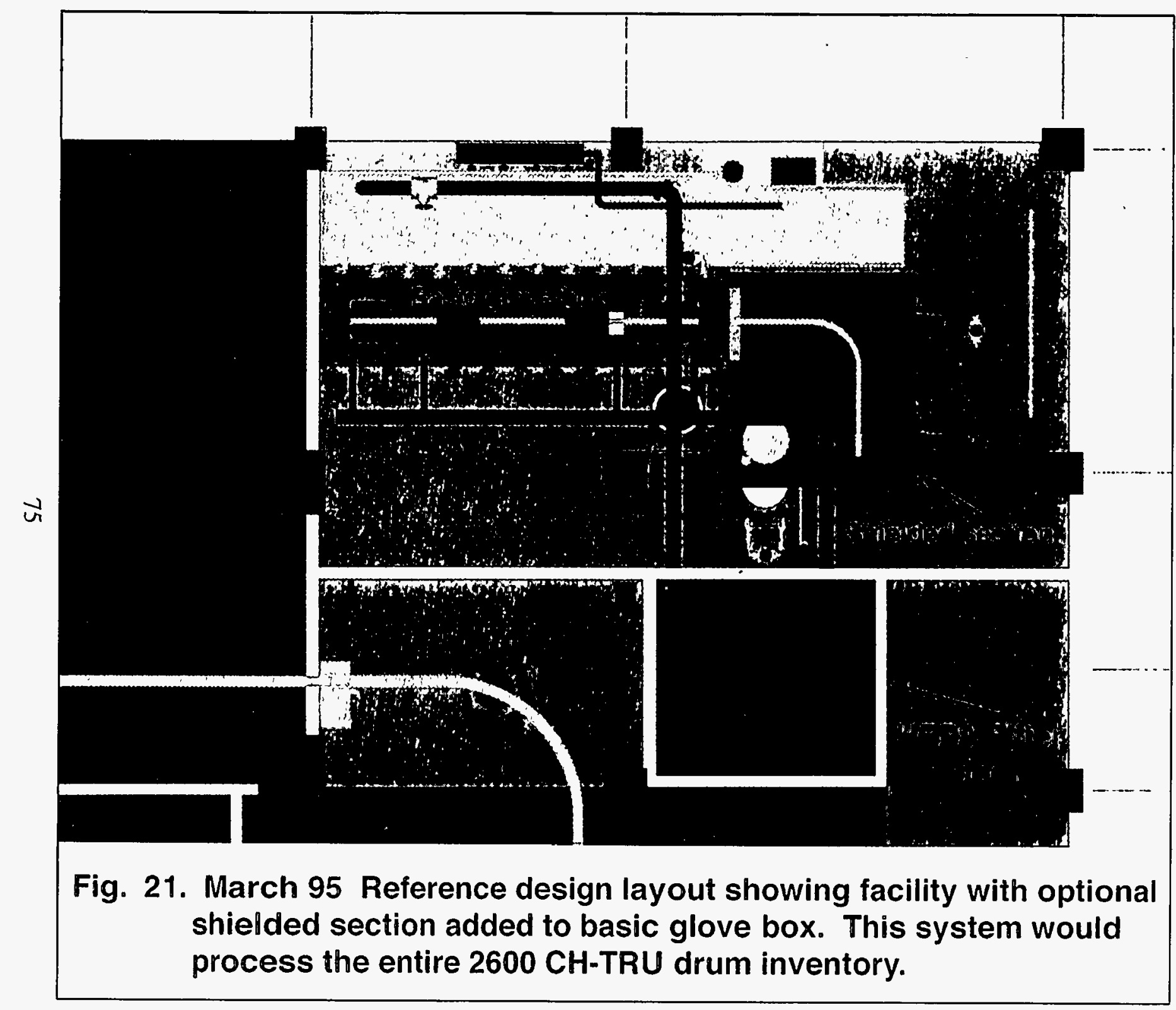





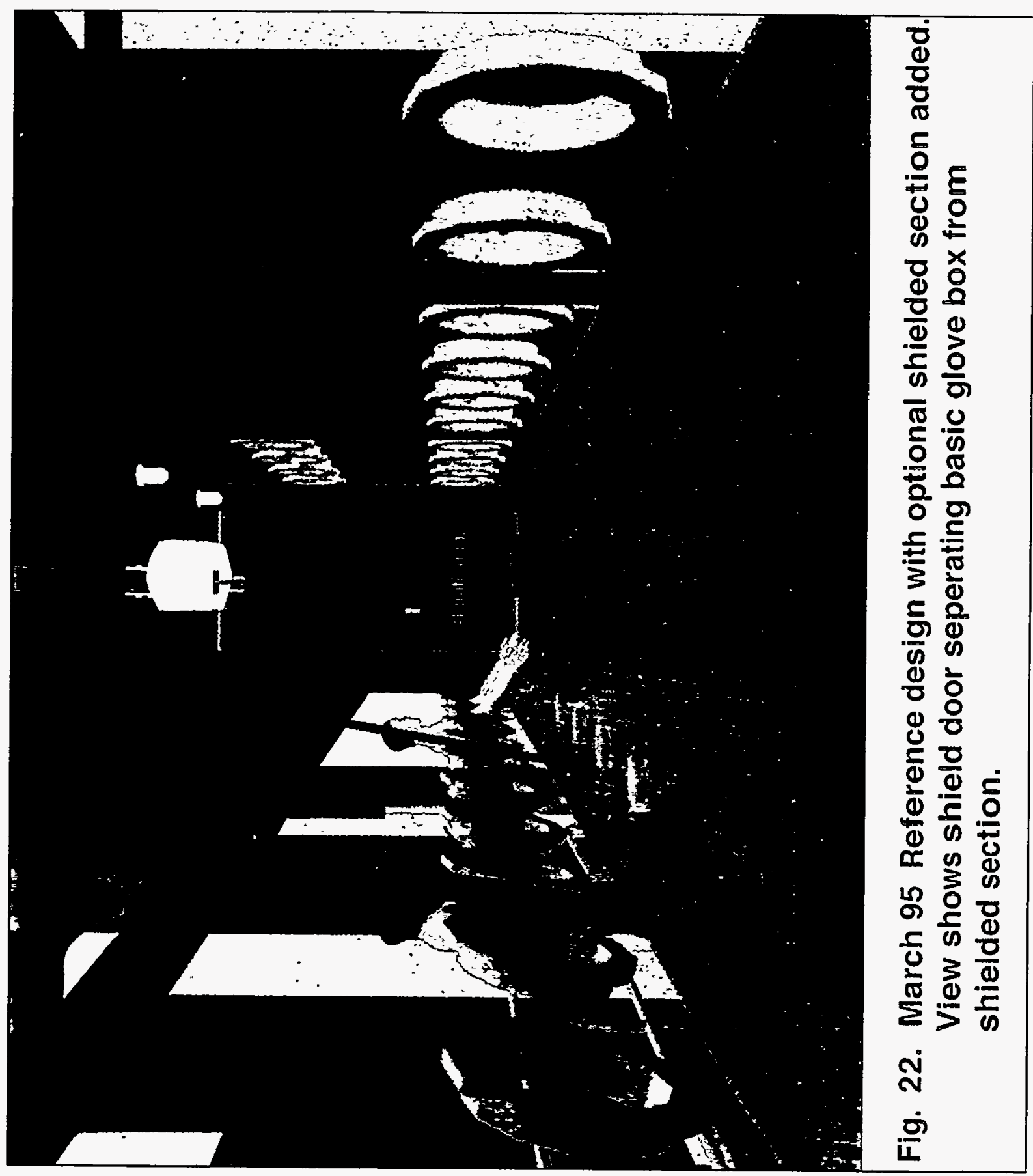





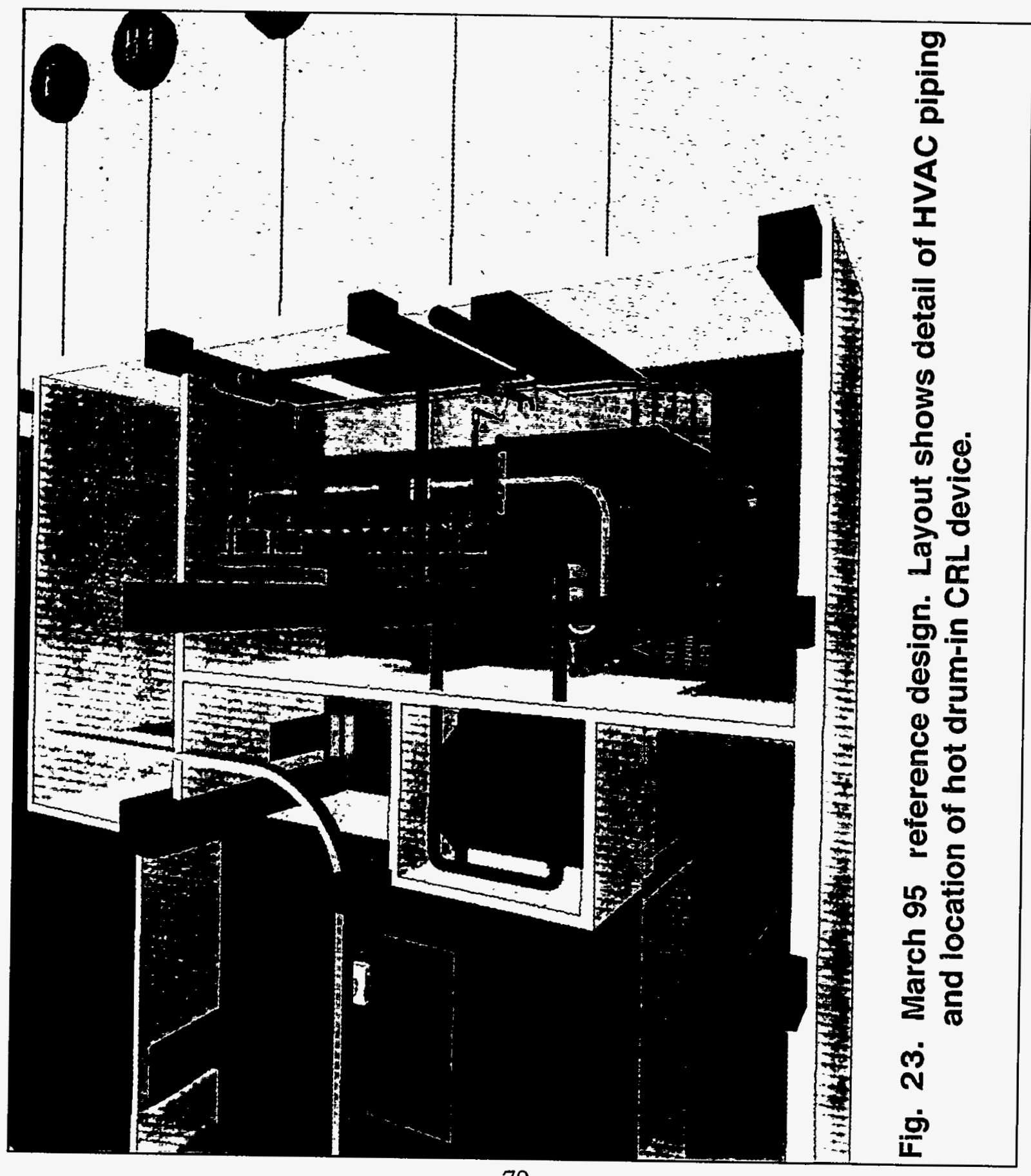

79 



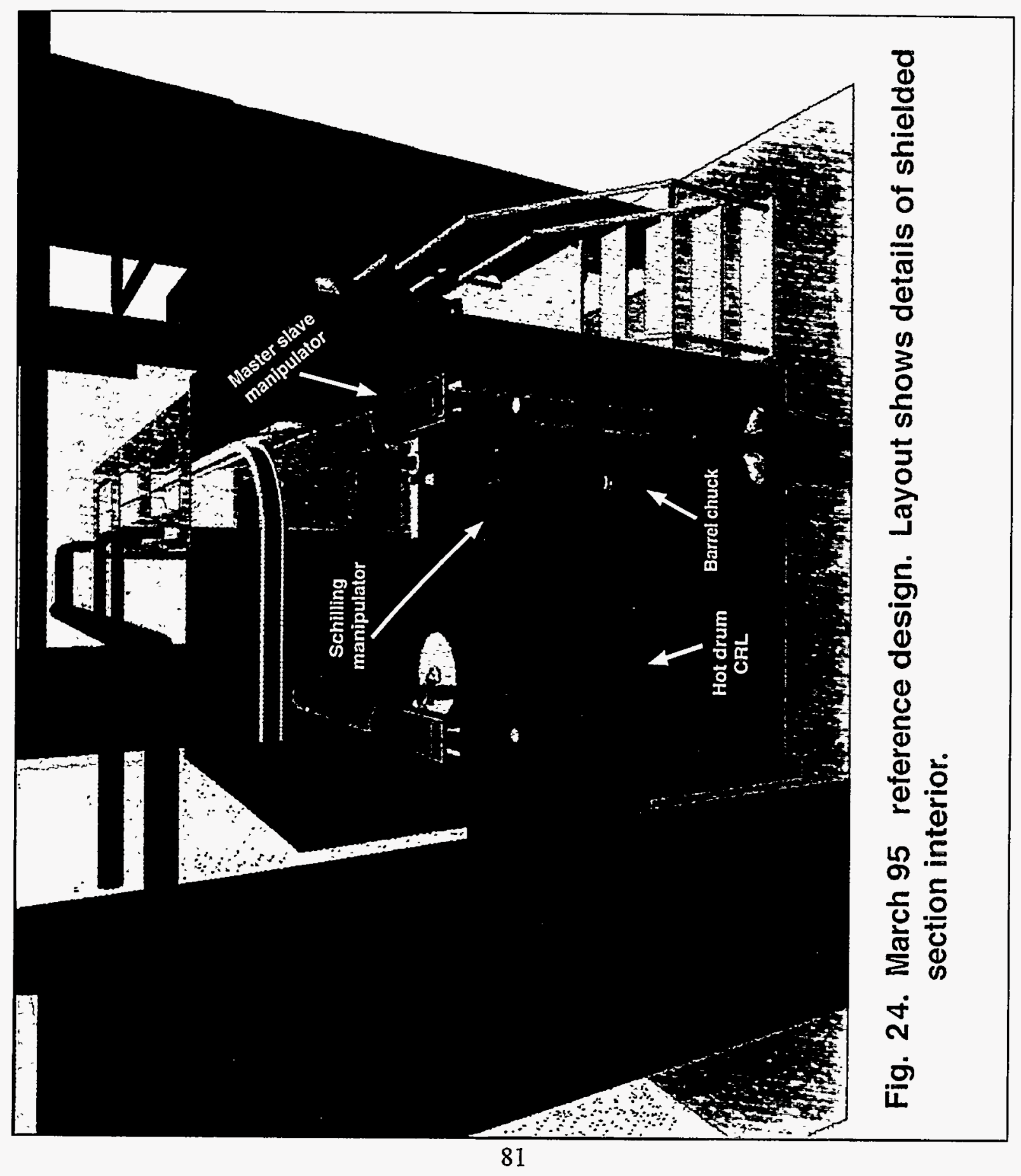



and sent to a hot cell to be disposed of. This design is similar to that described in Section 2, except that it is now provided as an option to the basic glove box.

\subsection{HEATING, VENTLLATION, AND AIR CONDITIONING}

In line with the objectives of reducing cost, the HVAC system for the second floor IFEL facility made use of Building 3525 systems where feasible. Specifically, the exhaust from the new secondary space ties into the existing K-14 filtered exhaust system on the roof. Similarly, the glove box exhaust ties into the $\mathrm{K}-15$ filtered exhaust system that serves existing IFEL hot cells. New local HEPA filtration is provided for so that the glove box exhaust will be HEPA-filtered at two stages and will undergo periodic in-place leak testing. The combined exhaust from the hot cells, the glove maintenance room, and the new glove box ultimately terminates at the 3039 stack. Only when suction from the Building 3039 central stack fails will this exhaust stream issue from the local Building 3525 stack. A schematic of the HVAC system is shown in Fig. 25.

The secondary space, which contains the glove box, is to be separated from other surrounding second-floor areas to further protect the rest of Building 3525. The secondary space, indicated by the wall surrounding the glove box shown in Fig. 23, will be provided with a new filtered exhaust connection and a new make-up air opening. The air source for the secondary glove box containment is the surrounding second-floor space. Each of the two secondary space penetrations is to be provided with counter-weighted back-draft dampers to ensure isolation of the secondary space during K-14 exhaust system downtime. The K-14 system includes a singlefan, HEPA-filtered exhaust system on the building roof. Normal operation of the secondary space is expected to be 0.1 to 0.3 in. $\mathrm{H}_{2} \mathrm{O}$ gage less in pressure than the surrounding second-floor spaces. This more negative pressure condition is intended to correlate with that of the glove box, which would normally be kept 0.4 to 0.6 more negative than the second-floor pressure. These pressure differentials will be continually monitored by high/low pressure alarms.

The temperature in the secondary space will be maintained by a new thin-coil temperature control unit that is arranged with $100 \%$ recirculation and return-air filtration, that is, with 95\%-efficiency isolated filters, to protect the temperature control unit and ducting from any heavy airborne contamination. Anytime the room's constant air monitor detects airborne activity, 


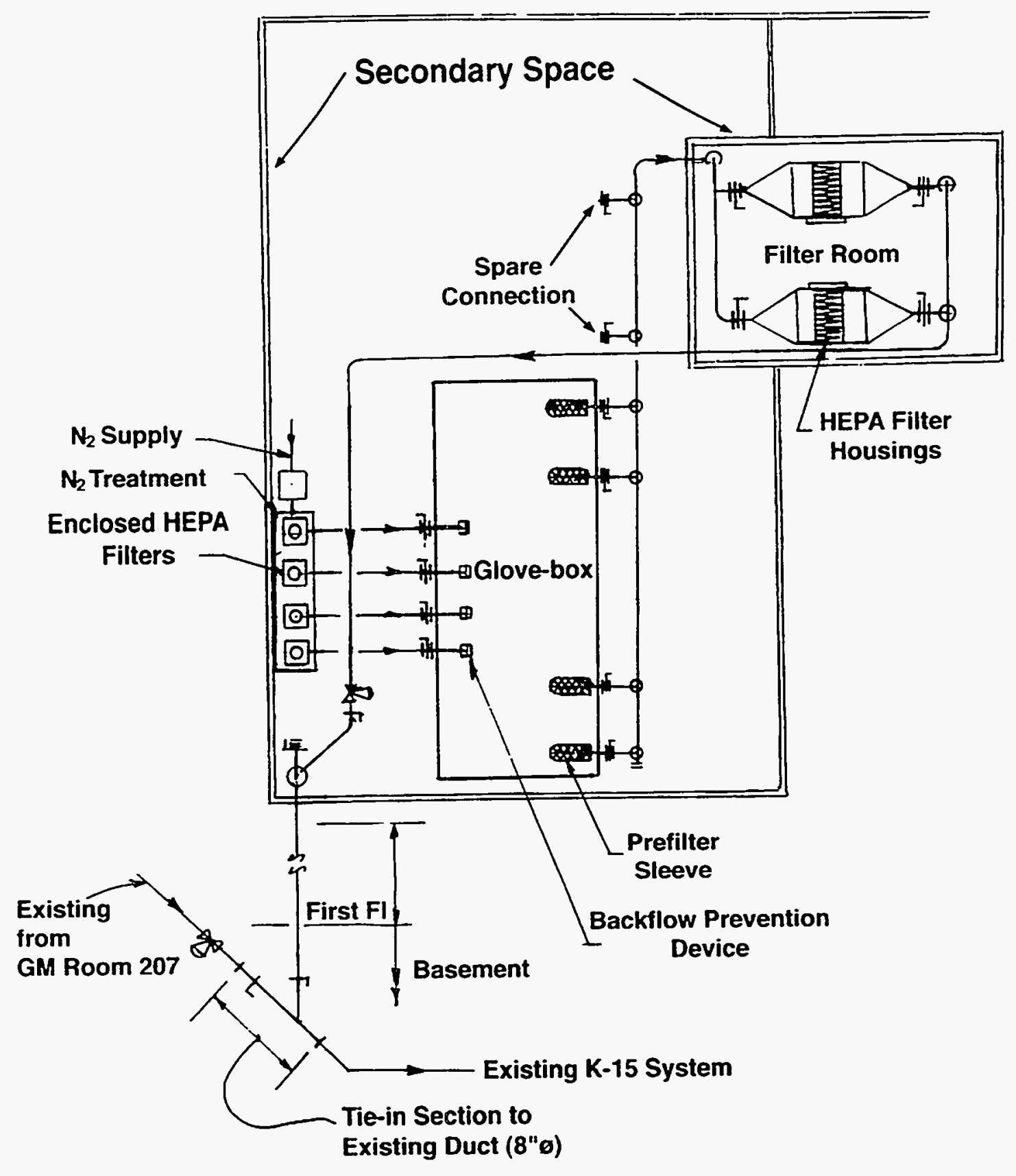

Fig. 25. Schematic of ventilation system for March 95 reference design glove box on second floor of Bldg. 3525. 
airflow in this recirculating system will be automatically stopped. The cooling system uses an existing chilled-water system now serving the second floor in the immediate vicinity of the secondary space. The glove box will be provided with multiple exhaust ports that are connected by a single header (Fig. 25) that goes to the filter, which is ducted to the filter room. In the filter room will be two HEPA-filter housings, the bag-in/bag-out type, to provide for continuous filtration of the glove box exhaust; one housing will be on-line and the other will be in standby status. These HEPA filters will be periodically leak-tested in place. As previously mentioned, the exhaust from these filters will be conveyed to the existing K-15 system serving the cells, where it will be HEPA-filtered again (in the basement) before going to the 3039 stack. Before leaving the glove box, each exhaust port will be prefiltered to minimize transport of larger particulates from the glove box, thereby reducing deposition in the header and downstream ducting. The prefilters will be maintained by glove handling inside the box. The basic glove box arrangement incorporates four exhaust ports, three of which will be operated continuously, while the fourth will be maintained in standby status, ready for emergency use. The inlet ventilation paths to the glove box, currently conceived of as four paths, will be provided HEPA filtration and back-flow prevention. Each of the four equal-capacity paths will function in parallel, with three actively in use and the fourth in standby status to be available for use when any of the other three have scheduled maintenance or for use in an emergency. Currently, we do not intend to leak-test in place the HEPA filters in these inlet paths, unless such testing is mandated. The confusion and added risk of testing intervention are not considered as an advantage to safe glove box operation.

It is intended that an intake nitrogen air mixture be supplied to the glove box by way of the normal inlet ventilation paths to suppress in-box fires. This suppression scheme will limit inbox oxygen concentrations to less than $6 \%$ and will be monitored and maintained continually during periods when combustibles are in the glove box. An existing nitrogen source at the building will be used. The nitrogen will need to be treated locally to raise its temperature above dew-point conditions of the nitrogen air inlet mixture and the prevailing in-box conditions. When low oxygen concentrations are not deemed necessary, the nitrogen supply can be curtailed and all air used as an inlet supply. 
The concept embodied in this description were the basis for the requirements and criteria which were used for this system's cost estimate. In compilation of equipment with quantity estimates, intended installation and routing, and expected restrictions and regulations were all factors considered by the estimator.

\section{MOCK-UP FACLITY}

The primary advantage of constructing a mock-up facility for the $\mathrm{CH}$-TRU process was that it provided the capability to easily and quickly evaluate design concepts, and their ancillary components. A mock-up facility is also a good communication tool between design and operating personnel. This interaction is extremely important for many technical, safety, and operational reasons.

In a mock-up facility, there is the opportunity to test and evaluate auxiliary equipment that may be of some special nature. In our case, for example, we have tested the drum bag-in/bag-out system and, through interactions with the manufacturer, both parties have received helpful feedback. We have been able to easily modify this system and accommodate the design changes. Other advantages include the opportunity to use the mock-up facility as a training tool for developing operational procedures. This capability helps to eliminate uncertainties in glove box design and in the waste characterization. Other advantages include the avoidance of costly errors and quality failures and reduced design and training time.

\subsection{DESIGN FEATURES}

Fig. 26 shows the primary structural element designed for the glove box mock-up. A series of these wooden frames were made from hard maple to use in the mock-up and were designed to be adjustable so that the depth of the glove box could be varied. They can be attached to wooden tables of varying length, providing the capability to simulate a variety of practical glove box configurations. The top of the mock-up was left open so that side-wall panels of varying height could be added to simulate different glove box side wall configurations. With 


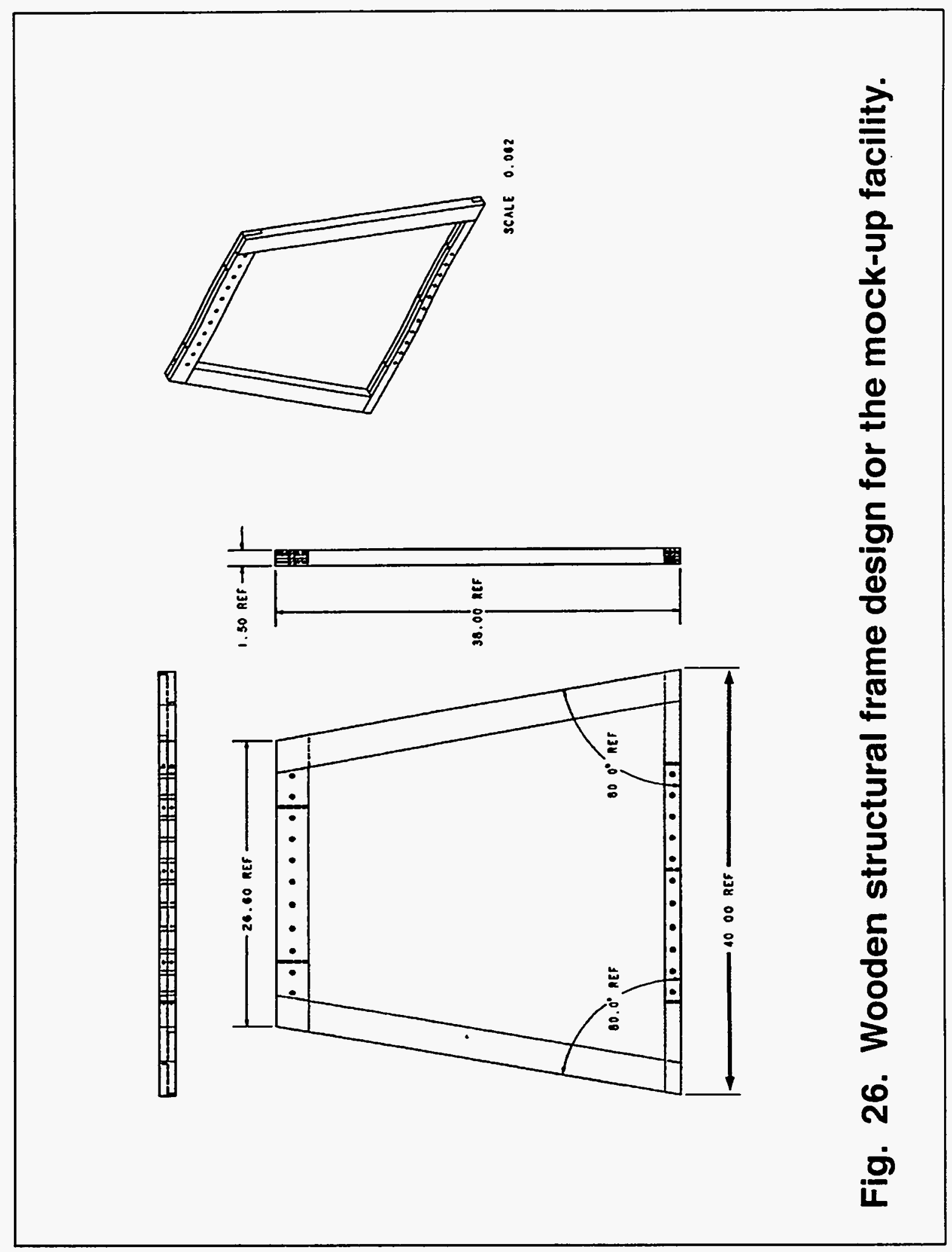


this design, different assemblies and arrangements of the configuration could be easily modified by using ordinary carpentry tools.

Fig. 27 shows the mock-up facility in the original configuration for simulating the reference design in the basement of Building 3525 . This configuration could be changed to match the new layout described in Section 5 within two weeks. Also shown in the figure are the drum-in system and the drum-out system; these prototype units have been extensively tested and will be discussed later in this section. The figure also shows the master-slave manipulator borrowed from REDC to evaluate various aspects of loading and unloading the drums. The internal work space in the glove box is about $140 \mathrm{ft}^{2}$ and was used to begin addressing processing questions such as "What equipment does it take to characterize this material?"

\subsection{OPERATION}

The primary purposes of the mock-up facility used in this program are to

1. test auxilliary equipment in a realistic glove box environment,

2. identify design and operational problems and provide cost-effective test methods for solving these problems, and

3. train operating personnel and develop procedures.

Following construction of the facility in December 1994, IFEL supervisors, operators, and HP staff were briefed on the series of tasks that we knew would be required of the actual $\mathrm{CH}-\mathrm{TRU}$ facility. In this context, they were asked to suggest activities that they thought were important to accomplish with this mock-up facility. Their suggestions included testing methods to unpack, visually examine, process, and repack 55 -gal drums of transuranic waste. Other suggestions emphasized that one of their principal concerns was to contain the extremely highactivity alpha radioactivity and maintain worker beta/gamma radiation exposure within ORNL ALARA limits. They suggested that simulation activities be set up to answer two questions: (1) What features do we have in a glove box for handling drums with an external dose of up to $10.5 \mathrm{mrem} / \mathrm{h}$ and (2) What will we need to ensure fail-safe alpha containment? 


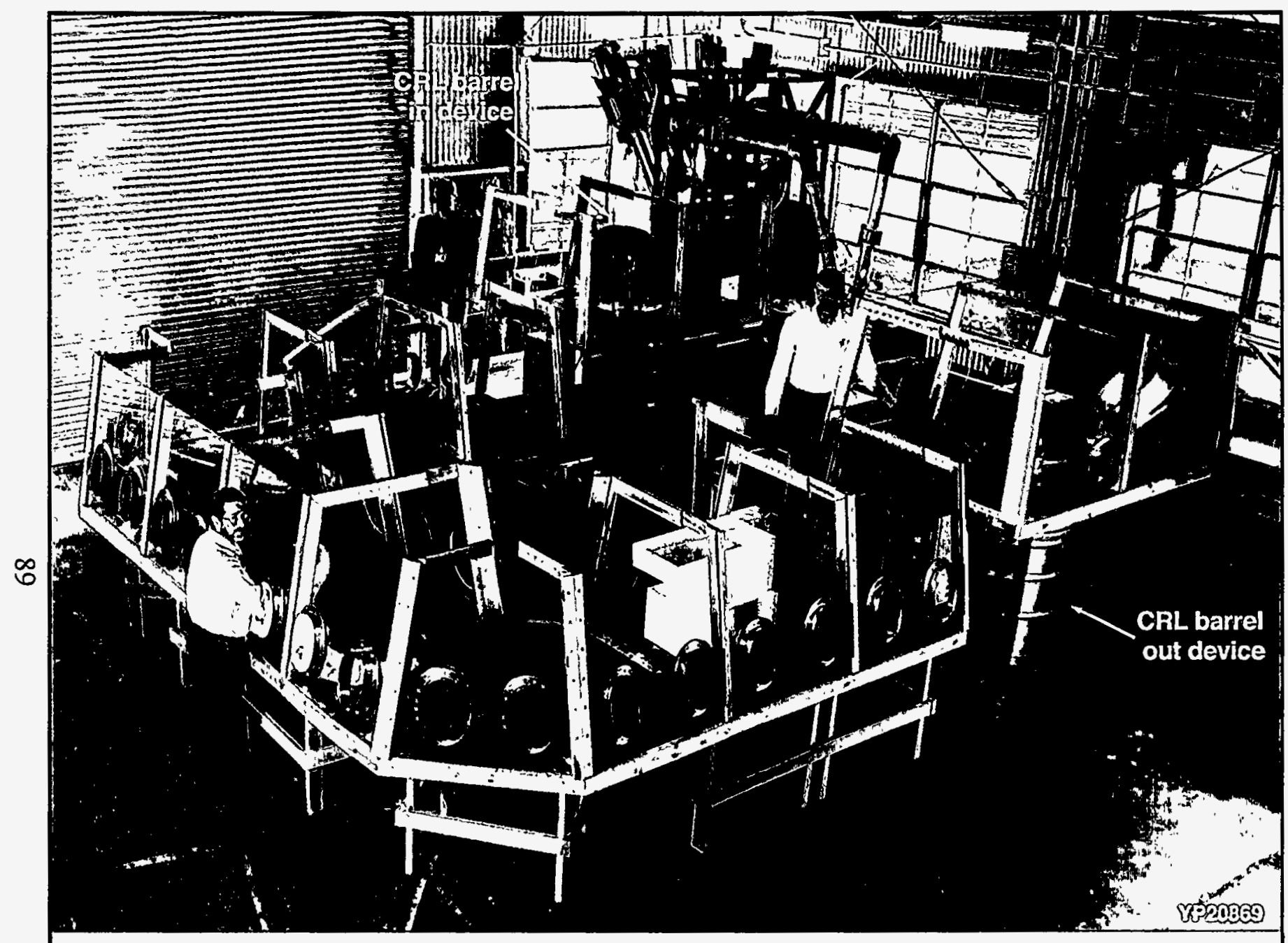

Fig. 27. CH-TRU drum characterization mock up in Bldg. 3012. Mock up is in the October 94 reference design configuration. 



\subsubsection{Drum-In/Drum-Out Testing}

To answer these questions, we began by testing the drum bag-in/bag-out units because they are the weakest link of the alpha-containment system. For many reasons, whenever a drum comes in or goes out of a less than perfect system, these operations are judged to be the most vulnerable with respect to alpha containment. Because this operation will be done routinely, it will have the greatest opportunity to lose containment.

Fig. 28 shows the drum-in unit, which consists of a lift cart, a glove-box drum port, and battery-powered drum lifts. The photographs in Figs. 29 and 30 shows this assembly mounted in the glove-box mock-up. Fig. 30 shows the 55-gal drum as it would appear on the glove-box interior.

\subsubsection{CRL Drum-in Configuration}

The drum-in device allows the entrance or exit of a 55-gal drum into an enclosure without breaking the containment barrier. The equipment tested consists of an 85-gal drum that is fitted with a drum-lifting device within the bottom of the 85 -gal drum such that a 55 -gal drum that has been place inside can be raised up to where it can be easily pulled from the 85-gal drum using a lifting fixture attaced to an overhead hoist. The containment of this operation is provided by a plastic bag that becomes part of the barrier as the 85-gal drum is docked to the enclosure. The plastic bag lines the 85 -gal drum and the 55-gal drum is placed within this bag before docking to the enclosure.

\subsubsection{CRL Drum-In Procudure}

1. A sealed 55-gal drum that is ready to be processed is lifted up by a hoist and a lifting fixture is attached to the top of the remaining drum.

2. A plastic bag is secured to a polyethylene support ring by means of two O-rings (Fig. 31).

3. The support ring/plastic bag assembly is then slipped around the elevated drum from the bottom and pulled up so that the bag bottom is against the drum bottom. The support ring is then rotated to twist the excess bag material at the top and therefore hold the support ring up at the top of the drum. 


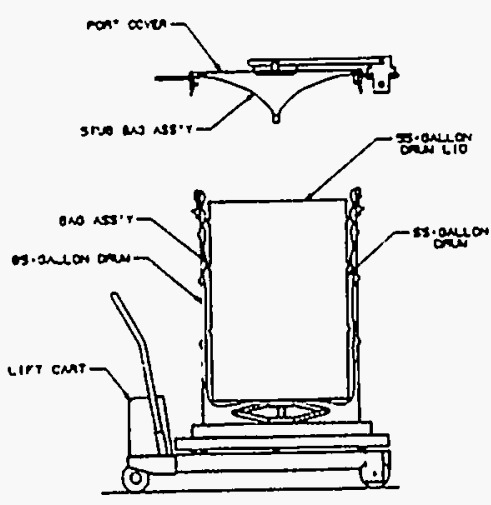

STEP ।

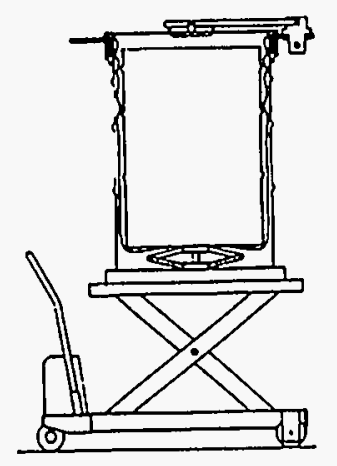

STEP 4

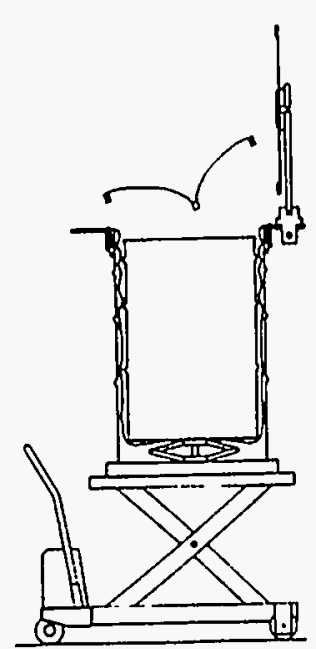

S.EP 2

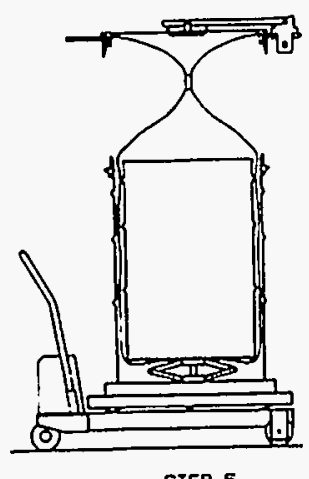

STEP 5

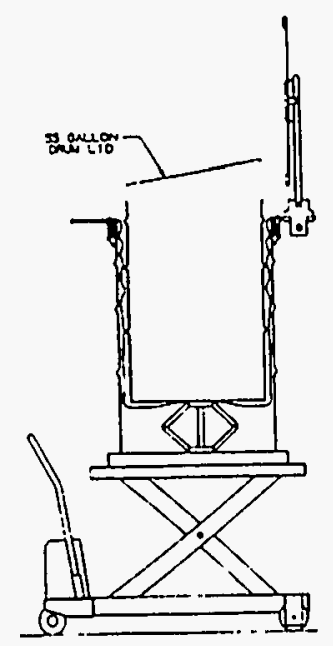

STEP 3

Step 1: Load a 55-gallon drum Into transfer drum

Step 2: Open port, elevate and Insert bag assembly In port.

Step 3: Elevate 55.gallon drum and remove lid.

Step 4: Relnstall drum lid, lower 55-gallon drum and close port.

Step 5: Lower transter drum and bag out 55-gallon drum.

\section{Fig. 28. CRL drum-in device operating procedures.}




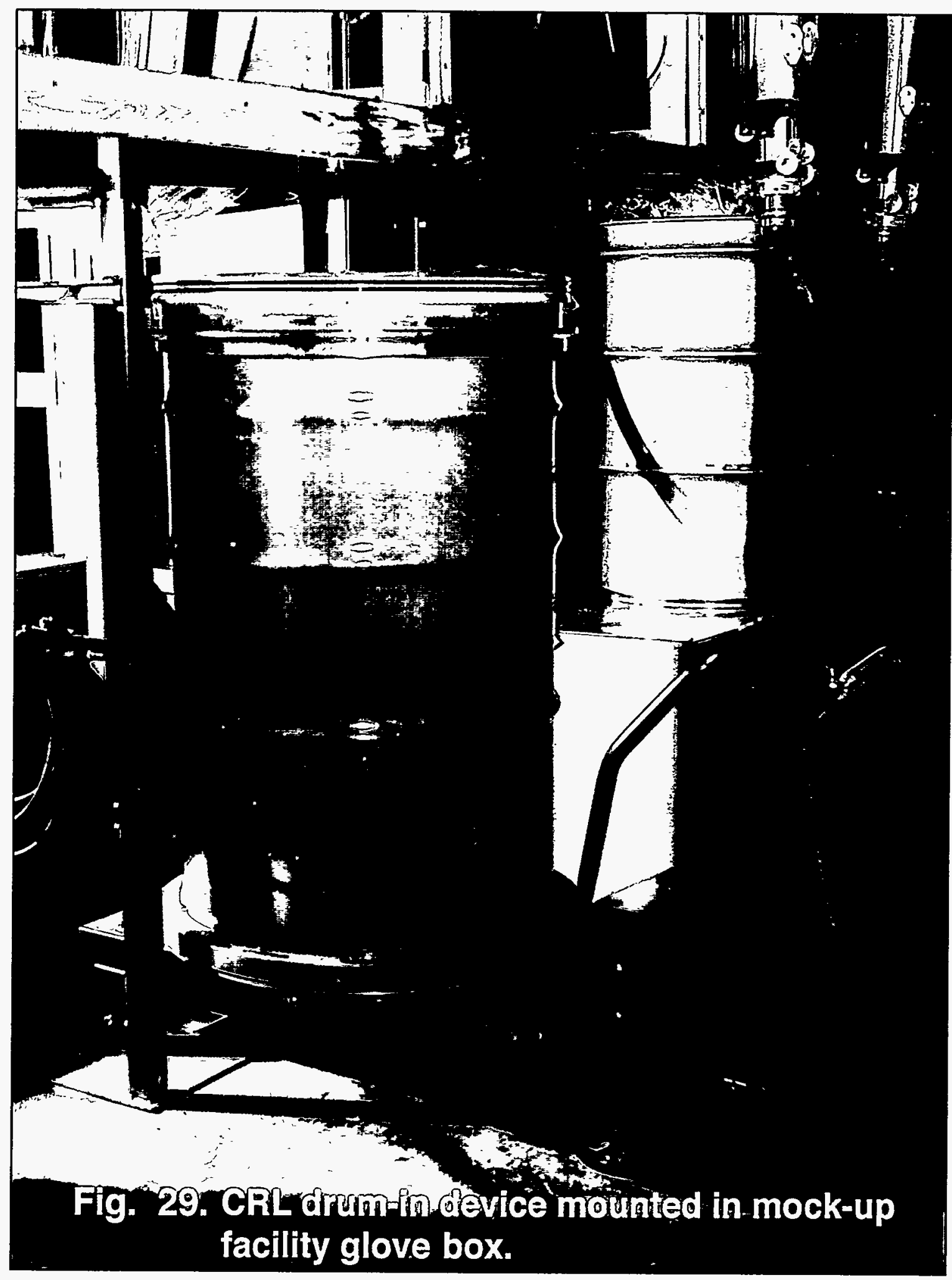



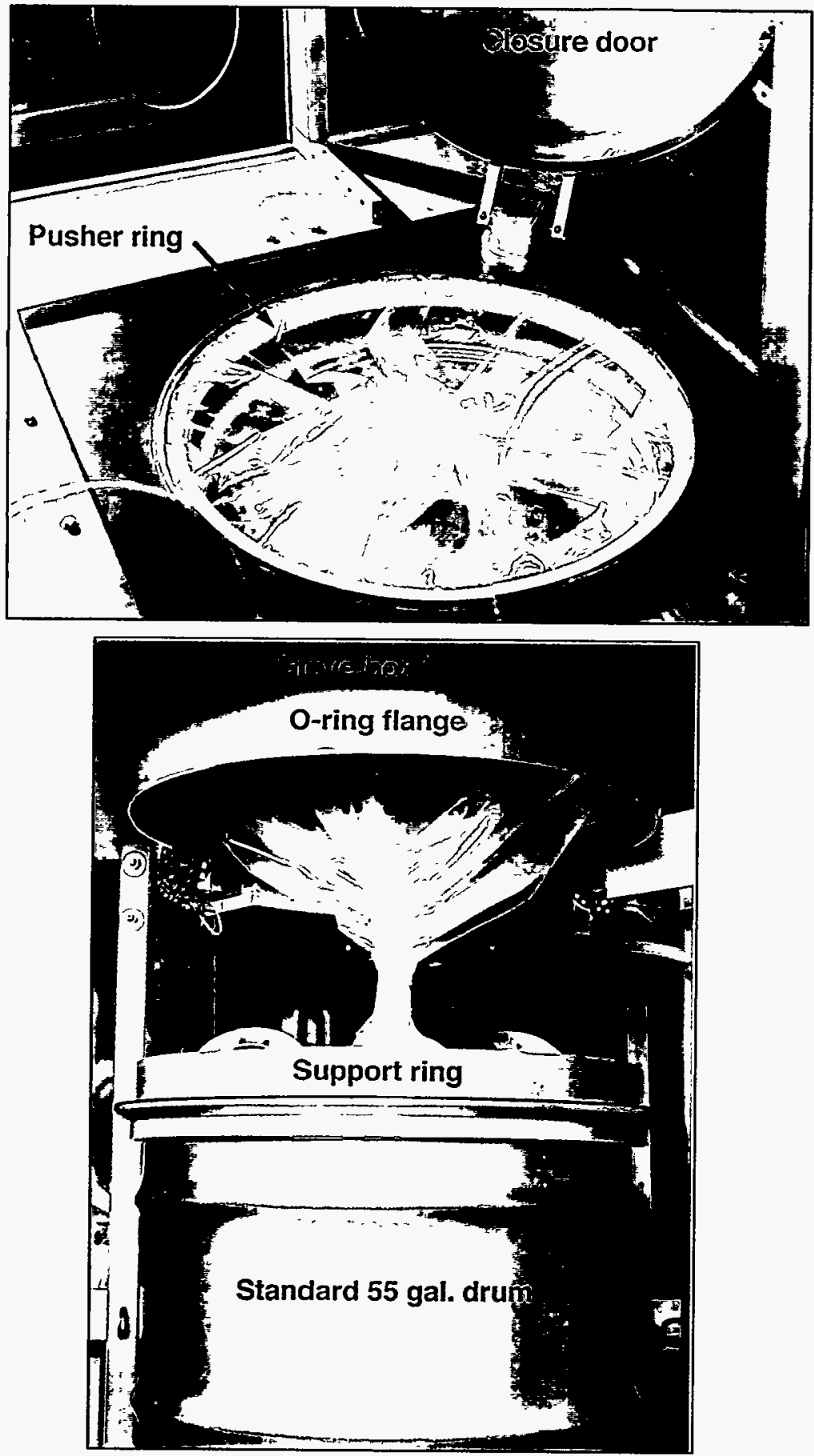

Fig. 30. CRL drum out device mounted in mock-up facility 



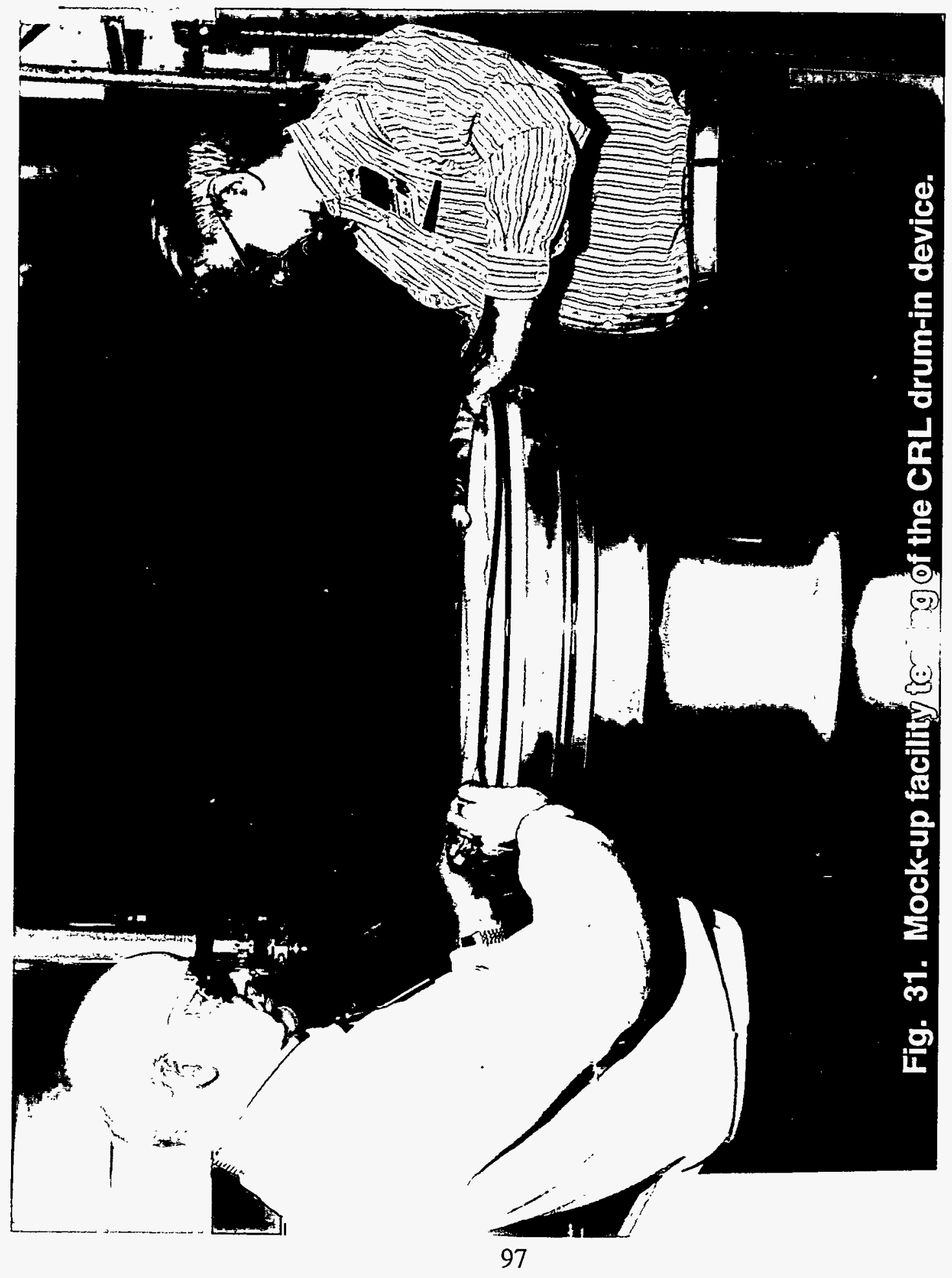




\section{-}


4. The 55-gal drum with the bag around it is then lowered into a special 85-gal drum that has been mounted on a lifting cart. This 85 -gal drum has an intenal lift mechanism that will raise the 55-gal drum, which has been placed inside, approximately 12 in. once the 85 -gal drum has been docked to the enclosure. (Fig. 28, Step 1).

5. The support ring is rotated in the opposite direction to eliminate the twist placed in the bag previously. The lifting fixture is disconnected from the drum and the hoist and fixture are removed out of the way. The excess bag material is carefully pushed down into the annulus between the 55-gal drum and the 85-gal drum (Fig. 32).

6. A swaging collar is placed on top of the drum with the gasketed surface up. A light lubrication using vacuum grease, is placed on the O-rings.

7. The dolly is rolled underneath the enclosure and positioned under the guide ring on the bottom of the glove-box (Fig. 28).

8. The 85 -gal drum is lifted by the dolly to a position approximately $1 / 2$ in. below the lower edge of the guide ring and final alignment is made to center the swaging collar on top of the drum in the guide ring on the bottom of the enclosure.

9. The dolly is locked in place to prevent shifting.

10. The lid inside the enclosure that covers the docking port is raised. Note that the hole is sealed by a bag stub left over from a previous bag-out (Fig. 28).

11. The 85-gal drum is lifted by the dolly so that the swaging collar docks to the guide ring.

12. The dolly is raised until the support ring seats within the guide ring and the support ring/bag stub from the previous bag-out is ejected into the enclosure. This old support ring is then cut to allow it to be processed as waste (Fig. 28, Step 2).

13. The lifting mechanism that is within the 85 -gal drum is used to lift the 55 -gal drum up into the enclosure approximately $12 \mathrm{in}$.

14. The 55-gal drum lid is removed by whatever means is available inside the enclosure.

15. The waste inside the drum is removed one item at a time.

16. The 55-gal drum is either lifted out of the 85 -gal drum and bag and processed, is left in place while being emptied, or is lifted out and emptied and returned to the bag. 



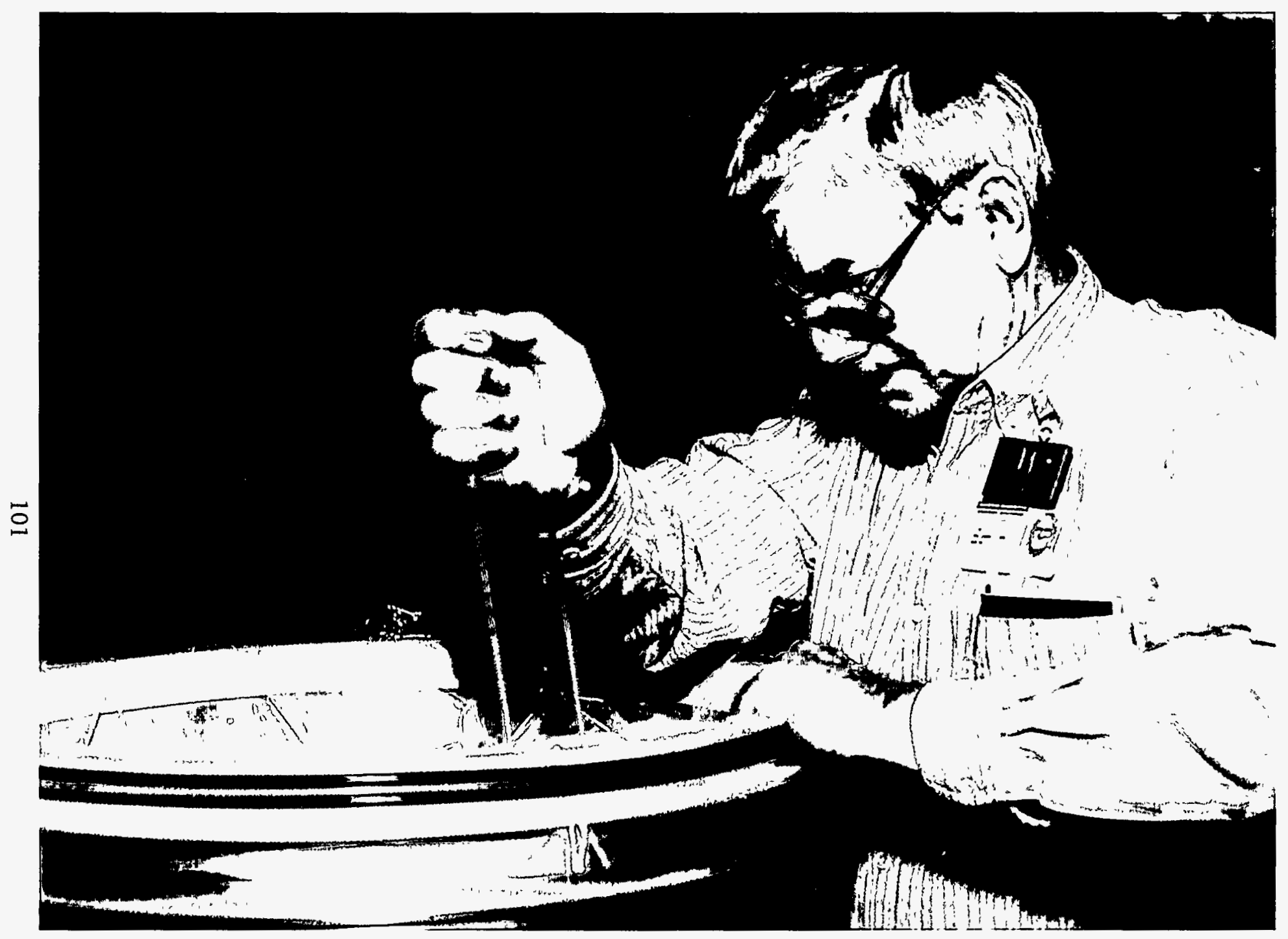

Fig. 32. Testing of the mock-up facility of the CRL drum-in device. Pushing the excess bag material into the annulus between to 85 -gall 55 -gall drums. 



\subsubsection{Removal of Empty 55-Gal Drum}

1. Lower the 55-gal drum by means of the lifting device included in the 85-gal drum.

2. Close the lid inside the enclosure (Fig. 28, Step 4).

3. Lower the dolly slowly, allowing the excess bag material to deploy (Fig. 28, Step 5).

4. Once the dolly is lowered all the way, rotate the drum to twist the bag closed until a tight column of bag material is achieved.

5. Tape this column tightly over a 3-in. length (Fig. 33).

6. Use a PVC pipe cutter or razor knife to cut the 3-in. band of tape in the middle so that $1 \frac{1}{2}$ in. of tape remains on each side of the cut (Fig. 34).

7. Cover the cut ends with tape to contain contamination.

8. Roll out dolly.

9. Place lid on 55-gal drum.

10. Remove from 85 -gal drum.

\subsubsection{Drum-Out Test}

The drum-out unit (Fig. 35) is very similar to the drum-in unit; the difference is that a new 55-gal drum is being filled with material after it has been processed, which eliminates the need for an overpack configuration (as described for the drum-in unit). The particular unit tested was provided with a prototype automated system that was found to operate poorly. The vendor will probably try to develop an improved system based on our testing. This feature would physically remove the operators from the drum-in/drum-out process.

\subsection{RESULTS}

Initial testing demonstrated the usefulness of the mock-up facility. The initial drum-in/drum-out activities provided many suggestions for design improvements that were given to the developer of these units. All of these suggestions would result in only minor design changes and, as a result, the CRL devices remain our reference concept for continuing development. 



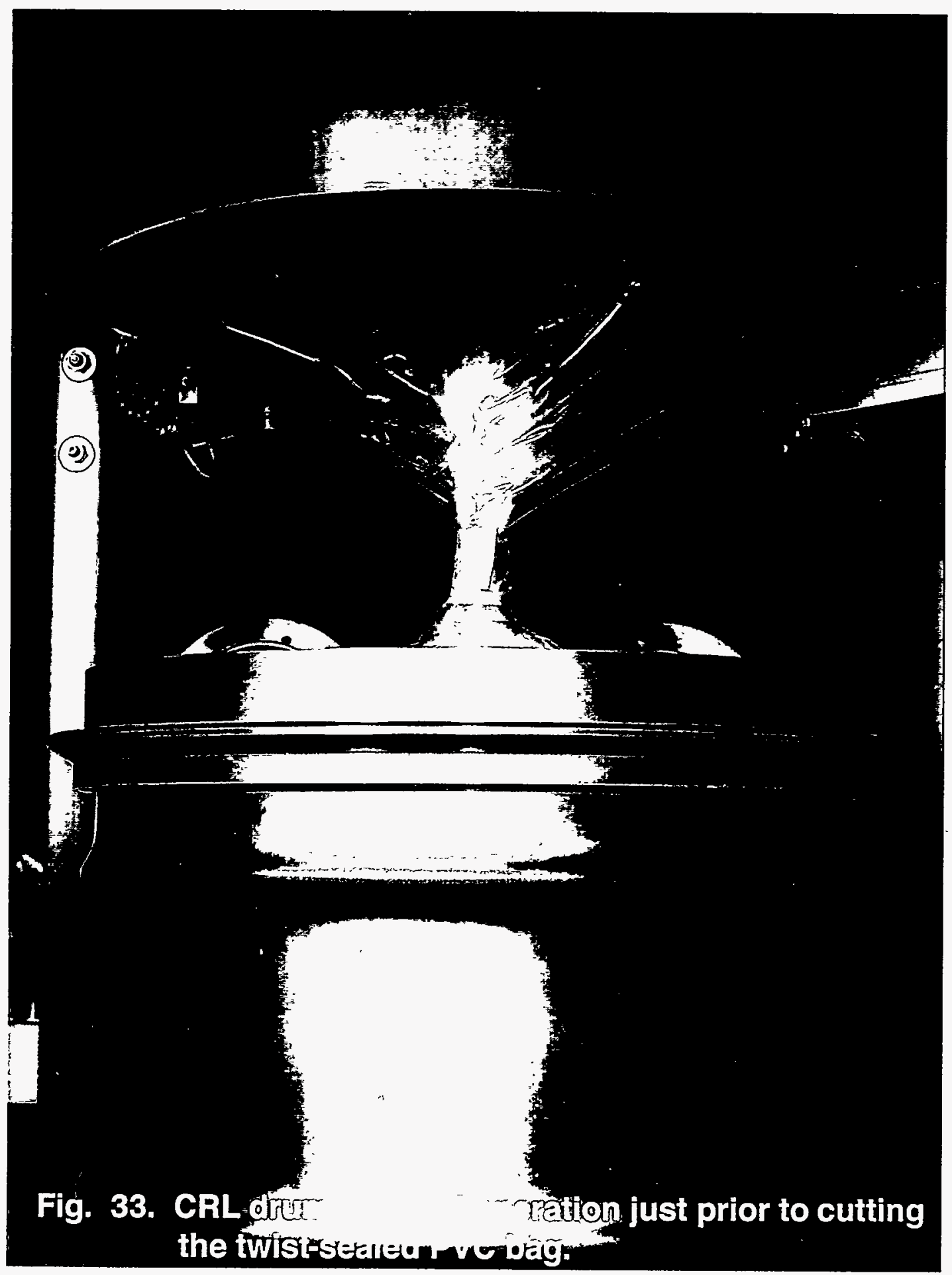




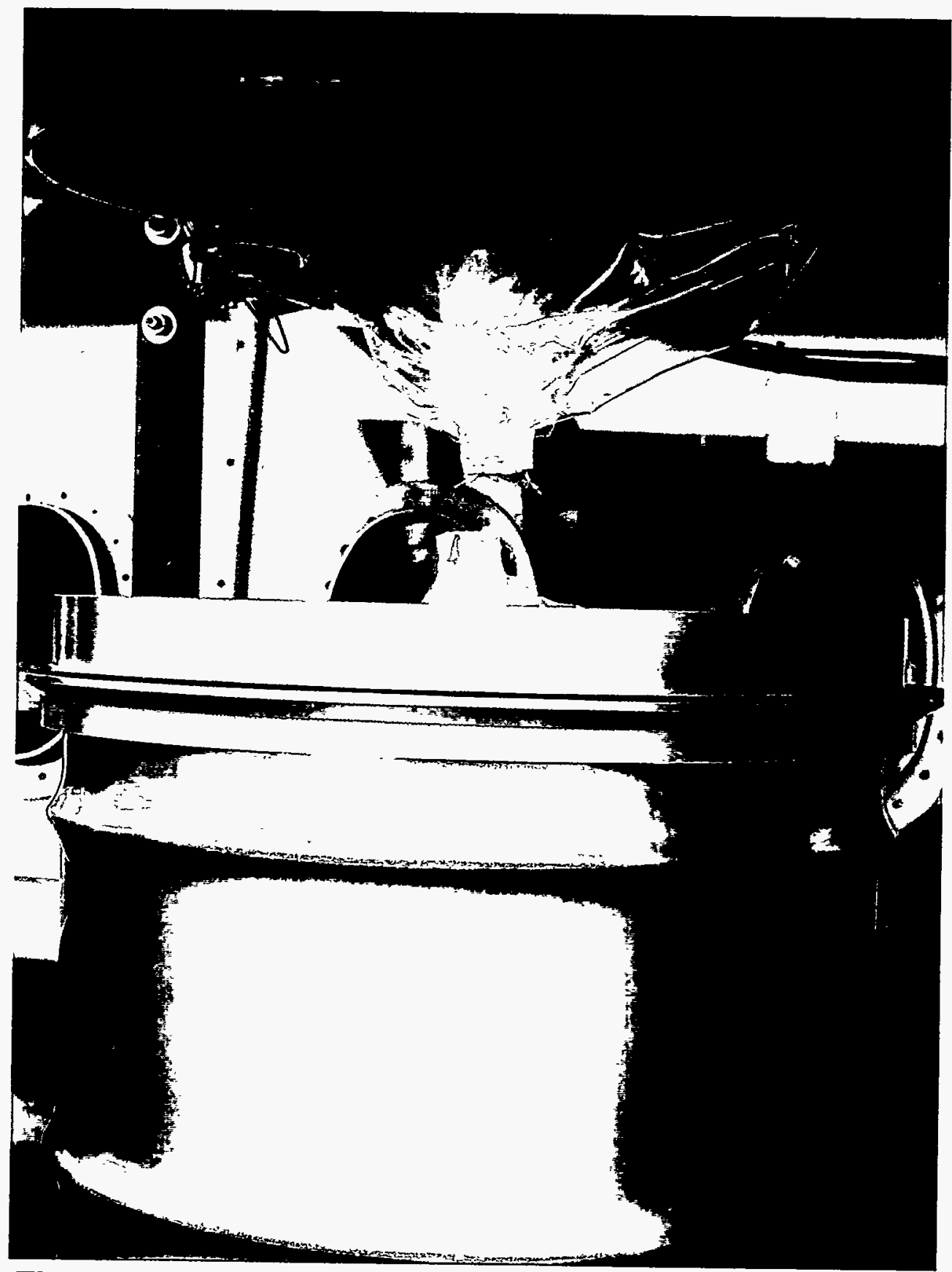

Fig. 34. Drum interior bag after seperation from the glove box just prior to placement of the drum lid. 


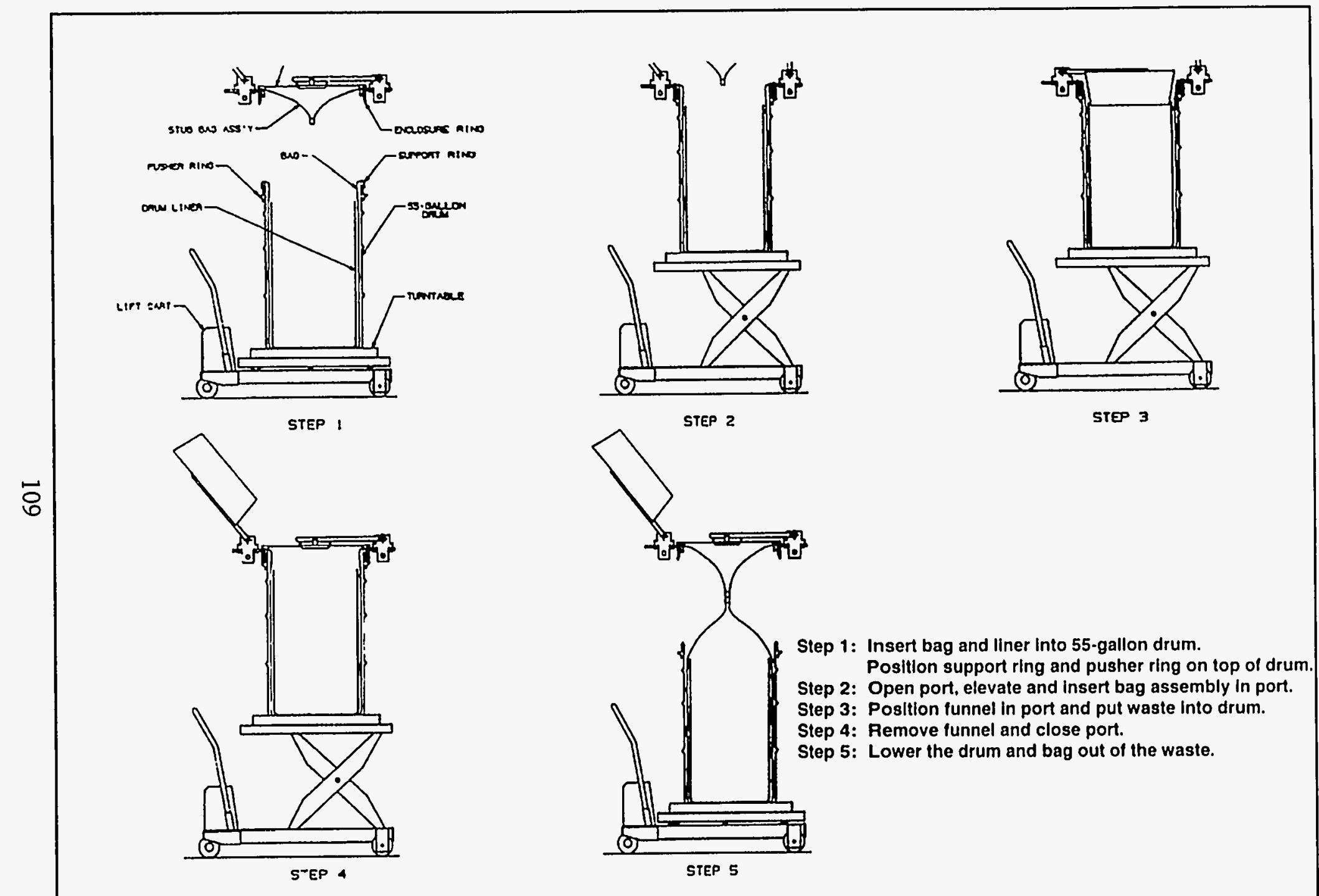

Fig. 35. CRL drum-out device operating procedures. 
Limited barrel unload tests were also performed. Project termination precluded additional development.

\section{CONCLUSIONS}

The activities described in this document describe the evolution of the design for a glove box facility for repackaging CH-TRU waste.

The results of these design activities have yielded significant progress in identifying options and solutions for the task of disposing of ORNL's CH-TRU waste. Specifically, we

1. characterized and quantified the risks and hazards associated with the ORNL CH-TRU drum inventory;

2. progressed significantly in compiling existing and relevant $\mathrm{CH}-\mathrm{TRU}$ inventory and radiological data into one applicable $\mathrm{PC}$ data base;

3. assessed WTPP-WAC requirements and plans in order to schedule ORNL's characterization, certification, and repackaging activities to support the WIPP-WAC Disposal Decision Plan;

4. advanced the facility/system design of two options to a level of maturity whereby advancement to the detailed design and procurement stage is possible;

5. benchmarked design options against INEL and ANLW designs;

6. incorporated operator experience by processing simulated drums in the mock-up facility; and

7. significantly advanced the development and demonstration of the critical bag-in/bag-out device with the candidate manufacturer.

\section{REFERENCES}

1. R. H. Cooper, Jr., C. E. DeVore, J. S. Ivey, W. A. Gabbard, and W. H. Miller, Jr., CH-TRU Waste Repackaging in the Irradiated Fuels Examination Laboratory, Metal and Ceramics Division, Internal Report (1994). 
2. F. J. Schultz, K. W. Haff, and D. E. Coffey, ORNL TRU Waste Drum Assay and Sampling Facilities: Operations Procedures Manual, ORNL/CF-83/253 (1994).

3. Browne, E., and Firestone, R. B., Table of Radioactive Isotopes, Wiley-Interscience, 1986.

4. Weast, R. C., Handbook of Chemistry and Physics, CRC Press, 1977.

5. Wang, Y., Handbook of Radioactive Nuclides, CRC Press, 1969.

6. Morgan, K. Z., and Turner, J. E., Principles of Radiation Protection, John Wiley \& Sons, 1967.

7. Recommendations on Limits for Exposure to Ionizing Radiation, NCRP Report No. 91, National Council on Radiation Protection and Measurement, 1987.

8. Transuranic Nuclides in the Environment, International Atomic Energy Agency, Proceedings Series, 1976.

9. Kunz, W. E., and Caldwell, J. T., Current Status of Multi-Isotopic Transuranic Waste Assay System, Los Alamos Report LA-UR-82-787, ANS Topical Meeting, Richland, Washington, April 1982.

\section{ACKNOWLEDGMENTS}

The authors would like to thank C. L. Dotson and J. D. Smith of the M\&C Division Technical Photography Group for their skillful preparation of the many figures in this report. The authors also thank A. C. Holder, K. R. Lively, S. M. Wilson and A J. Shelton for their dedication and patience in preparation of the manuscript. 